\title{
Intramedullaire osteosynthese van het femur
}

Citation for published version (APA):

Stapert, J. W. J. L. (1983). Intramedullaire osteosynthese van het femur. [Doctoral Thesis, Maastricht University]. Rijksuniversiteit Limburg. https://doi.org/10.26481/dis.19830916js

Document status and date:

Published: 01/01/1983

DOI:

10.26481/dis.19830916js

Document Version:

Publisher's PDF, also known as Version of record

\section{Please check the document version of this publication:}

- A submitted manuscript is the version of the article upon submission and before peer-review. There can be important differences between the submitted version and the official published version of record.

People interested in the research are advised to contact the author for the final version of the publication, or visit the DOI to the publisher's website.

- The final author version and the galley proof are versions of the publication after peer review.

- The final published version features the final layout of the paper including the volume, issue and page numbers.

Link to publication

\footnotetext{
General rights rights.

- You may freely distribute the URL identifying the publication in the public portal. please follow below link for the End User Agreement:

www.umlib.nl/taverne-license

Take down policy

If you believe that this document breaches copyright please contact us at:

repository@maastrichtuniversity.nl

providing details and we will investigate your claim.
}

Copyright and moral rights for the publications made accessible in the public portal are retained by the authors and/or other copyright owners and it is a condition of accessing publications that users recognise and abide by the legal requirements associated with these

- Users may download and print one copy of any publication from the public portal for the purpose of private study or research.

- You may not further distribute the material or use it for any profit-making activity or commercial gain

If the publication is distributed under the terms of Article $25 \mathrm{fa}$ of the Dutch Copyright Act, indicated by the "Taverne" license above, 


\section{Intramedullaire osteosynthese}

\section{van het femur}

\section{Proofschrift}

Ter verkrijging van de graad van doctor in de geneeskunde aan de Rijksuniversiteit Limburg te Mastricht, op gezag van de rector magnificus Prof. Dr. H.C. Hemker, volgens het besluit van het College wan Dekanen in het openbaar te verdedigen in de Aula van de Universiteit op vrijdag 16 september 1983, des namiddags te viex uur

door

Jouwert Willem Jacobus Lucas Stapert, geboren te St. Odillënberg. 
Promotores: Prof. Dr. J.M. Greep. Riflasuniversitelt Lilmburg, Maastricht.

Prof. Dr. H.A.J. Lemmens, R. jksuntversitelt Limburg, Mastricht.

Referenten Prof. Drs. B. Blnnendijk, Rijksuniversitelt Groningen, Groningen.

Prof. Dr. R.J.A. Gorls, Katholleke Universiteit, NHjmegen.

Prof. Dr. A.J. van der Linden, Rijksuniversiteit Limburg, Maastricht. 
2. HISTORISCH OVERZ ICHT VAN DE BEHANDELING VAN FEMURSCHACHTFRACTUREN

2.1. DE CONSERVATTEVE BEHANDELING

2.2. DE OPERATIEVE BEHANDELING

3. ANATOMIE 7

3.1. FEMURSCHACHT

3.2. MUSCULATUUR 7

3.3. VASCULARISATIE 8

3.3.1. De arteria nutritia 9

3.3.2. De periostale vaten 10

3.3.3. De epifysaire-metafysaire vatwoorziendng 10

3.4. DEFTNITIE VAN DE FEMURSCHACHT 11

4. BOTGENEZ ING $\quad 13$

4.1. BOTAAMMAAK 13

4.1.1. Botaanmaak door metaplasle 13

4.1.2. Botaanmak door osteoblasten u1t het periost 14

4.2. BOTGENEZIMG EN VASGULARISATIE 14

4.2.1. Botgenezing bif intramedullaire osteosynthese 14

4.2.2. Botgenezing bij cerclage 15

4.3. BOTGENEZ ING EN MECHANISCHE STABILTTEIT

4.3.1. Küntscherpen 18

4.3.2. Kaessmannper 19

4.3.3. Kaesswannpen in combinatie met cerclage 19

5. INTRAMEDULLATRE OSTEOSYNTHESE 21

5.1. INDICATIES GEHANTEERD BLJ DE KEUZE VAN HET TYPE INTRAMEDULIAIRE OSTEOSYNTHESE 21

5.1.1. Vorm van de fractuur 21

5.1.2. Locallsatie van de fracture in de femurschacht 21

5.1.3. Potentiële isthmus 22 
5.2. OREH VERSUS GESLOTEN REPOSITIE VAN DE FRACTUUR BIJ OSTEOSYNTHESE

5.3. TIJUSTIP VAN DE OPERATIE 26

5.4. PRE-OPERATTEVE VOORBEREIDING 26

5. 5. LIGGING VAN DE PATIENT

5.6. OPERATTETECHNIEKEN 27

5.6.1. Kuntacherpen 27

5.6.2. Kaessmannpen 32

5.6.3. Kaesmannen in comblnatle met cerclage 35

5.7. NABEHANDELING 35

6. BEGELETDENDE LETSELS

6.1. INLE TDING 37

6. 2. INDELING VAN BEGELETDENDE LETSELS 37

6.2.1. Algemeen begeleldende letsels 37

6.2.2. Begeleidende letsels die door hun localisatie het eindresultaat van de behandeling mogelijk beinvloeden $\quad 37$

6.3. INJURY SEVERITY SCORE 37

7. HET NA-ONDERZOEK

7. 1. INLELDING 41

7.1.1. Het opsporen van de patiënten 41

7.1.2. Procedure bif het na-onderzoek 42

7.1.3. Overleden patiënten 44

7. 2. ANALYSE VAN HET PATTENTENBESTAND 45

7.2.1. Leeftijd en geslacht 45

7.2.2. Pre-existente ziekten 46

7.2.3. Aard van het ongeval 47

7.2.4. Begeleldende letsels 47

7.2.5. Interval tussen ongeval en na-onderzoek 48

7.2.6. Vorm van de fractuur 48

7.2.7. Localisatie van de fracturr 49

7.2.8. Aard wan de osteosynthese 49

7.2.9. Opnameduur 50

7.2.10. Verloop van de consolidatie 52 
7.3. RESULTATEN 52

7.3.1. Anatomische resultaten 52

7.3.1.1. Afuijkingen in botkengte 52

7.3.1.2. Hoekstanden 53

7.3.1.3. Rotatie-afwikingen 54

7.3.2. Functionele resultaten 57

7.3.2.1. Looppatroon 57

7.3.2.2. Functie wan de knie 57

7.3.2.3. Motitetert van de heup 60

7.3.3. Complicaties 60

7.3.3.1. Infectie 61

7.3.3.2. Vertragade consolidatie 63

7.3.3.3. Blijuende klachten 64

7.3.3.4. Ktachten in relatie tot anatomische of functionete afwikingen en comptiatien 65

8. NIET INTRAMEDULLAIR BEHANDELDE FRACTUREN VAN DE FEMURSCHACHT 69

8.1. BEGELE IDENDE LETSELS

8.2. OPNAMEDUURR 70

8. 3. VERLOOP VAN DE CONSOLTDATTE 70

8.4. ANATOMISCHE RESULTATEN 70

8.4.1. Afwijkingen in botlengte 70

8.4.2. Hoekstanden 71

8.4.2.1. Afwijkingen in het frontale viak 71

8.4.2.2. Afwijkingen in het sagittate vlak 71

B.4.3. Rotatie-arwljkingen 72

8.5. FUNCTIONEEL RESULTAAT

8.6. COMPLICATLES

8.6.1. Infectie 73

8.6.2. Stoornissen in de consolidatie 73

8.7. COMBINATIE VAN GEGEVENS OVER PATIENTEN MET KLACHTEN, ANATOMISCHE AFWIJKINGEN EN COMPLICATIES

8.8. DISCUSSIE 74 
9. VOOR- EN WADEEL WHN DE VERSCHILLELDE METHODEN VAN INTRAMEDULIAIRE OSTEOSYMTEESE

9.1. HET PRE-OPERATIEVE ONDERZOER 75

9.1.1. DLagnose van pre-existente zlekten 75

9.1.2. Diagnose wan begeleldende letsels 75

9.1.3. Fysische diagnostiek 75

9.1.4. Röntgenonderzoek 75

9.2. PROBLEMEN BIJ DE INDICATIESTELLING

9.2.1. Küntscherpen 77

9.2.2. Kaessmannpen 78

9.2.3. Kaessmannpen in combinatie met cerclage 79

9.3. PROBLEMEH BIJ DE PRE-OPERATIEVE VOORBEREIDING 80

9.3. 1. Problemen bij het imbrengen en verzorgen van de draadextensie $\quad 80$

9.3.2. Problemen bij de verdere behandeling van de patiënt in tractie

9.3.3. Problemen in de onmiddellijke pre-operatieve fase

9.3.4. Problemen bij de voorberelding van de intramedullaire osteosynthese

9.4. PROBLEMEN BIJ DE OPERATIE

9.5. NABEHANDELING 89

10. BEHANDELINGSPROTOCOL VOOR FEMURSCHACHTFRACTUREN 91

10. 1. ATGEMFNE TOESTAND VAN DE PATTENT

10.2. WEKE DELEN LETSEL 92

10.2.1. Huldietsel 92

10.2.2. Vaatletsel 92

10.2.3. Zenumletsel 92

10.2.4. Splerletsell. 93

10.3. LETSEL VAN HET BOT 93

10.3.1. Plates van de fractuur in de femurschacht 93

10.3.2. Vorm van de fractuur 93

10.4. BEGELETDENDE LETSELS

10.5. CONCLUSIE 
11. SAMENVATTING

12. SUMMARY

13. LITERATUUR

101 



\section{Doelstelling}

Voor een ongevalspatiënt betekent een letsel wan het bovenbeen met een breuk van de femurschacht een bedreiging van zijn leven.

De gevaren van de eerste uren tot dagen zijn verbloedingsshock, vetembolie en Infectie. In een later stadium dreigt, wegens voorbijgande of blijvende invaliditelt, een langdurige onttrekking aan het arbeldsproces, maatschappelijke functies, studie en sportbeoefentng (Van Eden 1923, Tordolr 1945, Kintscher 1959, 1967, Dencker 1963, Blnmendijk 1969, Kootstra 1973). Een zorgvuldig afwegen van alle factoren, die van Invloed zijn op de medische zorg voor een ongevalspatient is van groot belang voor het verkrijgen van een goed behandelingsresultat. Het medisch handelen bij de eergte opvang, diagnostiek, therapiekevze, uiteindelljke behandeling en daarop volgende revalidatie, moet een goed gecoördineerd verloop hebben.

Voor een ongevalspatient is de juiste keuze wan een behandeling in relatie tot de begeleidende letsels en de verwonding van het bovenbeen doorslaggevend voor het eindresultaat.

De oefenstabiele osteosynthese wordt in de laatste decennia aangeprezen als de beste therapie (Gotzen 1983). Deze methode stelt de patiënt, als stimulans voor de genezing, in staat vroegtijdig spleren en gewrlchten te oefenen en voorkomt functieverlies. De vroege mobllisatie met korte opnameduur heeft nast medische ook belangrijke socimle en financiële voordelen. Uiteraard heeft een agressteve behandellng ook schaduwzijden door het operatierisico, het gevar van infectie en de kans op het ontstaan wan een pseudarthrose.

In de heelkundige kliniek van Ziekenhuis St. Annadal te Mastricht, zijn in de periode van 1967 tot 1976 op een enkele uitzondering na, alle patiënten met een niet pathologlsche femurschachtfractuur behandeld met oefenstabiele intramedullaire osteosynthese.

Drie vormen van intramedullaire osteosynthese zijn toegepast:

1. Küntscherpien

2. Kaessmannpen

3. Kaessmannpen in combinatle met cerclage.

Tex beoordeling van zowel de indicatiestelling als ook de gebruikte operatietechnieken, zijn de patiëntengegevens na-onderzocht.

Daarnaast zijn voor een klein aantal patiênten behandeld met vroeg functionele, niet operatieve therapie, de resultaten beoordeeld.

Het doel van dit onderzoek is an de hand van de ruin 15-jarige ervardng met de behandeling van femurschachtfracturen via het afwegen van alle risico's en voordelen, te komen tot een oordeel over de warde van intramedullaire osteosynthese.

Begeleldende letsels, pre-existente ziekten, leeft1j, sociale onstandigheden, plaats en vorm van de fractuur in de femurschacht en de anatomie wan de mergholte, bepalen de keuze van de behandeling.

Een zorgvuldige analyse van de ondervonden problemen tifdens de indicatiestelling en behandeling lefit, samen met een beschouwing van de ulteinde1 ljke resultaten, tot de aanbeveling dat intramedullaire osteosynthese als behandelingsmethode woor alle voorkomende fracturen van de femurchacht gebrukt kan worden.

De ervaringen opgedaan met het gebruik van de Kintscher- en Kaesmanncompresstepen hebben de grondslag gevormd voor de toepassing van nleuwe vormen van intramedullatre osteosynthese, die de madelen van de tot nu toe gebruikte technieken in mindere mate bezitten. 
Een prospecteve atudle op basis van deze therapieschema"s, kan in de toekont lelden tot protocollalr geneskund ge arobevelingen ter verbetering van de behandelingstesultaten. Deze studie is een aanzet om te komen tot een gestructureerde behandeling van de femurschachtfractuur in Nederland. 


\section{Historisch overzicht van de behandeling van femurschachtfracturen}

Verschillende Nederlandse onderwokers leverden in het verleden ex bij-m drage aan onderzoek van patiênten met fenurschachtfracturen. Van wen (1923) was een der eersten die de restverschjjnselen bij patienten met een femurfractuur onderzocht. Hij vond dat $25 \%$ van de patienten een pemanente invaliditeitsuitkering genoot, in een tijd dat de sociale wetgeving nog in de kinderschoenen stond.

Tordolr en Moys (1945) berichtten over de asteosynthese van 31 femurschachtfracturen met behulp van de Kintscherpen. Binnendijk en Ponsen (1969) publiceerden de resultaten van osteosynthesen bif 86 femurschachtfracturen met behulp van de A.0.-plaat. Kootstra (1973) beschreef in een proefschrift de Groningse ervaringen met 329 Eemurschachtfracturen, warvan $70 \%$ operatief werd behandeld.

Een der grootste series in de 1iteratur kwam uit zweden en bestond uit 1003 femurschachtfracturen die in een dissertatie werden beschreven door Dencker in 1963.

\section{1. DE CONSERVATIEVE BEHANDELING}

Hippocrates gaf vier eeuwen voor de jaartelling aanwijaingen voor de behandeling van femurfracturen. Naast het nut van imobllisatie wees hil op het belang van tractie tex voorkoming van botlengteverlies van het fenur. Femurfracturen werden in het verleden niet-operatief behandeld. De toepassing van het gipsverband door Mathijsen in 1852 betekende een verbetering in de conservatieve fractuurbehandeling. Een verdere ontwikeling was de invoering van het zweefrekverband (Metz 1904, Van Loon 1935, Spoelstra 1970, Kingma 1973). Skelettractie werd geintroduceerd door Stelnmann (1907) en verbeterd door KJrschner (1926) met de draadextensle. Bobler $(1945,1957)$ verrichtte fundamenteel werk op het gebled van de conservatieve fractuurbehandeling. In Engeland beschreef Perkdns (1958) een behandelingsmethode voor femurfracturen met tractie, watrbij een oefenbed vroegtijdig quadricepsoefentngen toestond. Door deze oefentheraple kon de opnameduur aamerkeli jk worden bekort.

In het verleden bestond de fractuurbehandeling uit repositie van de fractuur en langdurige immobilisatle van de gereponeerde fractuurfragmenten tot de consolidatie was voltooid. Aansluitend werd oefentheraple voorgeschreven, gericht op herstel van de functie.

Vanuit de V.S. wordt in de recente 1iteratuur de ontwlkkeling van nlet operatleve behandelingsmethoden gepropageerd, waatblj zeer vroege oefentherapie mogelijk wordt door van beugelapparatuur en spalken gebruik te maken. Mobllisatie in een vroeg stadium van de fractuurbehandeling makt het mogelijk effectlef te oefenen en hlermee een volwaardig functioneel herstel van het been te verkrijgen (Hardy 1976, 1982, 1983, Mc Coy 1976, Crotwe11 1978, Sarmiento 1981).

Deze vroeg functionele, nlet operatieve therapie, kont woor een groot deel tegemoet aan de boven beschreven nadelen van de klassleke conservatieve behandeling. De voorstanders van deze behandeling stellen (Sarmiento 1981), dat de opnameduur nlet langer is dan die van operatlef behandelde patiënten.

\subsection{DE OPERATIEVE BEHANDELING}

Hippocrates schrok er nlet voor terug een open repositle ult te voeren indien conservatieve methoden niet tot een bevredigend resultaat leidden. Met de Invoering van de asepsis na 1885, magel1jkheid tot shockbestrijding en narcosetechnlek, werd rond de eeuwwisseling chirurgie mogelljk. Lane 
(1914) stabliseerde Eracturen yoor het eerst met behulp van platen en achroeven. Lambotte (1913) introduceere de tixateur externe bij operathe fracturebehindeling.

Reeds vö́r de eeuwisseling werd intratuedullaire stabilisatie war fracturen verricht door Nicolaysen, Delbet en Lambotte. Delbet paste deze methode 1 in 1906 toe bij fracturen wan het collum femoris, terwil Lambotte in 1913 nast de collumfractur ook kleine botfragmenten met pennen fixeerde (Watson-Jones 1950).

De intrantullatre osteosynthese van het femur werd op grotere schaal verricht door Hey Groves. Hew Groves bracht 70 jaar geleden mergpennen in wa de trockantor major. Hyj gebrulkte drie soorten stalen mergpennen:

masileve ronde pennen, op doorsnede kruisvormige pennen en holle pennen met gater. Wet deze intramedullaire flxatle berelkte Hey Groves een zodanlge stabiliteit, dat aanvuliende matregelen om de fractuur tegen dislocatlie te beschermen, overbodig waren. Hey Groves kwam tot de overtuiging, dat massieve pennen de beste flxatle garanderen (Hey Groves 1916, 1918).

Inert metaal voor de vervaardiging van mergpennen was in de tijd van Hey Groves nlet beschikbaar, zodat wegens vroegtijdlge corrosie van het wel beschikbare metal, osteosynthese op grotere schall geen 1 ngang vond.

In de vroege geschiedenis van de intramedullaire osteosynthese werd naast stakl, ook biologisch material voor de vervaardiging van mergpennen gebrulkt. In 1917 werden experimenten verricht met pennen van ivoor, runderen menselijk bot (Hoglund 1917). Daar zij snel resorbeerden kon met deze pennen de stabiliteit niet lang genoeg worden gehandhaafd (Watson-Jones 1950).

Toen Smith-Petersen, Cave en Vangorder (1931) de inerte legeringen 18/8, 18/12 S.M.0. staal em witallium voor hun mergennen gingen toepassen, nam de interesse in de osteosynthese van fracturen toe.

Lambrinudi (1940) en Davis (Soeur 1946) verrichtten osteosynthese met behulp van Kirschnerdraden. Rush (1939) fixeerde fracturen met behulp van Stelmannse pennen die hij in de mergholte van het fenur bracht. De technieken warbij het osteosynthese materiaal de mergholte niet volledig apvulde, Ieidden niet tot de gewenste stabilfteit. Door de toepassing van dikkere mergpennen kon een betere stabiliteit van de fractuurelementen bereikt worden (Watson-Jones 1943).

Het inbrengen van mergpennen zonder de fractuur wrij te leggen, "het gesloten pennen", vond steeds meer opgang. Böhler $(1945,1949)$ werd, ondanks zijn voorliefie woot de conservatieve fracturbehandeling, een groot aanhanger van de gesloten intramedullalre osteosynthese. Het was Kintscher (1967), die in zijn boek uitvoerig de techniek van het inbrengen van een mergpen beschreef. Een groot indicatiegebied voor het gebrulk van zijn pen werd angegeven. Slechts kinderfracturen en de aanwezlgheid van geinfecteerde wonden in de nabljheid van fracturen, waren een contra-indicatie voor het gebrulk wan zilin techntek bij verse fracturen.

Kintscher paste mergpennen toe bij verse fracturen van femurschacht, trachantermasief, tibia, humerus, radius en ulna. De pseudarthrose van een pijpbeen was volgens kuntscher de beste indicatie voor het gebrulk van een mergpen. Ook gelnfecteerde fracturen met vertraagde consolidatie, werden door hem met een mergpen behandeld. Hij paste zijn pen toe bijosteotomieën, arthrodesen en de behandellng van pathologische fracturen. Al de door hem ontwikkelde technieken stoelden op de overtuiging, dat het operatief vrijleggen wan een fractur met de daaruit voortvloelende devascularisatie van het bot, vemeden diende te worden. Küntscher was daatom tegen open repositie bij de intramedullaire osteosynthese. 
Bij de beschouwing van kütscher's werk moet bedacht worden, dat zijn methode ontwikkeld werd onder moeilijke oorlogsomstandigheden, wet tekort aan verpleegkundigen, met de noodzak tot snel vervoerbar maken van oorlogsgewonden en met de onzekerheld over het feit hoe lang de patient lin het ziekenhuis nabehandeld kon worden. Namate de kintschermethode frequenter werd toegepast, werden in toenemende mate complicaties gemeld. Het werd duidelijk, dat de gevaren verbonden aan het gebruik van de küntscherpen niet onderschat moesten worden (Silth 1950).

Een belangrijk probleem bij de toepassing van de oorspronkelijke küntscherpen bleek de geringe weerstand van deze stabilisatiemethode tegen krachten die een ratatie ten gevalge hadden. Deze rotatie-instabiliteit was de reden, dat in de zestiger jaren pennen ontwikkeld werden, die rotatie niet toestonden. Men probeerde de pen meer howvast in de mergholte te geven door in afwijking van de klaverbladvormige doorsnede van de kütscherpen, een pen met stervormige af polygonale doorsmede te gebruiken. Zo ontstonden de Sampson-, Schneider- en de Hansen-Streetpen (Allen 1978, Heiple 1979, McMaster 1980). Ook het opboten van de mergholte warcloor de pen over een langer traject kon inklemmen betekende een verbetering, maar geen definitieve oplossing van het rotatieprobleem.

Een tweede nadeel van de Küntscherpen was, dat het indicatlegebled beperkt bleef tot fracturen van het middelste eenderde deel van de fenurschacht. Proximale en distale fracturen konden niet met de Kuntschemethode behandeld worden. Bovendien waren comminutieve fracturen en splraalfracturen ongeschikt voor de kintschermethode.

In 1968 ontwikkelde Küntscher de "Detensionsnagel", warbij het proximale en distale deel van de fractuur met dwarsschroeven aan de pen werden bevestigd. De operatietechniek was echter ingewikkeld. Het oorspronkelijk idee van Küntscher werd 1 n 1970 verbeterd door Klemm en Schellmann en verder vervolmaakt door Grosse en Kempf in Strasbourg met de "Verriegelungsnage1" (Klenm 1972). De röntgenbelasting bij het inbrengen van een dwarsschroef door het gat van deze intramedullalr gelegen grendelpen, werd door toepassing van een richtapparaat tot aanvardbare proporties teruggebracht. (Grosse 1978).

De "Arbeitsgemeinschaft für Osteosynthesefragen", bestaande uit ingenieurs, blologen en artsen (de A.0.-groep), ontwikkelde $\mathbb{i}$ in Zwitserland, aan het einde van de gestiger jaren een systeem van platen en schroeven ter behandeling van fracturen. Door de fracturelementen door middel van trekschroeven of het spannen van de plat te comprtmeren, ontstord een wolstrekte onbeweeg11jkheid 1 in de fracturspleet. Een drukbelasting van $2943 \mathrm{~N} / \mathrm{cm}^{2}$ werd door het bot verdragen zonder dat er necrosevorning optrad. Dit is 45 mall de druk warmee de band wan een middenklas auto op het wegdek drukt. Met deze door interfragmentalre druk verkregen onbeweegl1jkheid, werd primaire botgenezing nagestreefd (Perren 1969, Schenk 1977 ).

Het aambrengen van een compressieplat betekende een aansllag op de periostale vatwoorziening van het bot.

In 1966 ontwierp Kaessmann in Götingen, bewust van het hellzame effect van interfragmentaire compressie en de nadelen van vrijleggen van de fractuur, een intramedullaire compressiepen. Met deze pen behield hit het voordeel van gesloten intramedullaire osteosynthese, terwijl door het aambrengen van interfragmentalre druk een toename in stablliteit werd bereikt. De rotatiestabilitelt bij dwarse fracturen werd met deze methode verbeterd.

Het indicatiegebied kon met deze intramedullaire pen vergroot worden. De Kaessmannpen was dunner dan de Küntscherpen, zodat uitvorertg opboren van de mergholte achterwege kon blijuen (Kaes amann 1970). 
De Kaessmannen kon ndet toegepast worden bif comminutieve- en spiraalfracturen. Axiale druk bil deze fractuurvormen resulteerde in verkorting, warbif geen stablele fixatie werd bereikt. Lemeng (1970, 1975) vergrootte het toepasingsgebied door bij spiral-en cominutieve fracturen, de Kaessimannen in comblnatle met cerclagedraden te gebrulken.

Een blifwend probleem bll het gebruik van de Kaessmanpen was de technisch nlet eenvoudige operatie en de röntgenbelasting voor patieunt en operateur.

De voorstanders van de intramedullaire osteosynthese hebben thet oorspronkelifk idee van de compresslepen verder ontwlkkeld. Derweduwen (1979) ontwierp een compresslemergpen die de meeste nadelige elgenschappen van de Kaesimannpen $11 j k t$ te misgen en thans klinisch getest wordt.

Het ldeaal voor de toekomst lijkt een mergpen, die nlet verwljderd hoeft te worden, bestaande uit in vivo oplosbaar materiaal waarmee zowel compressie als rotatiestabliltelt gedurende fractuurgenezing bereikt kan worden (Kloppex 1981). 


\section{Anatomie}

\subsection{FEMURSCHACHT}

Het femur vertoont als langste pijpbeen van het menselijk 1lcham een antecurvatie. De ventrale convexe bulging warborgt een zekere elasticiteit bij het lopen en springen. De linea aspera met zijn lablum mediale en laterale, an de achterzljde van de femurschacht, dient voor de insertie van bovenbeensmusculatuur. De linew aspera heeft door zijn driehoekige vorm een "pijlerwerking" waardoor extra stevigheid ontstaat. Het labium mediale is een botkam die vanaf de trochanter minor aan de achterzljde, naar distaal verloopt naar de mediale eptcondyl van het femur. Het labium laterale is een botkam die vanaf de achterzijde wan de trochanter major aan de achterzijde naar distaal loopt, naar de laterale eplcondyl van het femur (Kunmer 1959).

De vorm van de mergholte is van belang bij de intramedullaire osteosynthese. Deze is op doorsnede vrijwel rond in het proximale deel van het femur (Böhler 1945) en meer driehoekig van voun distaal. In het sagittale vlak is de mergholte zandlopervormig (Hulskes 1980).

Bif jonge atletische personen wordt een nawwe mergholte gevonden met een gemiddelde diameter van 6 tot $7 \mathrm{~mm}$. Bij oudere mensen meent de dikte van de corticalis af en is de mergholte groter in diameter (Watson-Jones 1950). Bif het stljgen van de leeft1jd neemt de ventrale convexe butglng toe. De röntgenologische dichthell van het bot neemt af.

De gebleden met de grootste dichtheld van de botstructur $z i j n$ gelegen langs een rechte lifn die proximal door de ventrale, in het middengedeelte door de mediale en distaal door de dorsale cortex van het femur loopt. Via deze 11 jn wordt het femur bij het rechtopstaan belast. Met het stijgen van de leeftijd treedt de ontkalking wooral buiten deze zone op, waardoor zoveel mogelifk van de mechanische belastbararheld van het bot bl1jft gehandhaafd (Atkinson 1967).

\subsection{MUSCULATUUR}

De spieren van het bovenbeen $z 1 j n$ gelegen in een bindweefse $\mathbb{1}$ continuim en tonen aan hun periferle een koker van stevig bindweefsel, de fascla lata. De tractus iliotibialis is een lateral gelegen verstevigd deel van de fascla lata, dat samen met de musculus tensor fascla lata en een deel van de musculus vastus lateralis zorg draagt voor de verstaging van het femur aan de laterale zijde (Pauwels 1951 ).

Drie septa van bindweefsel verdelen het bovenbeen in drte compartinenten:

1. het extensoren compartiment, dat de musculus vastus lateralls, de must culus vastus hedialis, de rusculus vastus intermedius en de musculus rectus femorls, tezamen quadriceps femoris genoemd, bevat, met daarnast de musculus sartorius, die werkt als flexor van heup en knie en tevens abductie en exorotatie van het been bewerkstelligt. De museulus articularus genus werkt als extensor van de knle. De extensoren worden geinnerveerd door de nervus femoralis $(12,3,4)$.

2. het flexoren compartiment, dat de muscullus semitendinosus, de musculus semimembranosus en de musculus bicepe femorls bevat. De flexoren worden geinnerveerd door de nervus tiblalis (L4, 5; $S 1,2,3$ ), behoudens het caput breve van de musculus biceps femorts, dat geinnerveerd wordt door de nervus peroneus communis (LS, S1, 2 ).

3. het adductoren compartiment, dat de musculus pectineus, de musculus obturator externus, de musculus adductor brev1s, de musculus adductor longus, de musculus adductor magnus en de musculus gracilis bevat. De 
spleren worden geinnerveerd door de nervus obturatorius (L3, 4). De musculue pectinewo wordt gelnnerveerd door de nervus femoralls (L2, 3), termfl de rervag ischladicus (L4, 5; 51$)$ een deel van de musculus adductor magnus innerveert.

Aan het mediale deel van de linea aspera hechten de musculus pectineus, de musculus vastus medialis, de musculus adductor brevis, de musculus adductor magnus en de musculus adductor longus an.

Aan het labium laterale hechten de musculus gluteus maximus, de musculus blceps femorts, de musculus vastus lateralis en de musculus rastus intermedius an. De musculus vastug internedius en even boven de knie de musculus articularts genus hechten aan de voorzijde van de femurschacht aan. Aan de achteraljde hecht aan het planum popliteun een der 1 van de musculus gastrocnemlus an (figuur 1 ).

Elguur 1. Anatomile van het bovenbeen.

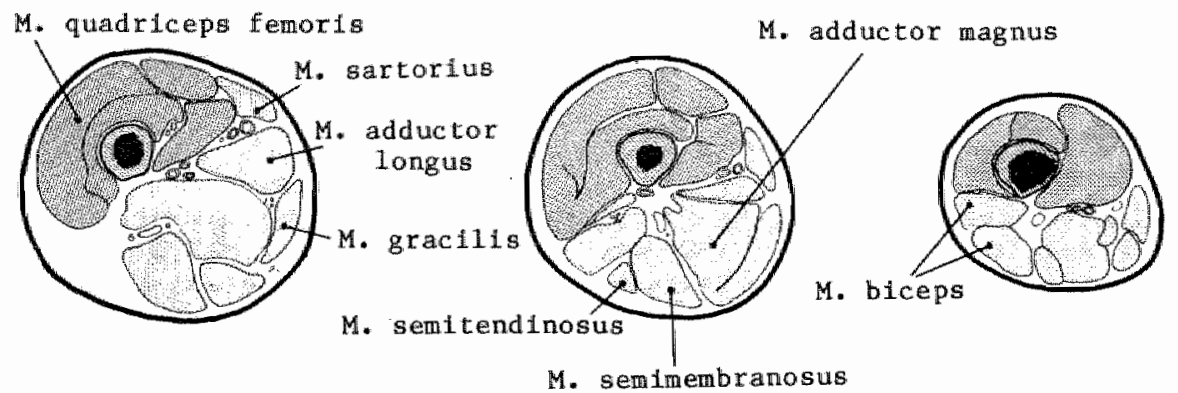

\section{3. VASCULARISATIE}

De bloedvoorzlening van het femur geschiedt voornamelijk vanuit de arteria profunda femoris. Een van de eerste zljtakken van deze arterie is de arterita circunflexa fenoris lateralis, die onder andere de bloedvoorziening van de extensoren verzorgt.

De arterla circumflexa femoris medialis voorziet de adductoren van bloed. Meer naar distaal geeft de arteria profunda femoris een drietal perforerende takken af, die door de aanhechting van de musculus adductor magnus heen de flexoren van bloed voorzien. Twee van deze perforerende takken voorzlen de blowvaten, die via een antal foramina nutrienta, gelegen nabij de linea aspera, de mergholte van bloed voorzten.

Aan de achterzijde van het bovenbeen bevinden zich op verschillende niveau anastomosen tussen de hierboven genoemde arteriën. Vam proximal nar distaal bestaan er anastomosen tussen:

1. de arterla circumflexa medialis femoris, de arteria glutea inferior en de arterla obturatoria uit de arteria iliaca interna,

2. de belde arterlae clmcumflexae en de eerste perforerende arterle,

3. deverschiliende perforetende arteriën,

4. de vierde perforerende arterie en opstijgende spiertakken vanult de arterin poplitea.

De arteria femoralis superficialis geeft in hagr verloop door het bovenbeen, vilak voor de intrede in het kanal van Hunter, de arteria descendens. genicularis af. Deze mediaal gelegen, afdalende tak anastomoseert met de afdalende laterale tak van de arteria clrcumflexa fenoris via takken aan de voorzijle van het femur. Ook hebben deze beide arterien via de mediale en laterale arteria genicularis superfor en inferior anastomosen met de 
arteria poplitea. Vanuit dit netwerk worden de distale delen wan musculus wastus lateralis, musculus vastus medielis en adductor magnus van bloed voorzien (figuur 2).

Eiguur 2. Vascularisatie van het fenur.

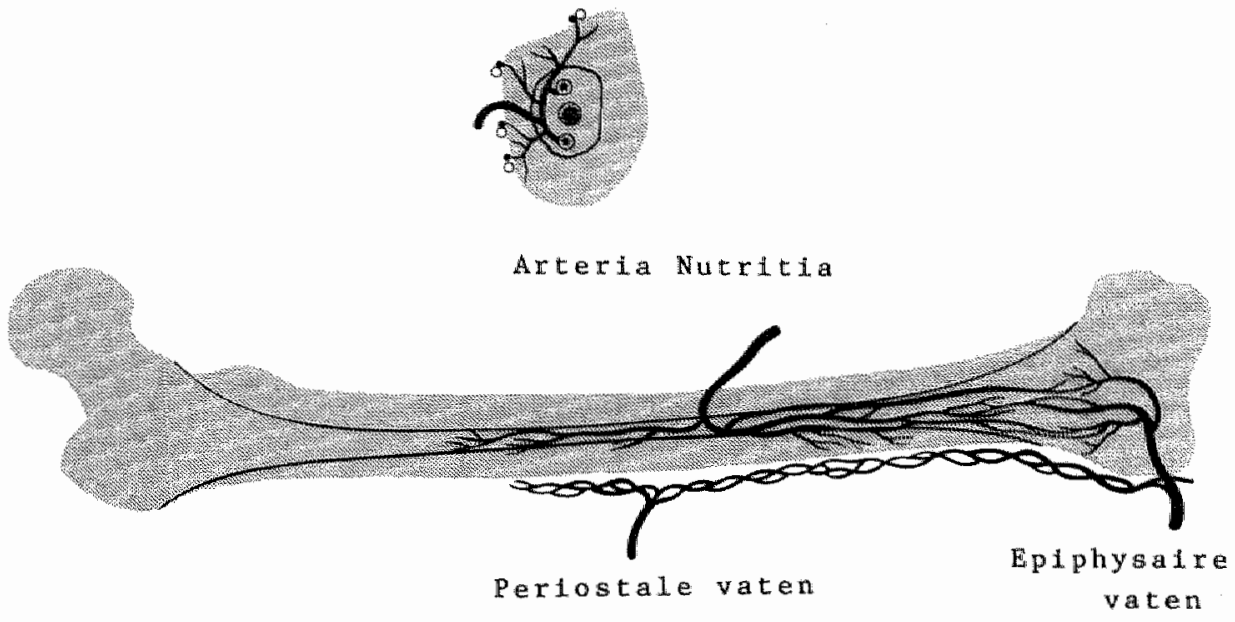

De bloedvoorziening van het femur is volledig vergelijkbaar met het vascularisatiepatroon van andere lange pijpbeenderen.

Er bestaan drie hoofdsystemen die zorgdragen voor de bloedvoorziening van de cortex: 1. de arteria nutritia, 2 . de periostale vaten en 3 . de epifysaire bloedvaten (Trueta 1964, Rhinelander 1968, Holden 1972, Von Hildebrandt 1979$)$.

3. 3.1. De arteria nutritia

Halverwege het femur treedt de arterla nutritia als tak van de arterla profunda femoris via het foramen nutritente de schacht van het femur binnen aan de achterzijde mabij het lablum mediale van de linea aspera. Soms $z 1 j \mathrm{~m}$ er meerdere foramina, verder distaal gelegen in de linea aspera.

Het foramen nutriënte geeft toegarg tot de mergholte via een van distal naar proximal schuin verlopend kanal van enige centimeters lengte. In de mergholte vertakt de arteria nutritia zlch in een of meerdere ram ascendentes en descendentes. Deze dragen zorg voor de vascularisatile van het beenmerg. Kleine takken dle straalsgewijs van binnen naar buiten de corticalis doorboren, verzorgen de vascularisatle van het binnenste tweederde gedeelte van de corticalis. Deze arteriën hebben een uitgebreld netwerk van anastomosen net de periostale vaten. Wordt bij volwassen dieren, de arteria nutritia onderbroken, dan kan er histologisch, micro-anglografisch en röntgenologisch geen necrose van de cortex worden aangetoond. 
3.3.2. De perlostale vaten

Het periost bestat ult twee lagen, een buttenste wezellaag en een binnenste cellaag.

Butten tegen de vezellagg $14 \mathrm{gt}$ een dicht netwerk van venen en arteriën, die worden gevoed vanuit de omrlingende weke delen. In de vezellaag bestaat een ultgebreid raster van arteriën en venen met een longitudinale rangschikking.

De cel- of osteogenetische laag bevat capillairen die naar de cortex lopen. Er bestaat een nauwe samenhang tussen de bloedvoorziening wan het periost en de daar tegenaan gelegen spieren. De bloedvaten naar het periost lopen loodrecht op de lengte-as van het bot.

3.3.3. De eplfysaire-metafysal re vaatwoorzienting

Vanult de periferie dringen een groot aantal vaten de metafyse wan het bot binnen. Een deel van de vaten loopt aan de buitenzijde en makt verbinding met thet perlostale vatnet. Een ander deel anastomoseert met de medullaire vaten. Bif onderbinden van de arterla nutritia treden nauwelijks waarneembare veranderingen an de cortex op, dankzij de verbindingen met het epifysadre-metafysalre vaatnet. Wordt de arteria nutritia samen met de metafysalie vaten onderbroken, dan ontstaat er necrose van het binnenste tweederde deel van de cortex. Deze necrose is bij het proefdier veel ultgebrelder, Indlen de epifysair lijnen niet gesioten zijn. In de normale cortex bestaan veel anastomosen tussen medullaire en periostale vaten. In deze anastomosen overheerst een van binnen naar buiten gerichte bloedstroom (Brookes 1961).

Figuur 3. Fenurschacht.

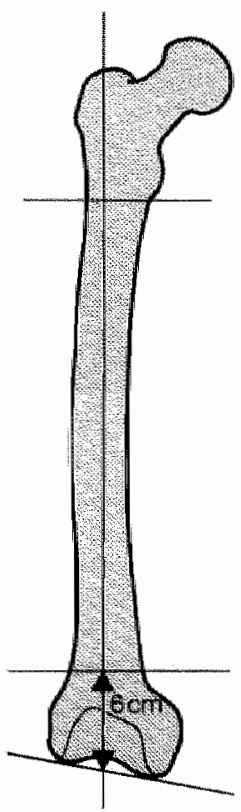

Bif de beschadigling van de circulatie door een fractuur, draalt de nomale centrifugale stroomrichting van het bloed in de cortex om en nemen de perlostale vaten de voeding over (Pfister 1979, Stiumer 1980).

De schacht van het femur is wat zijn bloedvoorzienling betreft dus afhanke$11 \mathrm{jk}$ van de drie woonoemde vaatsystemen, die onderling weer duldelifk anastomosen vertonen. De veneuze afvlloed geschledt via venen die met de 
arterien meelopen. Centrad in de mergholte $1 \mathrm{lgt}$ een grote centrale veneuze sinus.

\subsection{DEF INITIE VAN DE FEMURSCHACHT}

In navolging van verschillende auteurs (Carr 1958, Dencker 1963, Kootstra 1973) is het begrip femurschacht zo nauwkeurig mogelifk gedefinieerd om onderlinge vergelljking van diverse series femurfracturen mogelijk te maken. Voor de begrenzing van de femurschacht worden röntgenologische criterla aangehouden. Hiervoor kan gebruik worden gemakt van een voor/achterwaartse röntgenopname van het femur.

In deze studle wordt als proximale begrenzing van de femurschacht de lijn genomen die langs de onderrand van de trochanter minor loopt en loodrecht staat op de lijn getrokken van de top van de trochanter major naar het meest proximaal gelegen deel van de fossa intercondylica. Als distale begrenzing van de femurschacht wordt de 1 if jn genomen die op $6 \mathrm{~cm}$ afstand van het meest distale gewrichtsvlak der femurcondylen loopt en loodrecht staat op de voornoemde lengte-as van het bot (figuur 3). 



\section{Botgenezing}

\section{1. BOTAANMAAK}

Over de wijze waarop nieuw bot ontstat, bestat geen uniforme opvatting. Twee theorieèn kan men onderschelden:

1. de metaplasie-theorie warin botaanaak wordt verklaard door inductie,

2. de osteoblastische theorie die uitgat van periostale callusvorning*

4.1. 1. Botaanaak door metaplasie

Aanhangers van deze theorie menen, dat mesenchymale cellen onder invloed van een prikkel differentlëren naar botvomende cellen. Over de arad van de prikkel nodig tot botvorming bestaan verschillende opvattingen. Enerzijds bestaat de mening, dat bot gevormd wordt onder inwloed van een chemische of humorale prikkel. Daar tegenover staat de opvating, dat dtt proces geschledt door mechanische prikkels.

Kiintscher (1957), als aanhanger van de theorie, dat chemische prikkels botvorming induceren, onderscheidt in zijn studie over callusvorming an de hand van dierproeven en observaties bij patienten twee fasen:

1. het ontstaan van een mesenchynale weefselproliferatie ten gevolge wan ontsteking in het gebied van de fractur,

2. differentiatie van het mesenchymale weefsel in bot.

Kintscher ageert fel tegen de opvatting, dat mechanische krachten de botvorming induceren. Volgens hem verstoren mechanische krachten juist de botvorming. Dat botaanmaak inderdaad zonder mechanische pxikkel kan plaatsvinden is te zien bjjectopische botaanaak in weef sels die niet bij het skelet horen (Huggins 1931, Heinen 1949).

Kember (1960) toonde met een H3-thymldine labeling techniek an, dat mesenchymale cellen een ontwikkeling nar osteoblasten kwnnen doormaken. Deze mesenchynale cellen stammen af van het reticulo-endotheliale systeem Coberdalhoff 1947, Trueta 1962, Urist 1965, Friedenstein 1968, Pritchard 1972).

In nicroscopisiche en electronenmicroscoplsche preparaten laat Sarmiento (1981) zjen, dat osteoblasten en osteoclasten samen met ingroeiende cap11lairen naar de fractuur toe migreren. Botanmak begint in de best gevasculariseerde gebieden van de fractuur, dus meestal in te periferie van de callus.

Urist en Strates $(1970,1974)$ menen, dat botammak wordt geinduceerd door eidotiten ult de botmatrix.

Als anhanger van een mechanische prikkel tot botaanmak publiceert Roux (1895, 1912) de theorle, dat trekkrachten collageenvezels doen ontsaan, schuifbewegingen kraakbeen en hydrastatische druk bot.

ook Krompechex (1956, 1958) gelooft in het mechanische model hoewell hij stelt, dat kraakben onder invloed wan hydrostatische druk ontstat.

krompecher wakt onderscheid tussen desmogene en chondrale osificatie naast primaire anglogene botvorming. Dit laatste geschiedt in een mechanisch volstrekt neutraal milieu, zoals in schedelbeenderen, of lin een mechanisch stablele fractuur.

Bassett (1962) bestudeert botvorming in vitro aan de hand van weefselculturen van embryonale asteoblasten. Hij toont aan dat Indlen een compacte osteoblastencultuur in een milieu met $35 \% a_{2}$ wordt gekweekt, er uit de cellen botweefsel ontstaat, terwijl onder dezelfde omstandigheden bij $5 \%$ $0_{2}$ kraakbeen wordt gevornd. Wordt de cultuur niet in gecontraheerde compacte toestand, maar onder strekbelasting gekweekt dan ontstaan in een milieu met $35 \% \mathrm{O}_{2}$ fibroblasten en collagene vezels. Deze experimenten 
tonen alan, dat mechanlsche lnvioeden en veranderingen in het voedingsmedium bepalend zijn voor de manier warop een cultur van osteoblasten differentiert nar bindweefsel of bot.

\subsubsection{Botalanaak door osteoblasten uit het periost}

Het ignalisecen van botaanmak in het perlost nabij een fractur is aanlefding geveest tot het ontstaan van deze theorle.

Acht ur na een fractur is mitotische activiteit warneembaar in de cellaag, of osteogenet 1 che $1 \mathrm{aag}$ van het periost. In deze door prollferatie verdikte cellaag worden veel osteoblasten en capillalren aangetroffen (Tonna 1962).

Sevitt (1981) $1 \mathrm{~s}$ er van owertulgd, dat de snelheid warmee osteoblasten in het verdikte perlost ontstaan, wijst op het bestaan van een ander mechanisme. Voor osteogenese door inductie is namelijk een langere periode noodzakelijk.

Geen van belde theorleën kan een complete verklaring geven voor de verschillende verschijnselen wargenomen bij botaamaak. Zij vullen elkaar wel goed aan en kunner dan ook in onderlinge samenhang gebruikt worden (Van den WLdenberg 1982).

\section{2. BOTGENEZ ING EN VASCULARISATIE}

Zoals weergegeven in hoofdstuk 3 (figuur 2), worden lange pijpbeenderen vila drie wegen van bloed voorzien: het medullaire systeem, de periostale vaten en de eplfysalre-metafysaire vaten.

\subsubsection{Botgenezling bij intramedu1laire osteosynthese}

Göthman (1960, 1961) toont met stereomicro-anglografische technieken aan, dat tien dagen na het inbrengen van een mergpen in een konijnetibia vanuit het periost en de niet beschadigde delen van het intramedullaire vaatsysteem, revascularisatie van de cortex optreedt, die rond de vierde week de maximale onvang bereikt.

Blf Mangabey-apen toont hif aan, dat na het inbrengen van een mergpen, in de weke delen rond de fractuur een sterke toename van het aantal bloedvaten optreedt, en dat vanuit deze bloedvaten tot op grote afstand van de fractuur het perlost en het gebied van de fractuur wordt gerevasculariseerd.

Trueta (1955) beschrifft, dat na het inbrengen van een pen in de mergholte vam de radius van een konjun, necrose van het blnnenste tweederde van de cortex optreedt. Danckwardt-Lilileström (1970) vindt, dat door het opboren van de mergholte bij konifnen, \# $20 \%$ van de cortex gedevasculariseerd wordt. Bimen drie vier weken treedt een duidelifke revascularisatle op. Indlen zodanig wordt opgeboord, dat de door het opboren veroorzaakte drukverhoging in de mergholte verminderd wordt, is de necrose van de cortex beduldend minder.

Uit het voorafgaande blijkt, dat opboren een niet te verwaarlozen trauma voor de corticale clrculatle betekent, door ernstige beschadiglng van de medullalre vaten. Na 6én week treedt revascularisatle op, die na ongeveer vler weken voltoold 1s. Meer recent Dults onderzoek toont aan, dat de cortex zowel wan ult de mergholte als vanult de omringende weke delen gerevasculariseerd kan worden, aangezlen de nilet beschadigde intramedullaire vaten zeer snel een bifdrage aan de revascularisatie leveren (Schweiberer 1970, Rhinelander 1973, Ettel 1980, Kessler 1983).

Het herstel van het binnenste deel van de cortex na intramedullaire osteosynthese geschiedt nlet alleen door ingroel van bloedvaten vanuit de mergholte of vanut de periferie. Veeleer is er in het centrale deel van de cortex sprake van een afbraak en wederopbouw van botweefse1. Een zelfde 
verschijnsel wordt wargenomen onder osteosynthese platen. Het $11 \mathrm{jkt}$ ndet warschijnlijk, dat deze opbouw van bot optreedt door een verandering in de mechamische belasting van het bot ten gevolge van de aanwezigheid van de intramedullaire krachtendrager (Pfister 1983).

\subsubsection{Botgenezing bij cerclage}

Cerclagedraden worden reeds lang toegepast als enige of in combinatie met andere osteosynthese technieken. Arnesen (1951) meldt in een serle van 34 patiënten én spontane fractuur en é́n geval van botresorptle rond de draden. Olsson (1949) beschrifft een serle van 44 patiênten, warbij in negen gewallen necrose rond de draden wordt gezlen. In drie gevallen heeft dit aanleiding tot een spontane fractuur gegeven, Huwljler (1956) en Leemann (1957) zijn ervan overtuigd, dat de problemen bij het gebruik van cerclagedraden niet veroorzaakt worden door de draden zelf, maar te wijten zijn aan de geringe stablitteit die berelkt wordt lndien de osteosynthese uitsluitend uit cerclage bestaat. Charnley (1974) wijst he gebrulk van cerclage af. Evenals Danckwardt-Lillieström (1973) beschrijft ook Winquist (1980) goede resultaten van de combinatie cerclage en intramedullalre osteosynthese. Hij flxeert grote losse fractuurfragmenten met behulp van cerclagedraden. Aangezlen het verloop van bloedvaten loodrecht op de lengte-as van het bot kenmerkend is voor periostale callus, zal een extraperiostaal aangelegde cerclagedraad weinig nadelige invloed hebben op het vascularisatiepatroon (Rhinelander 1968).

In een dierexperiment warbij de doorbloeding van het bot gemeten is met een isotopenscan, kan door stöhrer (1972) geen nadelige Invloed van het aambrengen van cerclagedraden op de vascularisatie van het bot worden aangetoond.

\subsection{BOTGENEZING EN MECHANISCHE STABILITEIT}

De 1 iteratuur worden aangaande de stablifteit van de fracturrelementen ten opzichte van elkaar zeer verschillende opvattingen gehuldigd. Enerzijds wordt door auteurs absolute mechanische stabiliteit van de fracturelementen onontbeerlijk geacht, anderzijds wordt zelfs zonder interne fixatie van fractuurelementen vroege mobilisatie en partiëel belasten met behulp van een koker om het bovenbeen en beugelapparatuur aangeraden.

Absolute stabiliteit wordt gepropageerd door Küntscher (1957), Hutzschenreuter (1969), Matter (1975), en Müller (1977). Zij doelen op wolstrekte onbeweeglifkheid van de fractuurfragmenten ten opzichte van elkaar, verzekerd door interfragmentaire compressie. Met grote stabilitelt wordt primalre botgenezing door uitgroel van osteonen die de fractur overbruggen, nagestreefd (Allgöwer 1963).

Röntgenologisch zichtbare periostale callus is een teken van instablitelt en dus van een onvolkomen uitgevoerde osteosynthese (Wieser 1963).

De stabliteit die met een bepaalde osteosynthese bereikt wordt, kan aan de hand van proefmodellen onderzocht worden. Het vergelijken van de resultaten is niet mogelijk wegens verschillen in proefopsteliing bij verschillende typen osteosynthesen.

Diehl (1976) onderzoekt de buigbelasting van het femur onder versch11lende omstandigheden. Bij partiëel belast lopen, waarbij de kracht warmee belast wordt $98 \mathrm{~N}$ groot $1 \mathrm{~s}$, bedragt de bulgbelasting 200 tot $1200 \mathrm{Ncm}$.

osteosynthese van het femur met een compressieplaat, minimall drie trekschroeven of een fixateur externe met uitwendig frame gelegen in éér vlak aan beide zijden van het bot, garandeert voldoende stabllitelt van de fractuturelementen om een patiënt partiëel belast te moblliseren. Een femur van een patiënt in narcose ondergat bij onbeschermd optillen wan het been door de afwezhgheld van spierwerking een grotere buigbelasting (2500 tot 
3600 Nem. Indien onder deze omstandigheden voldoende stabilitelt moet woten verktegen, kan deze slechts door een compressieplat af, in het geval van een spiraletactuur, door drie trekschroeven worden bereikt. Cerclagedraden, mergpen en fxateur externe laten altijd bewegingen in de fractur toe. Een Kuntecherpen van voldoende afmeting biedt grote weerstand aan buigbelasting, maar houd altijd het nadeel wan beweging in de fracturipleet.

Osteosymthese met een Kintscherpen garandeerd weinig rotatiestab11Hteit. Lindahl (1962, 1964) en Van Straaten (1981) hebben de kracht berekend, die nodig is bij dwarse en schulne fracturen om $1^{\text {* }}$ rotatie te verkrijgen bij verschillende osteosynthese vomen. De gegevens van deze onderzoekingen zijn weergegeven in cabel. 1.

Tabel 1.

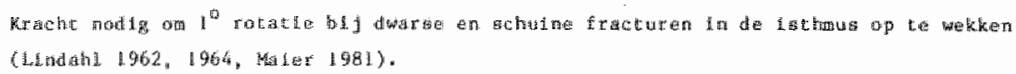

\begin{tabular}{|c|c|c|}
\hline fntact ferat: & & $128 d_{6} \quad x$ \\
\hline 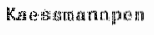 & 1177 N compressie & $392 \mathrm{ANCm}$ \\
\hline Künegenderpon & & 58 Nem \\
\hline patat & & 372 sem \\
\hline
\end{tabular}

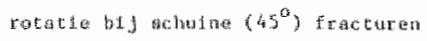

Lntast fonut

$12944 \mathrm{Ne}$

Katostanam/cerel age

9.

Kithe stheren

5.9 Nete

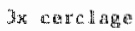

32 Nen

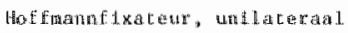

$75 \mathrm{Nem}$

y traksehrowen

$261 \mathrm{Nen}$

Utt tabel 1 blijkt, dat een Kintscherpen in vergelijking met een plaatosteosynthese en een Kaessmannpen, rotatiekrachten minder goed controleert, zowel bij dwarse als bij korte schulne fracturen.

Kenpf (1978) bestudeert de verandering van rotatiestabiliteit blj gebruik van een Küntscherpen, indien een fractuur door middel van pennen met verschillende dlameter wordt gefixeerd. Hij berekent het torsiemoment, dat nodig is om en met een Kintscherpen gestablliseerde femurfractur plasthsch te vervormen. Deze gegevens zijn weergegeven in tabel 2.

In tegenstelling tot Kïntscher denkt Kempf, dat de rotatiestabiliteit bij toepassing van de kuntschernethode niet verkregen wordt door de clrculalre elastische inkleming van de pen in de mergholte, maar door de wrijuing tussen pen en bot, die ontstat wanneer de rechte pen in het gebogen kanall van de mergholte wordt gedreven. Bij opboren wordt het mergkanaal steeds rechter zodat de Küntscherpen steeds minder zal inklemmen.

Kempl makk aannemelijk, dat verder opboren bij gebruik van toenemende pendikte geen verbetering en zelfs een total verlles van rotatiestabiteit betekent (tabel. 2). Ook de constructe van de originele kintscherpen makt deze, wegens de doorlapende sleuf an de dorsale zijde van de pen, weinig bestand tegen ratatiekrachten. Zonder sleuf zou de pen $56 x$ meer weerstand tegen rotatie bieden (Kempf 1978). 
Tabel 2.

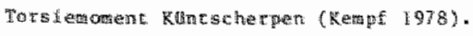

\begin{tabular}{|c|c|}
\hline aluater pen & $\begin{array}{l}\text { corsiemckent plaste isetye } \\
\text { vervorming }\end{array}$ \\
\hline 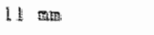 & $412 \mathrm{NCH}$ \\
\hline $12 \tan$ & $647 \mathrm{NCE}$ \\
\hline 13 & $412 \mathrm{Nom}$ \\
\hline $14 \mathrm{men}$ & $0 \mathrm{Nem}$ \\
\hline 15 แล⿻ & Q $\operatorname{Sen}$ \\
\hline
\end{tabular}

Bij de A.0.-pen en de grendelpen ontbreekt daarom de sleuf in het proximale deel van de pen. Een belangrijke toename van rotatiestabllitelt wordt: verkregen door het plaatsen van dwarsschroeven door pen en bot (figuur 4 ).

Figuur 4. Grendelpen.
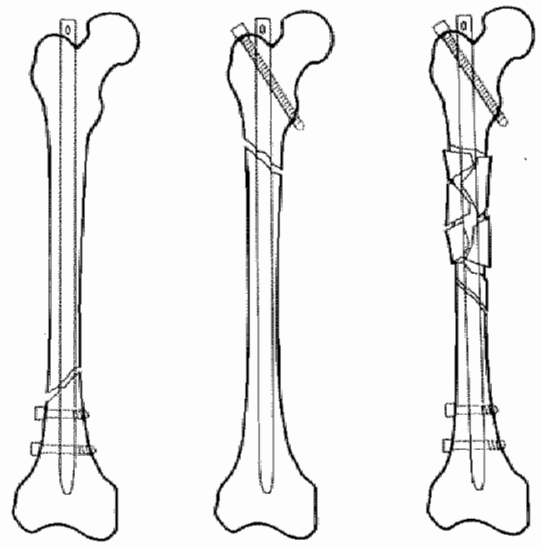

In tabel 3 zijn de torsiemomenten weergegeven die nodlg zijn om een osteosynthese van het femur met een grendelpen plastisch te vervormen.

Tabel. 3 .

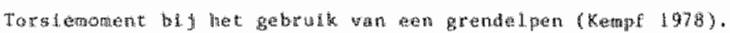

\begin{tabular}{|c|c|}
\hline 13 กตร & 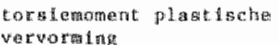 \\
\hline
\end{tabular}

Uit dit overzicht van een aantal onderzoekingen blijkt, dat zudver mechamisch gezlen, de Küntscherpen weinig rotatiestabllitelt biedt. De kaessmannpen heeft, ten opzichte van de Kütscherpen door het aanbrengen van compressie bij dwarse fracturen of compressie en cerclage blj schulne fracturen, zesmaal meer rotatiestabiliteit. Proxlmale en/of distale vergrendeling doet de rotatiestab111teit sterk toenemen. 
Jörgensen (1977) verricht bij 40 patiënten metingen om de vervormbarheid van de fractur in de verschllende stadia van de fracturgenezing na te gaan. Hij komt tot de conclusie, dat er van voldoende stabiliteit bij flikatle van fracturen gesproken kan worden, indien bij buigbelasting van

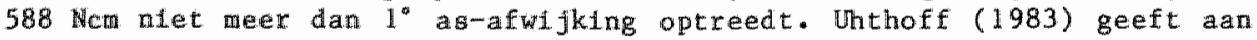
de hand van een onderzoek naar de fractuurgenezing bij honden aan, dat een munder rligide vorn van interne flxatle en een vroegtijdig verwijderen wan de plat, de fracturgenezing bevorderd en de stevigheid van het bot ten goede komt.

Onder invloed van de juridische consequenties verbonden aan de complicatles wan operatleve ingrepen, is in de laatste jaren in de V.S. een tendens waarneembar, die de nadruk legt op conservatleve behandeling.

Het vroegtijdig bewegen en herstel van functie staat duidelijk op de voorgrond bij deze niet operatieve behandeling van fracturen.

Sarmilento (1981) beschrijft de resultaten van een vroeg functionele behandeling blj 733 tibla-, 38 tibiaplateau-, 273 femur-, 156 pols-, 250 ulna-, 45 humerus- en 85 radiusfracturen. Hij 18 van mening, dat de massalle perlostale callusvorming die geinduceerd wordt door beweging tussen de fractuurfragmenten, mechantsch superieur is aan de callusvorming bij absolut stablel gefixeerde fracturen.

Het gebruik van Enderpennen, wan een fixateur externe, wan koolstofveze1platen en van de Küntscherpen blj de operatieve fractuurbehandeling heeft eveneens, ondanks de elastische niet volstrekt nechanische stabiele osteosynthese ultstekende resultaten opgeleverd (Pankovich 1981 , Wang 1981, Mister 1983, Unthoff 1983).

Het belang van mechanische stabilitelt bif fracturbehandeling is dus onderwerp van veel discussie.

4.3.1. Küntscherpen (figuur 5)

Bij osteosynthese volgens het Küntscherprincipe wordt stabiliteit door de elastische inklemming van een Kïntscherpen in de mergholte van het femur berefkt (Küntscher 1967). De pen is krachtendrager en moet daarom een diameter hebben van 13 a $14 \mathrm{~mm}$. Dow de grote wrifving tussen pen en bot, zowel proximaal als distaal van de fractuwr geeft de Küntscherpen stabi1 itelt.

Figuur 5. Kïntscherpen
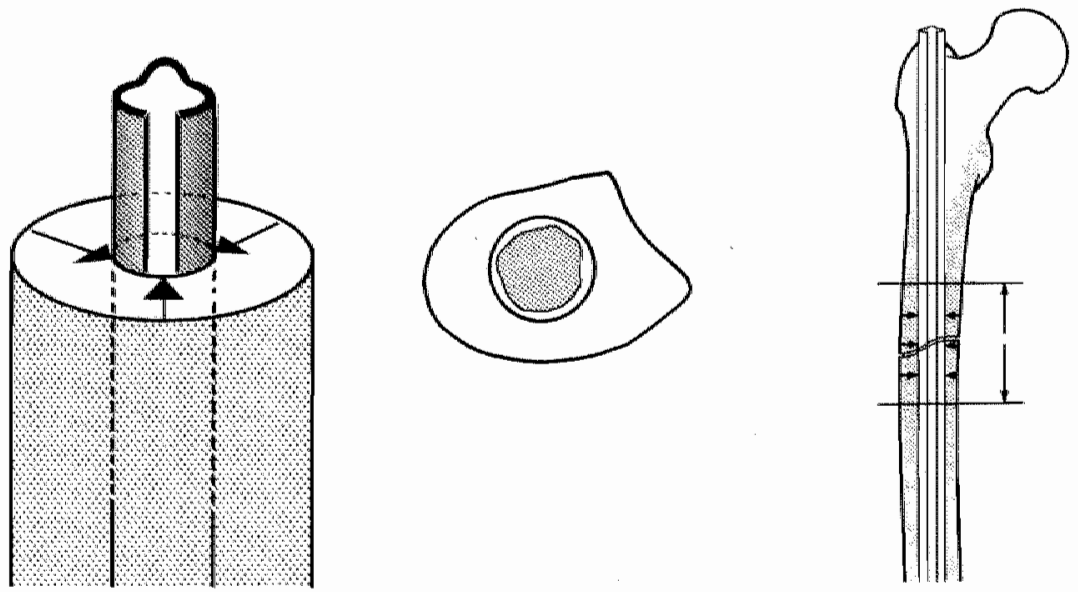
De wrijuing tussen bot en pen ontstad op twee manieren:

1. de circulaire inkleming van de elastische pen in de opgeboorde mergholte. Deze inkleming is door een juiste keuze vam boor en pendlameter woorspelbaar.

2. het contact, dat tussen bot en pen ontstat, wanneer een recht 11 cham in een gebogen kanal gebracht wordt. De hierdoor verkregen fixatie kan vóбr de osteosynthese moeilijk ingeschat worden.

Kempf (1978) hecht aan deze laatste worm van inkleming van de pen in de mergholte meer waarde dan aan de circulalire inklemming die door Küntscher (1967) als zeer belangrijk wordt beschouwd.

De indicatie voor het gebrulk van de küntscherpen zal worden besproken in hoofdstuk 5.1 .

4.3.2. Kaessmannpen (figuur 6)

De stabiliteft b1j het gebruik van de Kaessmannpen ontstat door interEragmentaire compressie (Kaessmann 1970). De Kaessmannen wordt over een voerdraad met een oog aan het eind (de spandoorn) in de mergholte gebracht. Met een van lateraal naar mediaal lopende schroef door bot en oog van de spandoorn, wordt het distale fracturfragment an de spandoorn bevestigd. Bovenop de pen wordt, om de spandoorn heen, een anker aangebracht. Vervolgens wordt de spandoorn samen met het daaraan verbonden distale fragment, met behulp van een speciaal instrument, naar proximaal getrokken, waardoor compressie tussen de fractuurfragmenten ontstaat. Het anker wordt met een dwarsschroef vastgezet en de spandoorn afgeknipt. Op deze manier wordt een stablele vereniging bereikt tussen bot en osteosynthese materiaal. Het bot blijft, in tegenstelling tot een osteosynthese met behulp wan een Kintscherpen, krachtendrager. De dianeter van de Kaessmannpen kan hierdoor geringer zijn, zodat met een dlameter van 10 mm kan worden volstaan. De indicatie voor het gebruik van de Kaessmannpen wordt besproken in hoofdstuk 5.1 .

Figuur 6. Kaes smannpen.

Figuur 7. Kaessmann/cerclage.
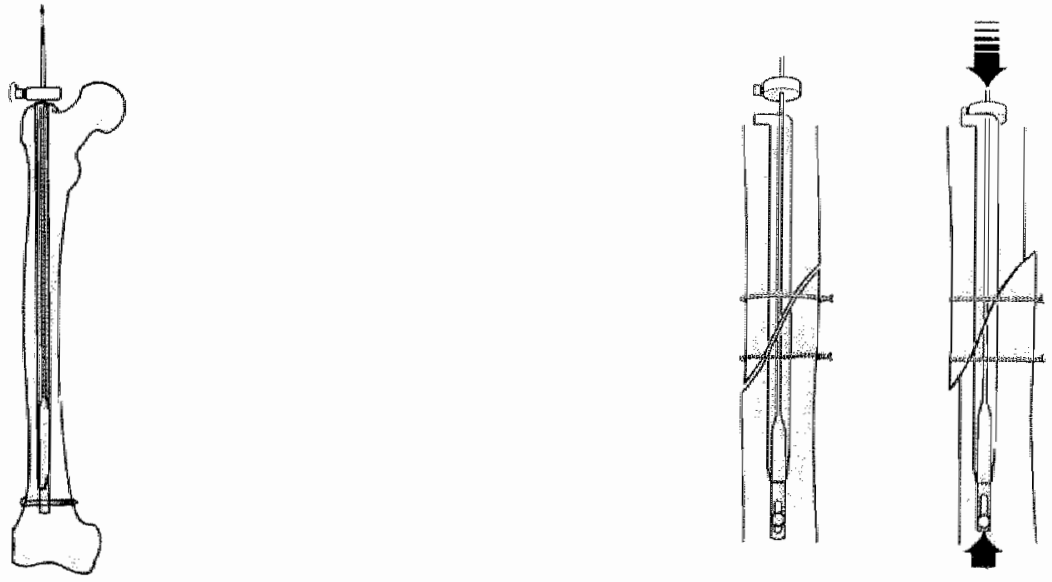

4.3. 3. Kaessmannpen in comblnatle met cerclage (figuur 7)

aok bij deze methode wordt stabiliteit bereikt door interfragmentaire campressie. Compressie in de lengte-as van het bot veroorzaakt bif spliral- 
en comminutieve fracturen verkorting, maar geen stablliteit. Lemmens (1970, 1975) comblneert de kaesmannpen daarom met cerclagedraden. Bif spiral- of cominutieve fracturen wordt de fractur met minimale beschadiglng van het perlost gereponeerd en gefixeerd met cerclagedraden. Na anbrengen van cerclagedraden ontstat door axlaal gerlchte compressie een expansledrang van de fractuurfragmenten. Deze expansledrang wordt door de cerclagedraden opgevangen, zodat een zeer stablele constructie ontstaat. ook hider 1 is het bot de krachtendrager. De indicatie voor het gebruik van Kaesmann/cerclage wordt besproken in hoofdstuk 5.1 . 


\section{Intramedullaire osteosynthese}

Bij beschrijuing van intramedullajre operatietechiaken wordt gebrulk genaakt van de aanwjzingen zoals die gegeven zijn door kintscher (1967), Kaessmann (1970), Van Straaten (1974), Miller (1977), Lemmens (1981) en Schawweckex (1981).

Het uiteindelijke resultat van de behandeling wordt niet bepala door Een facet van de behandeling maar door het totale pakket van meduche zorg waarmee de patiënt wordt omringt.

5.1. INDICATIES GEHANTEERD BIJ DE KEUZE VAN HET TYPE INTRAMEDULLAIRE OSTEOSYNTHESE

De keuze van de methode van intramedullaire osteosynthese is afhankelijk van de vorm van de fractur en de localisatie van de fractur in de femurschacht (Rehm 1963, Lemens 1970, 1975, Kootstra 1973, Weller 1973, Fer1ife 1975, Müller 1977, Winquist 1980).

5.1.1. Vorm van de fractuur

Bij de indeling nat de vorm van de fractur wordt de klassificatie gevolgd, zoals door Kootstra (1973) is gebruikt. Op grond van de röntgenfoto worden onderscheiden (figuur 8):

1. dwarse fracturen warvan de hoek tussen de fractuuriljn en een lijn loodrecht op de lengte-as van het femur $0^{\circ}$ tot $25^{\circ}$ bedraagt.

2. korte schuine fracturen. Hierbij is de hoek tussen $25^{\circ}$ en $45^{\circ}$.

3. lange schuine of spiraalfracturen. Hierbij is de hoek $>45^{\circ}$.

Bij deze drie fracturtypen kunnen kleine driehoekige fragmenten voorkomen.

4. comminutieve fracturen, warbij een groot deel wan de femurschacht $1 \mathrm{~s}$ betrokken. Zij tonen minimaal viex fragmenten, die in grootte en aantal kunnen variëren.

5. dubbele fracturen, warbij op de röntgenfoto twee fracturen te zilen zijn, die geen relatie met elkar tonen.

Figuur 8. Vorm van de fractuur.
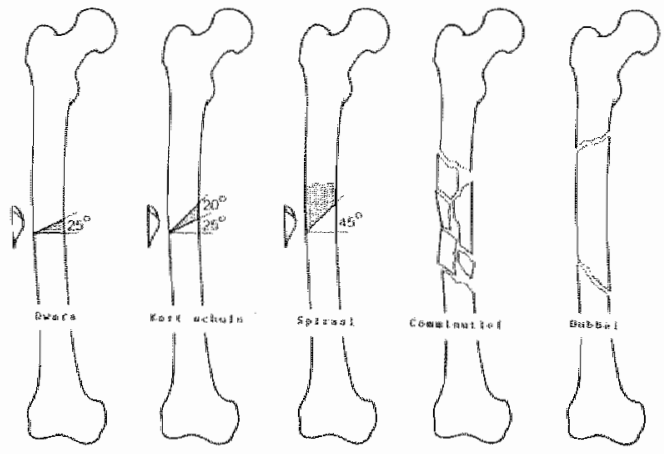

5.1.2. Localisatie van de fractuur in de femurschacht

De mergholte wan het femur heeft een zandlopervorm. Het nauwste deel van het mergkanaal wordt de isthmus genoemd. In een niet voorberelde mergholte van een femur kan een Küntscherpen alleen ter plaatse van deze 1 sthmus inklemmen. Zonder opboren kan met he kintscherprincipe alleen stabllitedt verkregen worden bij fracturen door deze isthmus. 
Doot opboren worden twe voordelen verkregen:

1. de mergholte verandert van een alet geheel ronde vorm in een op doorsmede ronde vorm. Herdoor worden de krachten bij het inklemmen van een. Kintscherpen gelljkmatlg over de cortex van het bot verdeeld. Plekbelabtingen van bepalde delen van het femur door inklemen var de pen worden vermeden (Rehtim 1963).

2. thet het opboren wordt het deel wan de femurschacht war een kintscherpen kan inklemmen vergroot. Het toepassingsgebied voor osteosymese met behulp van een Kintacherpen wordt hlerdoor ult tgebreid.

In deze studle staan van lal patienten röntgenopnamen volgens Spirig ter beschikking warop het niet gefractureerde femur is afgebeeld. De plaats van de 1sthmus van de mergholte is op deze röntgenopname bepaald. De femurschacht $1 \mathrm{~g}$ daarbij in acht segmenten verdeeld. Indien de 1 sthmus op de overgang van twee segmenten is gellegen worden belde segmenten meegeteld. Op dezelfde manier $1 . s$ blj 120 patfënten de localisatie van de fractuur in de femurschacht bepaald. De resultaten van deze metingen zijn weergegewen in tabel 4 (Stapert 1978).

Tabe1 4.

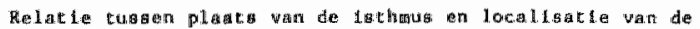

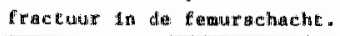

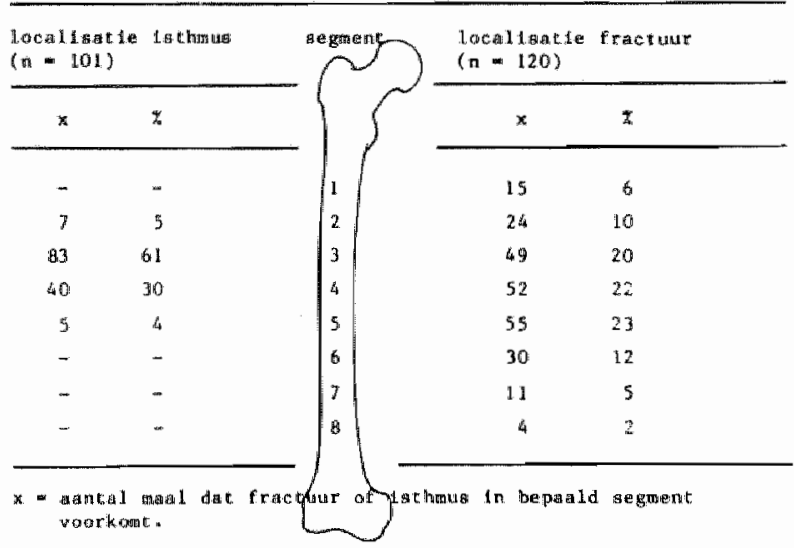

B1 I de onderzochte femora is de 1 sthus in $90 \%$ in segment 3 of 4 gelocallseerd. Slechts $40 \%$ van de fracturen komt voor in deze segmenten. Van deze $40 \% 1$ drlekwart een dwarse of korte schutne fractur. Indien de anwijzingen van ktutscher strikt gevolgd worden, is slechts eenderde van alle femurschachtfracturen geschlkt voor behandeling met een Küntscherpen. Indien bif verder opboren en bif accepteren van relatieve indicaties ook de Küntschertechntek in de segmenten 2 en 5 wordt toegepast, dan kan de helft van alle femurschachtfracturen geschikt worden geacht voor behandeling met een Küntscherpen.

5.1.3. Potentièle 1sthus

Door opboren van de mergholte wordt de isthmus verlengd. Met behulp van röntgenopnamen in twee richtingen kan de lengte van de nieuwe isthmus na opboren worden geschat (figuur 9). De rellatie van de fractuur tot het deel Yan de mergholte waar na opboren met het inwendig verklemingsprincipe stabliltelt kan worden verkregen is de bepalende factor in de indicatie- 
stelling. Lemmens (1970) heeft hiertoe het begrip potentlele isthmus ingewoerd.

Eigur 9. Effect van het opboren.
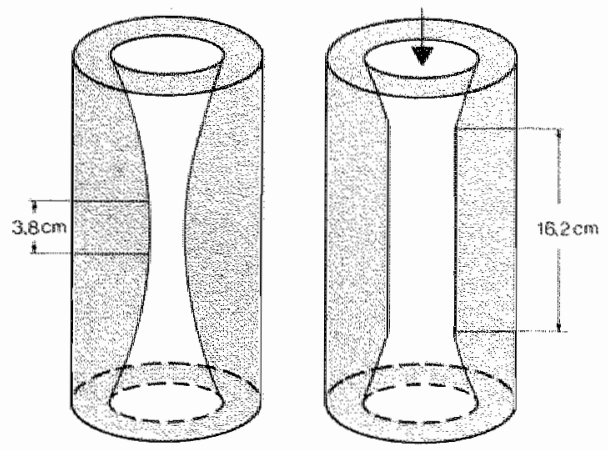

De potentiële isthmus wordt gedefinleerd als dat deel van de mergholte war na opboren voldoende cortical bot overblift on door elastische inkleming van een küntscherpen een stablele osteosynthese te verkrijgen. Dwarse en korte schuine fracturen, al of niet met driehoekig fragment, gelegen binnen de grenzen van de potentiële isthmus zijn geschikt om behandeld te worden met een kintscherpen.

Stabiliteit volgens het Küntscherprinclpe is slechts te verkrijgen; indien de mergpen een schachtbreedte boven en onder de fractuur inklemt. Het door opboren verbrede deel van de mergholte wordt de artificiële isthmus genoemd. De lengte van de potentiële isthmus kont overeen met de lengte van de artificiële isthmus min tweemaal de breedte van de femurschacht:

potentiele isthnus = artificiële 1sthmus $-6 \mathrm{~cm}$.

De lengte van de artificlële isthmus die ontstaat door het opboren van de mergholte is bij 13 a-select gekozen patiënten gemeten op de röntgenopname van het femur (figuur 10). De gemiddelde lengte van de isthmus van de mergholte bedraagt $3,8 \mathrm{~cm}$. De gemiddelde lengte van een segment $1 \mathrm{~s} 4 \mathrm{~cm}$. De gegevens over de lengte van de artiflclële isthmus na opboren van de mergholte zijn weergegeven in tabel 5 .

Tabel 5.

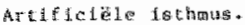

\begin{tabular}{|c|c|c|}
\hline diandere bour & 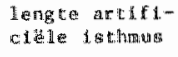 & 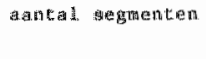 \\
\hline 1.0: & 7,3 cen & 1,8 \\
\hline 12 苗药 & $18,5 \mathrm{ch}$ & 2,18 \\
\hline if 4 | |सासे & $12,11 \mathrm{~cm}$ & 3,0 \\
\hline 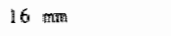 & 15,00 & 3,7 \\
\hline $10 \mathrm{THII}$ & $16,2 \mathrm{era}$ & $c_{i}, 0$ \\
\hline
\end{tabular}

Buiten de potentiële isthmus kan geen stablliteit verkregen worden met de Kuntschermethode. On toch stabiliteit te krifgen moeten bij intramedullaire osteosynthese aanvullende matregelen genomen worden (compressfe en/of cerclage) (Lemens 1975, Schatzker 1980, Winqu1st 1980). 
Q1gurir 10. Artefelele 1sthmus na opboren.

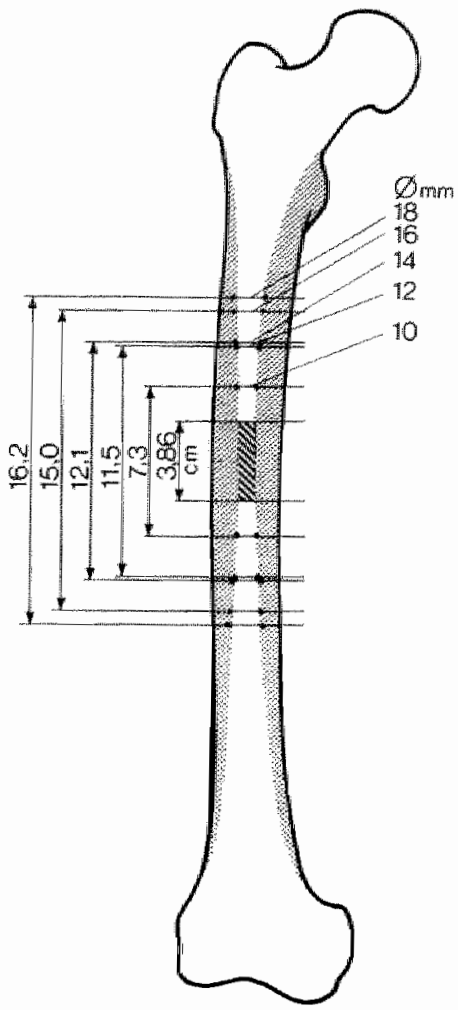

Op grond van deze indeling is de indicatiestelling voor het gebruik van de verschillende osteosynthesen samengevat in tabel 6 en figuur 11.

Tabel 6.

Hind catites intrawedulatire asteosynthese.

\begin{tabular}{|c|c|c|}
\hline \multirow{2}{*}{ vorta vals de fromerum } & \multicolumn{2}{|l|}{$\operatorname{loc} a \log \theta t h$} \\
\hline & 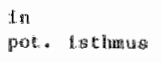 & $\begin{array}{l}\text { buthen } \\
\text { porte. } 1 \text { sthans }\end{array}$ \\
\hline 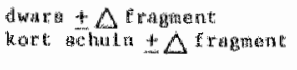 & Rungtsenetren & Kaessuasupen \\
\hline dubber. & 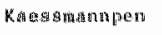 & Kates axman anpen \\
\hline 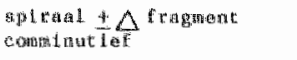 & $\begin{array}{l}\text { Karsamann pern } \\
\text { + colage }\end{array}$ & $\begin{array}{l}\text { Kaessmanatpen } \\
\text { ve cerclagse }\end{array}$ \\
\hline
\end{tabular}

5.2. OPEN VERSUS GESLOTEN REPOSITIE VAN DE FRACTUUR BIJ OSTEOSYNTHESE Indlen de Kaessmannpen wordt toegepast in combinatie met cerclage, is open repositie van de fractur altijd noodzakelijk. Bif de twee andere technieken wordt een open repositie uitsluitend verricht wanneer een gesloten reposttte niet lukt. 

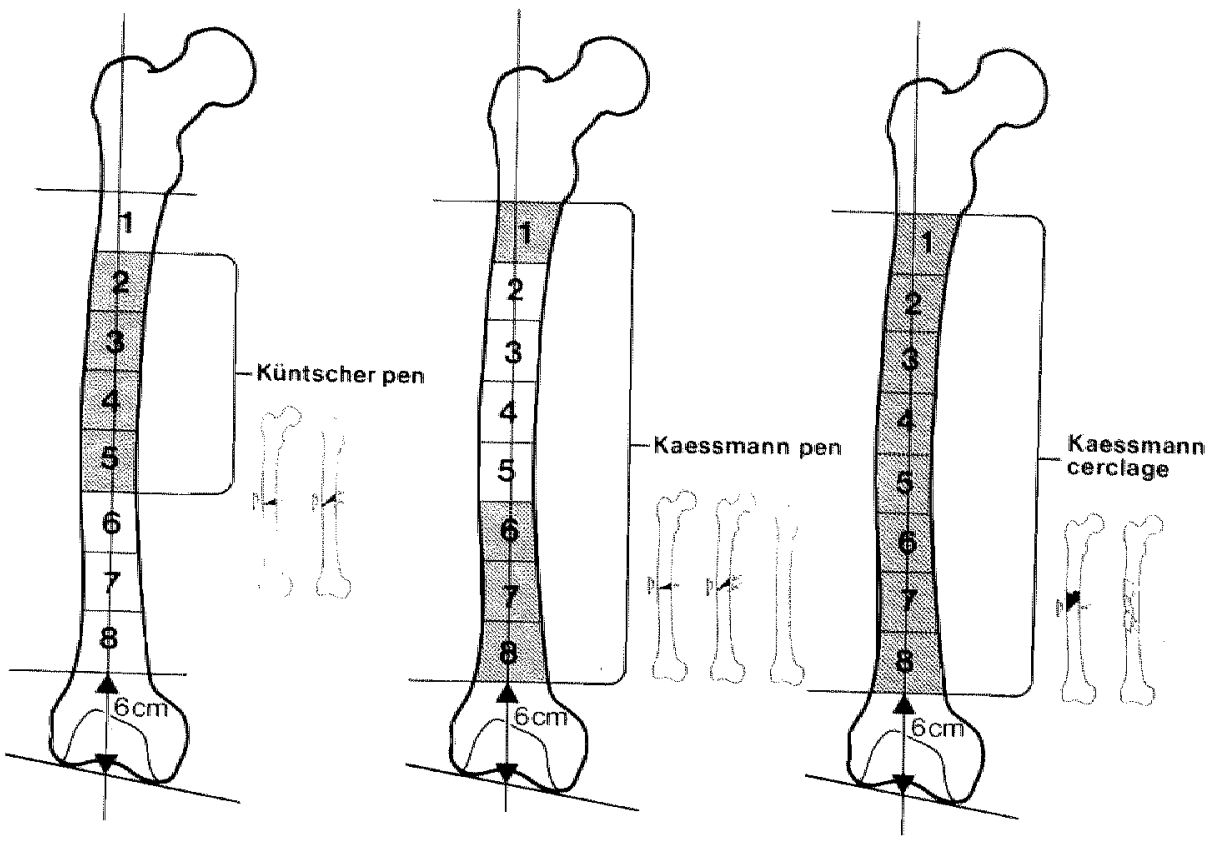

Tabel 7 geeft een overzicht van de verhouding tussen open en gesloten reposities bij de verschillende door ons toegepaste typen van intramedullaire osteosynthese. Bij een studie van 833 intramedullaire osteosynthesen in drie Dultse klinieken, is $1 \mathrm{n} 92 \%$ van de gevalien het ferur gesloten gepend (Weller 1979). Mogelijk speelt de aanwezigheld van boormeel in de fractuurspleet een rol bij de callusvorming, vandaar dat gesloten repositie de voorkeur geniet (Strimer 1983). De A.0.-groep geaft de voorkeur an een open repositie bij intramedulladre osteosymthese (Muller 1977).

Tabel 7.

Ogem/gestotan postite.

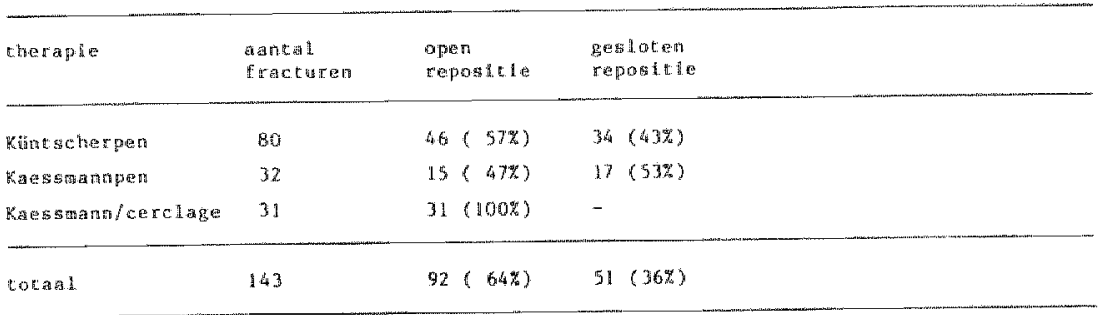


5.3. TLIDSTIP WAN DE OPERATTE

B1j multutramapatienten 1 het noodzakeligk na stabillisatie van circulathe en resplratie en na het behandelen van levensbedrelgende letsels de grote schachteracturen operatief te stabiliseren (Riska 1977, Chapman 1980, Gord: 1982, 1983, A11govex 1983, Tscherne 1983). Ernstige weke delen letsels of huldwonden elders zijn een dwingende reden on acuut te opereret. Gelsoleerde letsels van het fenur worden electief tien dagen na het ongeval geopereerd. Door vele auteurs wordt dit uitgesteld opereren aangeraden, on de verstoorde vascularisatie van het bot gelegenheid te geven te heratellen (Kootstra 1973, Charnley 1974, Weller 1979). Massale revascularisate van het bot vindt een a anvang wanut de weke delen rond de fractuur, tien dagen na het trauma (Rhinelander 1968) (hoofdstuk 4.2.). In onze kliniek wordt on deze reden $1 n$ principe de tiende dag na het ongeval geoperieerd.

\subsection{PRE-OPERATIEVE VOORBEREIDING}

1. Behandelling wan de patiënt direct na opname.

Vanaf het moment, dat een patiënt met een femurfractuur wordt opgenomen, treft men matregelen on an de hand van de registratie van de vitale functies, de conditie van de patient te stabiliseren. De eerste 24 tot 72 uur moet de patiënt zorgvuldig gevolgd worden on een "resplratory distress"-syndroom (vetembolle) ten gevolge van het trauma te voorkomen of in een vroeg stadium te behandelen.

Patienten met een femurfractur hebben $3 n$ in $72 \%$ van de gevallen begeleidende letsels, wardoor in orze kliniek eenderde van de patiënten aanvankelijk op een intensive care afdeling werblijft.

2. Behandeling tot het moment van operatie.

Patienten die electief geopereerd worden krijgen tot het moment van de osteosynthese een draadextensie. Hertoe wordt onder locaal anaesthesie een Kirschnerdraad of Denhamail loodrecht op de lengte-as van de tibia, evenwijdig aan een $11 j n$ door de condylen van het femur, ter hoogte van de tuberositas door de tibla geboord (figuur 12). In de pertode voorafgaande aan de operatle moet, Indien er omstandigheden optreden waardoor osteosynthese niet mogelijk is, de tractle te allen tijde als conservatieve therapie gecontinueerd kunnen worden. Met de draadextensie moet een goede stand van de fractuur worden berelkt. In deze periade moet het bot op lengte gehouden worden, daar door verlles van lengte de kans op slagen van een gesloten repostete verloren gat.

3. Voorkonen van infecte.

De meest gevreesde complicatie van een osteosynthese is infectie. Een aantal pre-operatieve matregelen kan het aantal infecties verminderen:

a. ingpectie van de huld in het operatlegebled en van alle wonden die elders bij het trama zifn ontstaan in de periode v66r de operatie.

b. prepareren van het operatleterrein.

Het scheren van de huld dlent te gebeuren vlak voor de operatie en niet de dag tevoren, angezien kleine huldlaesies dle bij het scheren ontatam, reeds na zes uur geinfecteerd kunnen zijn (Miiler 1977). Bovendlen dient de huid hierna goed mechanisch gereinigd en ontvet te worden (Gezondheldsraad 1977, Manten 1983). De 1\%-jodiuntinctuur moet voldoende gelegenheld hebben in te werken. Het is van groot belang, dat bij het voorberelden en behandelen van de patiënt, vaste protocollen worden gehanteerd. 
Figuw 12. Behandeling tot het moment van operatle.

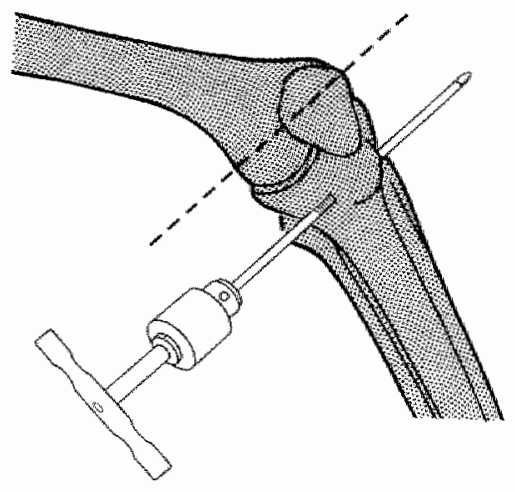

\subsection{LIGGING VAN DE PATIENT}

De osteosynthese kan naar kevze worden uitgevoerd op een röntgendoorlaatbare operatietafel of op een extensietafe1.

Het gebied wan de trochanter major moet goed toegankelijk zijn. De handelingen van het opboren en het inslaan van de pen moeten ongehinderd uitgevoerd kunnen worden. Het in positie brengen van de patiënt is een belangrijk onderdeel van de operatie.

Blj gebruik van een röntgenđoorlaatbare operatietafel wordt de patlënt $t n$ zij11gging gebracht met het gefractureerde been boven, licht gebogen $1 n$ de heup en $90^{\circ}$ flexie in de knie. Het niet aangedane been ligt gestrekt. De patiënt, ook de meervoudig ernstig gekwetste patiënt met meercere fracturen, kan vrljwel altijd in deze houding worden neergellegd.

De extensietafel kan gebruikt worden met de patiënt in rug- of zijligging. Door adductie van het gefractureerde been wordt de toegang tot het mergkanaal verzekerd. Bij de meervoudig ernstig gekwetste patiënt is het gebruik van de extensietafel vak omslachtig en tijdrovend.

Afdekken van het operatieterrein.

Het is niet noodzakelijk een methode dwingend voor te schrijven. Wel th van belang, dat in een bepalde kliniek de afdekprocedure volgeng een bepaald vaststaand schema verloopt. Er moet met en eventuele open reposttide var de fractuur en met de mogelitjkheld tot verkrijgen van gpongleus bot rekening worden gehouden.

Tot dusver is de gang van zaken blj de drle verschillende operatietechnieken gelijk.

\subsection{OPERATIETECHNIEKEN}

5.6.1. Kuntischerpen (figuur 13)

Het is een goede gewoonte, dat de chirurg aan de hand van de röntgenopname van het bovenbeen zo nauwkeurig mogelljk de mat van de te gebruiken pen bepald. Aan de hand hiervan moet gecontroleerd worden of een pen van de gewenste mat aanwezig is.

De operatie wordt begonnen met een lengte-incisie proxinaal van de trochanter major, verlopend in de lengte-as van het femur. De fagela lata wordt gekliefd. Hierna wardt de trochanter gepalpeerd. De merghollte wordt even lateraal en ventraal van het hoogste punt van de trochanter geopend 
met een priem. Dit 1 s een belangrijke stap in de operatie. Een foutlef getozen platis on de mergholte te openen, zal het verdere verloop van de operatle ulerst bemollijken of de operatie onogelijk maken. Vervolgens wordt de boorgelelder, warvan de punt licht gebogen is, door de mergholte tot bij de fractur gebracht. Een poging tot gesloten repositie wordt gedaan. De repositle en het doorvoeren van de boorgelelder in het distale fragment van de fractuur geschiedt onder röntgencontrole in twee richtingen. Het is orverstandig ten koste van alles een gesloten repositie te wllen witvoeren, wegeng de weke delen-beschadiging die optreedt bij langdurige repositlepiogingen. De röntgenbelastlng voor patient en operateur is bovendien aanzlenl1 jk ( 85 m $R$ tot $27 \mathrm{mR}$ ) (M11ier 1983).

Indien een gesloten repositie nlet op korte termijn lukt, is het beter de fractuurdelen vrij te leggen. De benadering van de fractuur geschiedt via een posterolaterale incisie ter hoogte van de fractunr. Wa het klleven van de fascla lata wordt het bot benaderd via de achterrand van de musculus vastus lateralds. Het is van bellang daarbij een geringe afstand van het septum tussen extensoren en flexoren te houden, aangezien het ligeren van de arterien en venen dle dit septum perforeren, hlerdoor vergemakkelijkt wordt. Indien vlak op het septum geprepareerd wordt, kunnen bloedende vaten zlch hierdoor terugtrekken en wordt een goede hemostase bemoeliljkt (Schatzker 1980). Indien men door de musculus wastus lateralis heen naar het femur gat, wordt een deel van de spier gedenerveerd.

Bij de intramedullalre osteosynthese wordt het bot slechts zover vrij! gelegd, dat repositie mogelfjk is. Hoewel anatonische repositie de contrale van rotatlekrachten ten goede komt, is het miet echt essentieel een anatomische repositie uit te voeren.

Na de repositie wordt de boorgeleider onder röntgencontrale opgevoerd in het distale fragment. De punt van de boorgeleider moet centraal liggen in de mergholte, terwijl de punt op het röntgenbeeld gelegen moet zijn op een afstand van ongeveer $3 \mathrm{~cm}$ van het knlegewrlchtsvlak (Schatzker 1980). Vervolgens wordt de mergholte opgeboord met een flexibele boor, die over de boorgelelder heen de mergholte wordt ingebracht. De weke delen worden hierbij beschermd.

Bij osteosynthese wan het femur wordt getracht op te boren tot een diameter van $14 \mathrm{~mm}$. Een pen van deze dikte kan een buigbelasting van $14715 \mathrm{Ncm}$ doorstaan en is stevig genoeg on weerstand te bleden aan de dislocerende krachten waraan deze onderworpen wordt (Küntscher 1967). Zeer belangrijk 19 onder röntgendoorlichting te controleren op welke plaats de boor bij het boren weerstand ondervindt. In princlpe moet men opboren tot die diameter, warbif men weerstand voelt bif boren en op de beeldversterker alet, dat de boor, enkele centumeters boven en onder het niveau van de fractuur, weerstand ontmoet.

Vervoligens wordt de boorgelelder vervangen door de lets dikkere pengeleider zonder knop. Dit geschledt door een plastic buis over de boorgelelder heen in de mergholte te brengen. Hieme wordt de boorgeleider vernfderd. Door deze buls wordt de pengelelder in de mergholte gebracht en de plastic buls verwljderd. De lengte van het utestekende deel van de pengeleider wordt gemeten om de lengte van de pen te bepalen. De chitrurg controleert zelf of dlameter en lengte van de pen kloppen met de vereiste maten. Vervolgens wordt de pen over de pengeledder ingeslagen. De pen moet proximall op gelijk alveau komen met de top van de trochanter major. Distaal moet de pen reiken tot $3 \mathrm{~cm}$ van het kniegewrichtsvlak.

Bly een open repositie moet bij het inslaan, voordat de pen de fracturur passeert, de repositie wat betreft de rotatie gecontroleerd worden. Als orlëntatlepunt bij de beoordeling van rotatie-afwijkingen dient de linea aspera. 


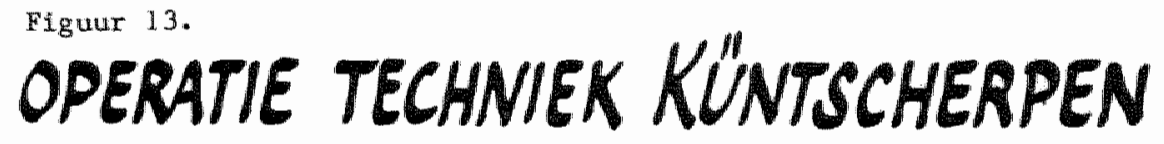

SCHEREN \& DESINFECTEREN

VAN DE HUID.
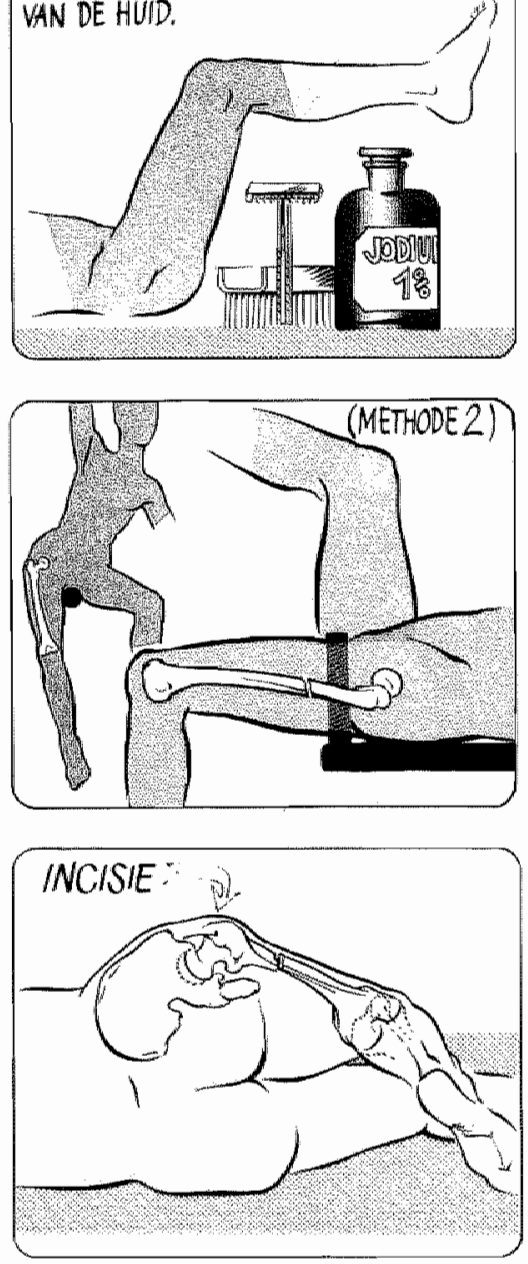
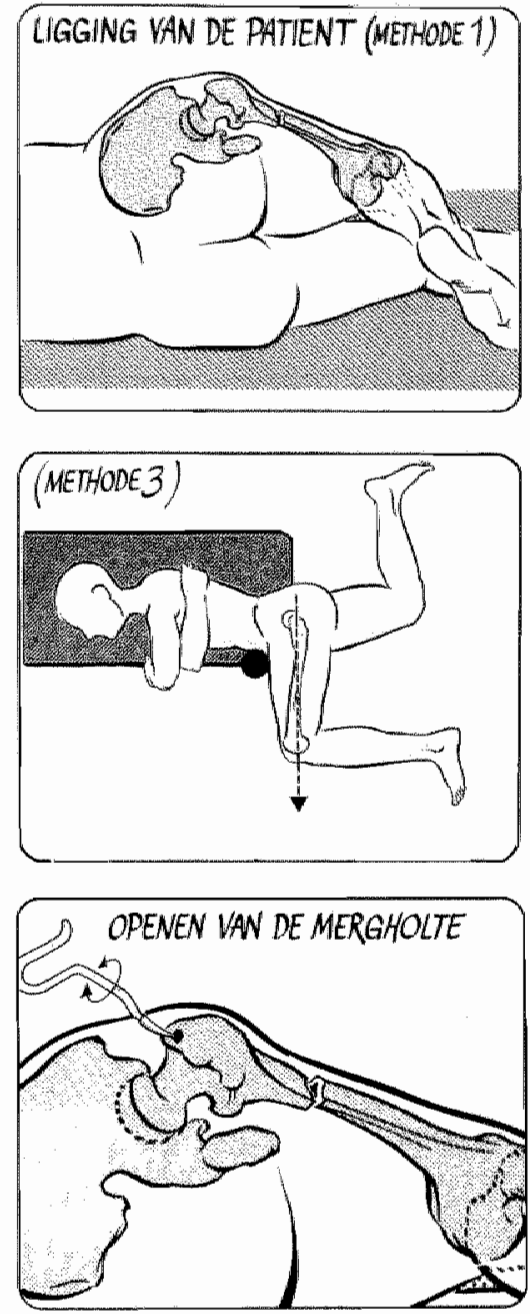

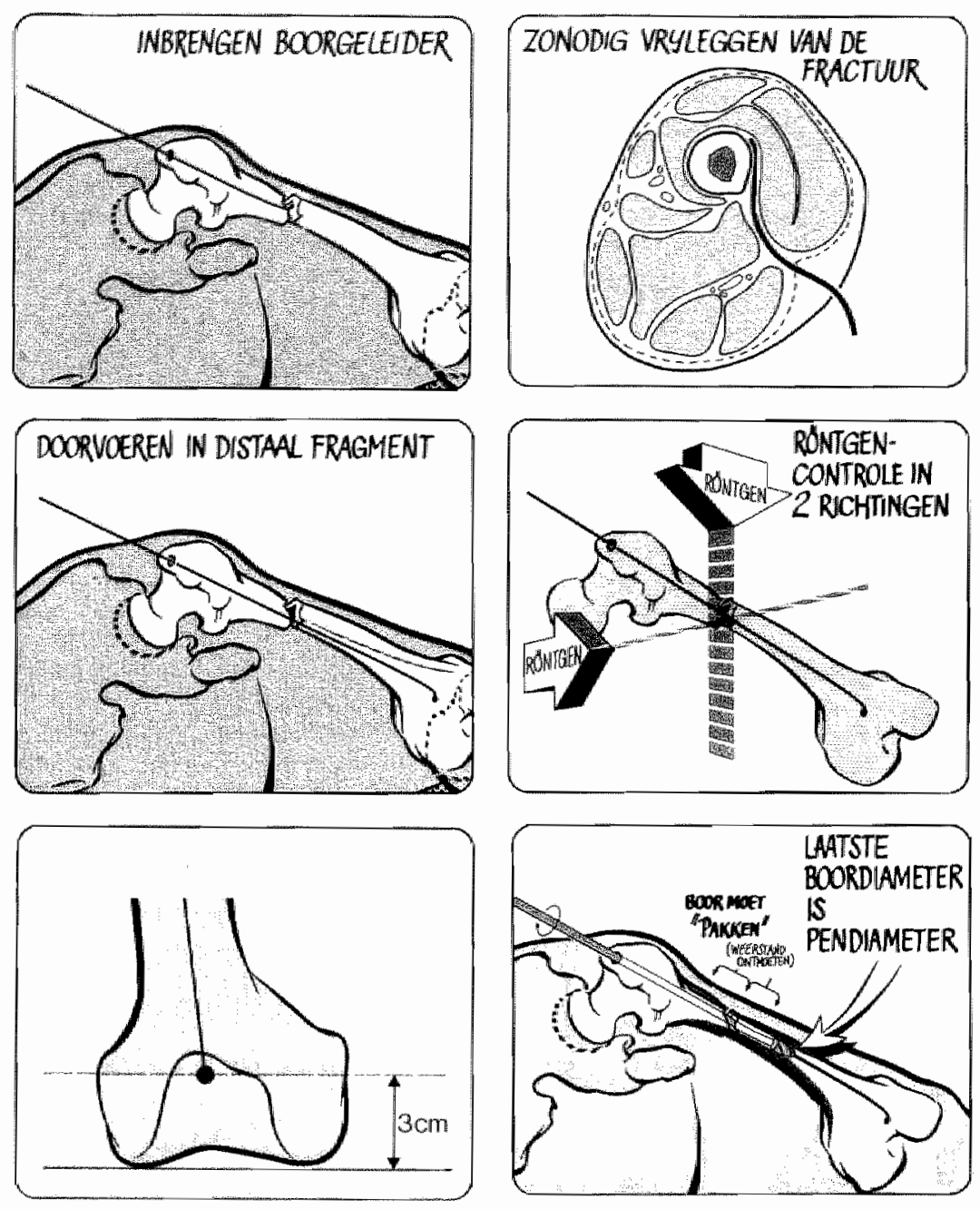

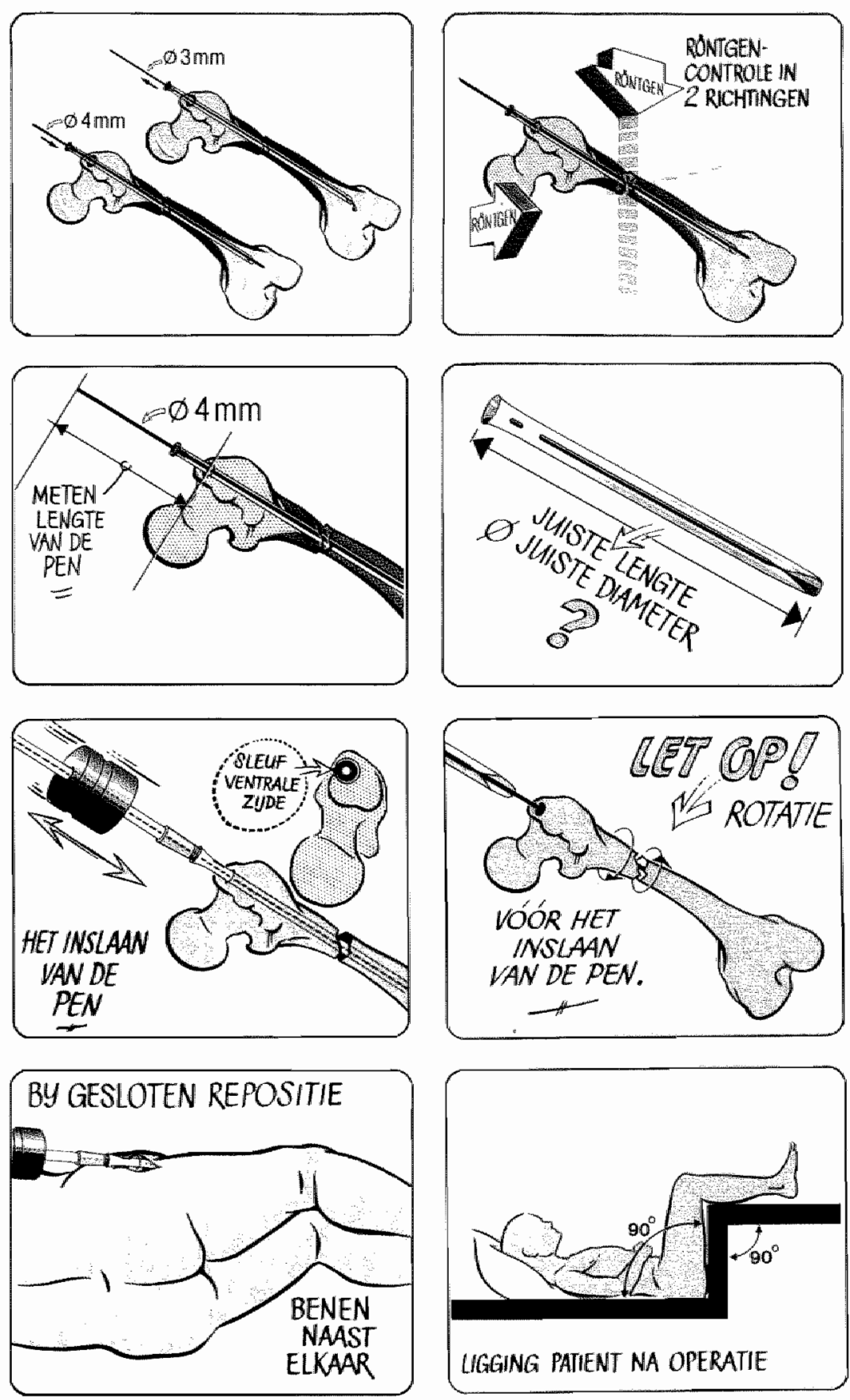
Belangrifk voor een juiste cepositle is, dat blj proximaal en distad gelegen fracturen het labdum mediale niet geplaatist wordt tegenover het lablum laterale van de 1 inea aspera, daar hierdoor aanzlenlijke ratatleafw jkingen optreden. Bij een gesloten repositie dienen beide benen van de patlert inct gebogen knleên thast elkat gebracht worden waardoor grote rotatieafuljkingen wotden woorkomen.

Bif het afdekken moet wet deze manoeuve rekening worden gehouden.

Bif het Inslaan mag geen geveld gebrulkt worden. Er kan beter 0,5 mm meer opgeboord worden, dan het risico te lopen, dat de pen onwrikbaar vast komt te zitten, of dat er door het Insiadn fracturen ontstaan. B1j een open repositle is het wenselljk een visuele controlle uit te voeren naar de mate wan rotatlestabliltelt. Bij minder goede rotatiestabilitelt wordt het nabehandelingsschema aangepast of kan gekozen worden voor het gebrulk van sen grendelpen of het aanbrengen van een klein antirotatieplaatje

(Schatzkex 1980). De wonden worden ower redondrains gesloten. De patient kont met de heup en knle in $90^{\circ}$ flexie te 1 iggen op een Braunse slede.

\subsubsection{Kaessmannpen (F1guur 14 )}

De operatletechniek wijkt wat betreft het openen van de mergholte en $1 \mathrm{~m}$ brengen van de voerdraad ntet af van de methode gevolgd bij de kintschertechniek.

Het opboren kan bij patlëntem boven de 65 jaar valak achterwege blijven. Indien aan de hand van de pre-operatleve foto is vastgesteld, dat de mergtholte wifder is dan $1 \mathbb{L}$ mn, hoeft nlet opgeboord te worden. In geval van twiffel wordt de mergholte énmal gesondeerd met een boor van $11 \mathrm{~mm}$. De spandoorm kan $\mathbb{1 n}$ een wijde merghol te mast de voerdraad worden ingebracht. Na verwljderen van de voerdraad wordt de Kaessmannpen over de spandoorn in de mergholte gebracht. Van belang is, dat de spandoorn in het distale deel van het ferur voldoende beweglngsvrijheld heeft om naderhand in de daartoe bestemde groeve van de Kaessmanmpen gemanoeuvreerd te worden. Ook moet erop gellet worden, dat de spandoorn voldoende onder het distale deel van de Kaessmannpen ut tsteekt om het aambrengen van interfragmentaire druk via tractle an de spandoorn in een later stadium van de operatie mogelijk te maken. Daarom wordt de lengte van de Kaessmannpen zodanig gekozen, dat de spandoorn minstens $6 \mathrm{~cm}$ naar distal uitsteekt. Een anker wordt over de spandoorn geschoven zodat dit rust op het proximale uiteinde van de Kaessmannpen. De 1.p van het proximale deel van de Kaessmannpen moet daarbij zonder interpositte van weke delen rusten op de trochanter major. De beeldversturker wordt nu zodanig ingesteld, dat de stralengang volstrekt loodrecht verloopt op een denkbeeldig vllak, verlopend door het oog van de spandoorn. De beeldversterker stat goed ingesteld indlen het oog in de spandoorn maximal groot is afgebeeld. Een metalen priem wordt evenwijdig aan de stialengang door een kleine incisie zodanig geplaatst, dat deze wordt afgebeeld in het oog van de spandoorn. Onder röntgencontrole wordt de priem door de laterale corticalis, het oog van de spandoorn en de mediale corticalig van het femur gedreven. Door tractie aan de spandoorn wordt gecontraleerd af de ligging van de priem correct is. Vervolgens wordt een zelftappende schroef warvan de lengte gelijk is aan de breedte van het femur door het bot en het $00 \mathrm{~g}$ van de spandoorn gedraaid. De spandoorn is dan middels de dwarsschroef verbonden aan het distale fractuurtragment. Met een speciaal instrument, dat geplaatst wordt boven op het anker, wordt tractie ultgeoefend an de spandoorn. Hilerdoor ontstaat Interfragmentalre compressie in de fractuur. Na het vastzetten van het anker wordt de spandoorn dicht bij het anker afgeknipt en de operatie beëlndigd. De wonden worden over redondrains gesloten. De patiënt komt met knte en heup in $90^{\circ}$ flexie op een Braunse slede te liggen. 
Figuur 14.

\section{OPERATIE TECHNIEK KAESSMANNPEN}

TECHNIEK KAESSMANN. PEN
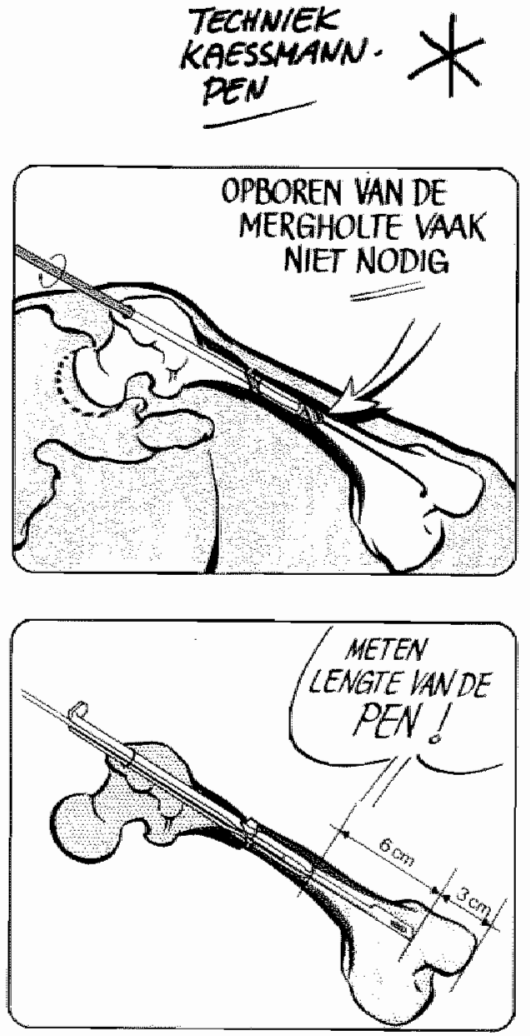
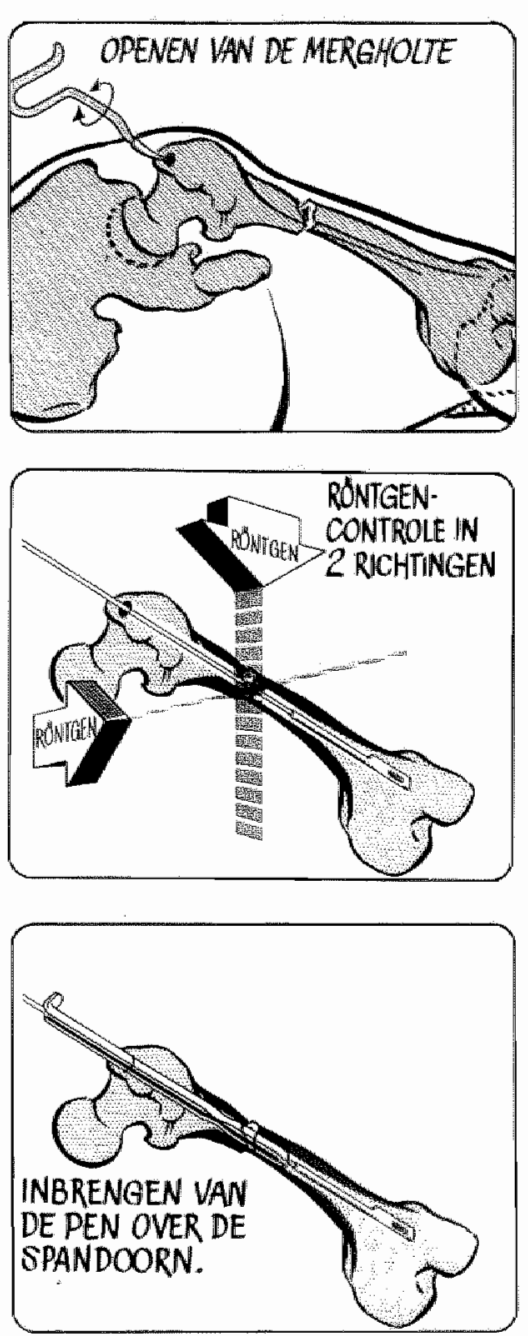

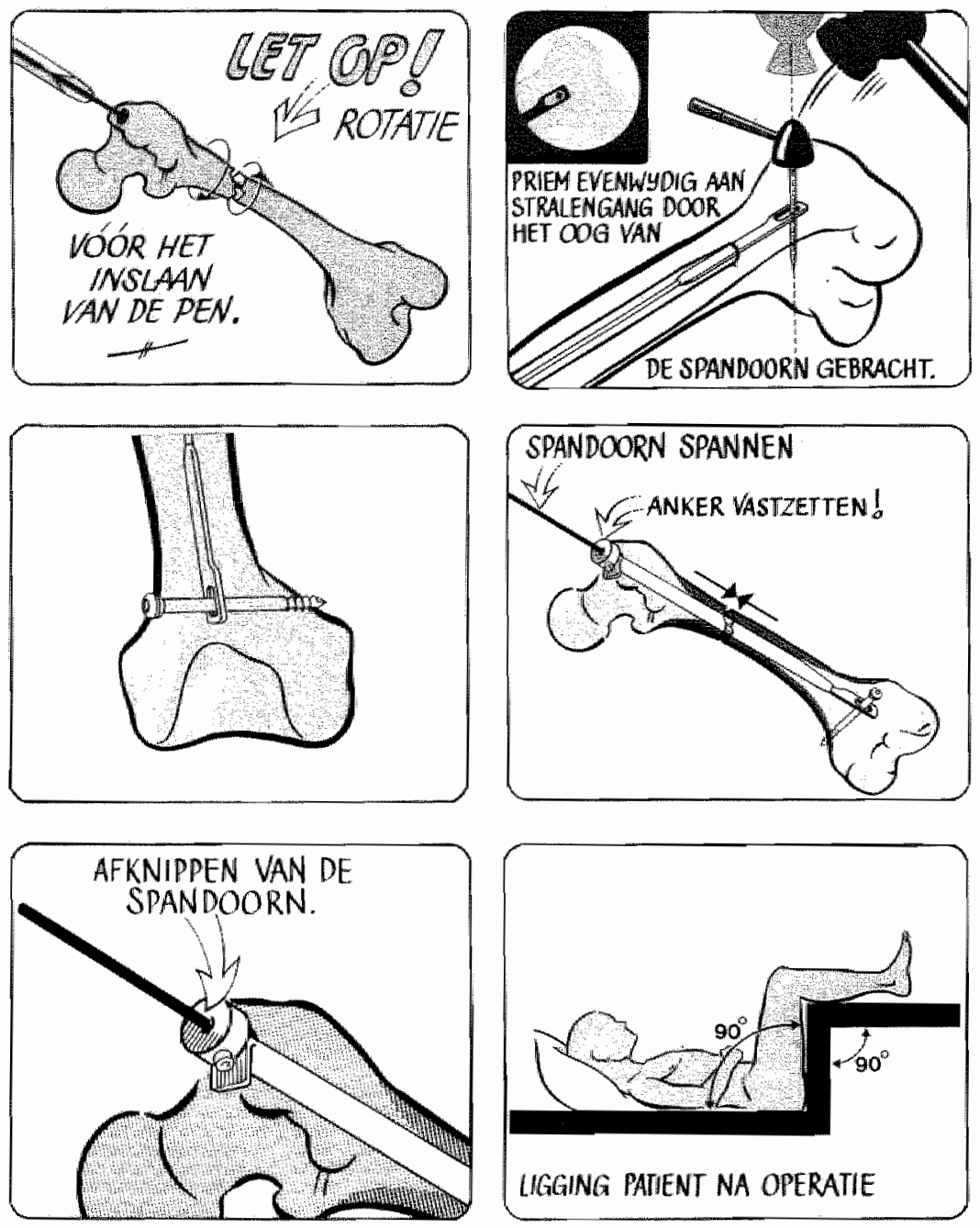
5.6.3. Kaessimanpen in combinatie met cerclage (figuur 15)

De fractuur wordt benaderd via de posterolaterale inclsie Iangs de achterrand van de musculus vastus lateralis. Belangrijk is, dat er niet meer bot vrij gelegd wordt dan absoluut noodzakelijk voor een goede repositie. Wa de repositte wordt de spiralfractur of de fractuur met grote vitale fragmenten gefixeerd met behulp van een antal cerclagedraden met een diameter van 1 man. Er moeten ten minste twee draden worden aangelegd. Bij de repositie moet gewaakt worden, dat kleine fragmenten geen krachten dragen. Het periost wordt niet gestript. De draden worden extra-periostall aangebracht. Hierna wordt de hierboven beschreven procedure met de Kaessmannpen uitgevoerd.

Door het aanbrengen van axiale compressie wijken de fracturfragmenten uiteen. Deze expansie wordt opgevangen door de cerclagedraden wardoor interfragmentaire compressie en stabiliteit ontstaan. Nadat deze stablele vereniging van osteosynthesemateriaal en bot 1 s ontstaan, wordt gecontroleerd welke cerclagedraden vastzitten en welke los. Alleen vastaltende draden zifjn in dit systeem werkzaam. De loszittende draden kunnen verwijderd worden. Tenminste twee draden blifven in situ.

Hiermee is de osteosynthese beëlndigd en wardt de wond over redondrains gesloten en de patiënt op de gebruikelijke wljze verder behandeld.
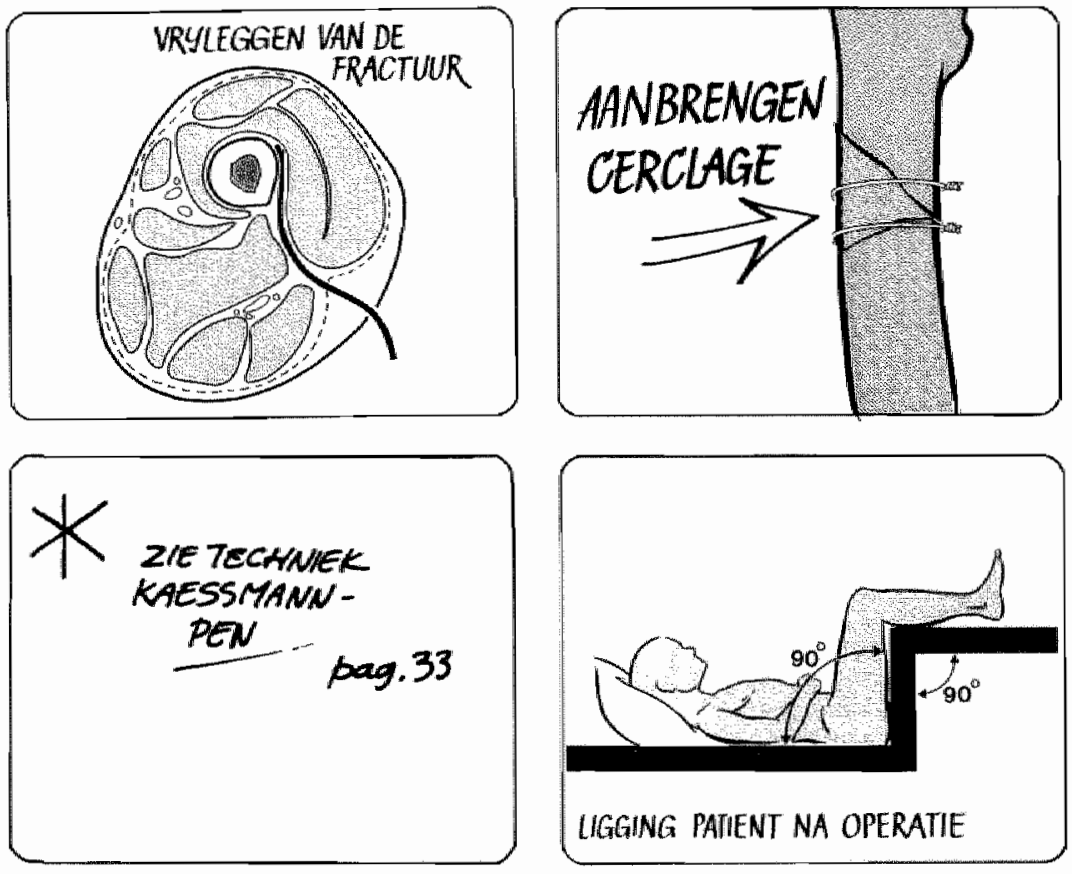

Figuur 15 .

\subsection{NABEHANDELING}

In principe blijft de patiënt in bed tot de operatiewonden zijn genezen. Aangezien de wondgenezing afhankelijk is van de voedingstoestand van de patiënt, wordt zorg gedragen woor een optimale voeding via enteralle of parenterale weg (Schmitz 1983). Redondrains mogen de eerste dag, en moeten op de tweede dag na de operatie worden verwijderd. 
Zodra de postoperatleve pifn dit toelaat, wordt de Braunse slede vervangen door een beweglifke ondersteuning van het been, die actief oefenen van heup-, knie- en enkelgewricht, onder lelding van een fystotherapeut, mogelijk makt. De patient wordt aangezet tot het isometrisch oefenen van de muscultis quadriceps femoris.

Meestal blijkt het mogelifk de patlënten na een week partlëel belast lopend te mobllikeren met elleboogskrukker.

Afhankelijk yan de aard van de osteosynthese wordt de belasting uitgebredd. Dwase fracturen in de patentiële 1 sthmus van het femur behandeld met een Kuntscherpen, kunnen in de regel snel volledig belast worden (Hellex 1979). Blj de met Kaessuanpen en Kaessmann/cerclage behandelde patienten wordt het fenur belagt afhamkelijk van de bevindingen op de rontgenopnamen (hoofdatuk 7.2 .10$. ).

Indien de patiênt 1 s staat is zelfstandig met behulp van elleboogskrukken te lopen, volgt ontslag uit het zlekenhuls (hoofdstuk 7.2.9.).

Cerclagedraden worden in principe zes weken na de osteosynthese verwijderd, daar zif, Indlen langer gewacht wordt, volledig in de callus ingroeten en dan beter in situ gelaten kunnen worden (Winquist 1980).

BLI de pollkllinche contriles wordt veel aandacht besteed aan herstel van het loop- en standpatroon. Door het belasten en normal spiergebruik wordt het ontstaan van atrofle en instablittelt van het been voorkomen. Het osteosynthese materiaal wordt na ongeveer 12 maanden verwijderd. 


\section{Begeleidende letsels}

\subsection{INLEIDING}

Het voorkomen van begeleidende letsels wordt door diverse auteur ntet of vanuit geheel verschlliende gezichtspunten weergegeven. Kootstra (1973) vindt in een serfe wan 329 patiënten bif 149 patienten (45\%) een begeleidend letsel.

Dencker (1963) beschrijft bij 228 (23\%) van 992 door hem bestudeerde patiënten met een femurfractur begeleidende letsels. De aard van het ongeval is van invloed op de aanwezigheid van begeleidende letsels. Zo beschrijft Kootstra (1973) een begeleldend letsel bij $57 \%$ van de patienten net een femurfractuur, ten gevolge van een verkeersongeval.

De aanwezigheid van begeleidende letsels vormt een probleem bij de vergeIijking van de behandelingsresultaten bij verschillende serles patiënten met femurschachtfracturen. Een hulpmiddel om de ernst van de begeleidende letsels uit te drukken is de Injury Severity Score (hoofdstuk 6.3.).

\section{2. INDELING WAN BEGELEIDENDE LETSELS}

Begeleidende letsels kunnen door hun locallsatie het eindresultat van de behandeling beilnvloeden. Begeleldende letsels bij 83 patiënten (67\%) worden door Van Duyn (1977) in een studie van 123 patiënten met supracondylaire femurfracturen, ingedeeld in:

1. algemeen begeleidende letsels die geen directe Invloed uitoefenen op de uitelndelijke functie van het been.

2. begeleidende letsels die door hun localisatie het eindresultat van de behandeling mogelijk belnvloeden:

a. letsels van het homolaterale been,

b. Letsels van het heterolaterale been.

6.2.1. Algemeen begeleidende letsels

De al.gemeen begeleidende letsels oefenen door hun localisatie geen directe invloed uit op het elndresultat wan de behandeling. Grote invloed hebben ze op de algemene conditie, de genezingstendens, morbiditeit en mortaliteit van de patiënt. Bovendien bepalen $z i j$ de volgarde en het tijdstip van het therapeutisch handelen.

6.2.2. Begeleidende letsels die door hun localisatie het eindresultaat van de behandeling mogelijk beinvloeden

Letsels van het homolaterale been worden door Kootstra beschreven $1 n 29 \%$ van de gevallen. Het heterolaterale een toont in $12 \%$ een letsel (Kootatra 1973).

Het moment wan onbelast en volledig belast lopen kan door de aanwelgheld van deze Letsels onathankelijk van de femurschachtfractuur duldelijk bew invloed worden.

\subsection{INJURY SEVERTTY SCORE}

In de jaren zestig is door de Amexikaanse automoblelindustrie veel moelte gedaan een systeem te ontwikkelen om de ernst van geisoleerde stompe letsels blj verkeersslachtoffers in mat en getal ut de drukken. In 1971 wordt door het "Comittee on Medical Aspects of Autonotive Safety" de "Abbreviated Injury Scale" (A.I.S.) ingevoerd. Hiermee is een algemeen aanvaarde methode om de ernst van letsels in mat en getal ut de drukken ter beschikking gekomen. In 1974 gaat susan Baker blj een groep van 2128 patiënten na, in hoeverre de indeling van gewonden met behulp van de A.I.S. correleert met de mortaliteit. Zif legt de nadruk op het vaststellen van de ermst van alle letsels in hun onderlinge samenhang bij multi- 


\section{Injury severity score (I.S.S.) \\ (I.S.S. = som van kwadraten van drie hoogste scores H.T.I.)}

H.T.I.

\section{Pespiratoir}

- gevar Letel.

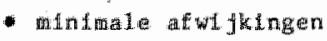

- concelvoudige rib- of gternumeractur ; thoraxcontusie; p1 jn bif ademaliting; longcontusie

- Practur le rib; multipele ribfracturen; haemothorax, pneumothorax

- open thoraxvertonding; enkelz1jdige fladderthorax spantingspheumothorax; enkelvoud1ge dlafragaruptur; trachearuptur

- acute refplotolre cyanose; asplratle; dubbelzijdige fladderthorax; mul to pele d1 af ragnapturen

\section{Cardlovasculair}

- gean letsel

- <500 nl (< 10\%) bloedwerles met normale hufdperfuste

- $500-1000 \mathrm{~m}$. $(10-20 \%)$ bloedverlles met $\downarrow$ huldperfusie

- $1000-1500 \mathrm{ml}(20-30 \%)$ bloedverlles of RR $\leq 100 ;$ myocardcantuste met $\downarrow R R$; hat tamponade

- $1500-2000 \mathrm{~mL}(30-40 \%)$ bloedverlleg met RR $\leq 80$; harteamponade met $\downarrow$ RR

- > 40\% bloedverlies of RR $\leq 60$; comateus, opgewonden/rusteloos t.g.v. haemorthagische shock, hatstilstand of arttmie

C.Z.S.

- geen letsel.

- bchedeltrana zonder bewustzljuswerlides, zonder fractuur

- schedeltratua met kortdurend bewustzifnswerlies (< 15 min.); schede1-

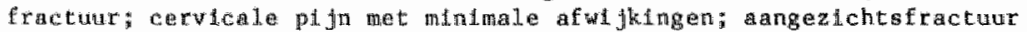

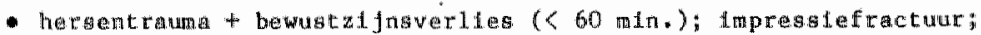
cervicale wervelfractur: met meurologlsche afwikingen; multipele angez lcht racturen

- horsentrauma met langdurig bewstel ynswerlues ( $) 60 \mathrm{~min}$. ) of neurologische alwifklugen; cervicale wewelfractum met b.v. paraplegle

- hersentrama + zaer langdurlg bewhet jnsverlies; gedilateerde lichtatidve pupl1en; cervicale wervelifactur + quadriplegle

\section{Abdomen}

- gerer $\mathbb{1}$ etsed

- pljn buikwnd, rug af tank zonder peritaneale prikkeling

- pifn buikwand, rug of flank met perttonesle prikkeling; fractur van een $11,7-12$; wicroscoplsche hematurle

- mintina leverruptuur, letsel van fejunum/leum, nier, milt, pancreascorpus, urecer, mesenterium, urethra; multipele fracturen ribben $7-12$ 
- Leverrupturr; letsel van blaas, parcreaskop, duodamu of colon, grote mesenter in scheuren.

- gecrushte lever; ruptuur der grote vaten, d.w. van watra, thoracal

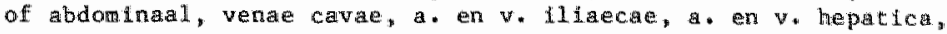
w porta

\section{Extremiteiten}

- geen letsel

- distorsie(s) en minimale fractu(u)r(en) b.v. patellafractur, geen lange pijpbeenderen

- ongecompliceerde fractur: humerus, clavicula, radius, ulna, thbia, flbula, min. zenuwlaesie; enkelvoudig bandletsel vam groot gewricht.

- Tultipele van bovenstaande lesels; gecompliceerdo frectur (geen femufractur); ongecompliceerde femurfrctuna; stablele bekkenfractur; stabiele fractur thoracale of lumbale wervel; grote zenuwheste; luxatie en/of multiple bandletsels groot gewricht

- gecompliceerde femurfractur; crush of amputatie van ên extremiteit; instabiele bekkenfractur; instablele fractur thoras af lumbale wervel

- gecompliceerde bekkenfractur

\section{Huid \& subcutis}

- geen letrel

- <5\% 11chamsoppervlak verbranding; schafwonden of contusle

- 5 - 15\% lichamsoppervlak werbranding; uitgebrelde schaafwonden en/of contuste (> $30 \times 30 \mathrm{~cm})$

- $15-30 \%$ Lichaamsoppervlak verbranding; utgebreide decollenent (> $30 \times 30 \mathrm{~cm}$ ) van de huid

- $30-45 \%$ Lichamsoppervlak verbranding, decollement huld gehele arm of been

- $>45 \%$ Iicham soppervlak verbranding

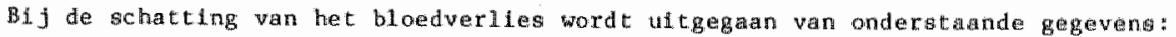

\begin{tabular}{|c|c|c|c|}
\hline Werwacht bloedverlifes: & liters & $\%$ b: & loedvolume \\
\hline gesloten fractuur, per iracturur & $B$ & $\mathbb{A}$ & $\mathrm{B}$ \\
\hline woet, enkel, radlus, ulna & $0,2-0,5$ & 5 & 10 \\
\hline tibia " humerus & $0,5-1,5$ & 10 & 30 \\
\hline temur & $1,0-2,5$ & 20 & -50 \\
\hline hervel & $0,5-1,5$ & 10 & -30 \\
\hline bekkent & $1,0-5,0$ & 20 & -100 \\
\hline$x i b$ & $0,1-0,2$ & 0,2 & $-0,4$ \\
\hline oper fractuur, per fractur extra & $0,5-1,0$ & 10 & 20 \\
\hline
\end{tabular}


tra uria pat 1 enten.

BH Jultitratuapationten stigt de mortaliteit veel sterker dan veraoed kan torden aan de hand van de A.I.S.-gradering. Het blijkt, dat letsels die op zlchzelf geen bedrelging voor het leven van een patient vormen, in combinate met andere letsels, wel lewensgevacrlijk zijn. De oplossing voor dlt probleem wordt gevonden door de A.1.S.-score van de drie meest ernotig getroffen llchambarealen te kwadrateren en dan op te tellen. Zo ontblat de "Injury Severity Score" (I.S.S.). Deze I.S.S. geeft bij multitramapatienten met atompe letsels een goede correlatie met de mortaliteit. De bevindingen van Susan Baker worden door Bull (1975) en Semmlov (1976) bevest1gd. Het is voor de handliggend, dat deze I.S.S. wordt toegepast on traumatologische patienten te karakteriseren. Een verbeterde versle van de A.I.S., de "Hospltal Trauna Index" (H.T".I.) wordt de laatste t1jd wrij algemeen gebrulkt (figuer 16).

Bu $j$ de door ons bestudeerde patienten met een fractuur van de femurschacht wordt aan de hand van de H.T.I. de I.S.S. berekend om de ernst van het geheel van de begeleldende letsels weer te geven (Bul1 1982, Goris 1982 , 1983) (hoofdgtuk 7.2.4.). 


\section{Het na-onderzoek}

7. 1. TNLEIDTNG

Alle na-onderzoek is door de auteur zelf verricht. Alleen door onderzoek door de auteur zell verricht, worden betrouwbare gegevens over patienten met een aandoening van het bewegingsapparaat werkegen (Dencker 1963, Kootstra 1973). Deze onderzoekers hebben eveneens alle patienten zelf gecontroleerd.

Van de niet besproken serie van 139 patiënten, waronder vier patienten met een dubbelzijdige fracturur, zijn ten tijde van het na-ondenzoek nog 127 patienten in leven. Van deze 127 patienten heeft de auteur zelf 119 patiënten ( $94 \%$ ) kunnen na-onderzoeken. Een vrijwel gelijk percentage (95\%) is ook door Kootstra en Dencker berelkt.

7.1.1. Het opsporen wan de patiënten

Aan de hand van de operatieboeken zijn de namen van patieuten die in de periode van 1 januar1 1966 tot 31 december 1976 wegens een femurschachtEractuur operatief behandeld $z \mathbb{i j n}$, verzameld. Uit het medisch archief $z \mathbf{f}$. de zlektegeschiedenissen verkregen. Acht patiënten zijn niet bereikt of blijken niet bereid om aan het onderzoek mee te werken. Van deze acht patiënten blijken vijf patiënten wel bereld om een vragenformulier in te vullen.

Patiënte 005 loopt op 24-jarige leeftijd in segment 6 van de femurschacht rechts een gesloten, dwarse fractuur op. Zij is als voetgangster door een auto aangereden. Ex zljn geen begeleidende letsels (I.S.S. = 9). De zevende dag na het ongeval, is osteosynthese verricht met een küntscherpen. Na $3 \frac{1}{2}$ week is patiente belast lopend uit het ziekenhuls ontslagen. Na twee jaar is de pen verwijderd. Uit het vragenformulier blijkt, dat zij geen enkele klacht van het been theeft en vanaf drie maanden na het ongeval. normaal haar werkzaamheden heeft verricht.

Patiënt 008 loopt op 22-jarige leeftijd ten gevolge van een auto-ongeval een schuine gesloten femurschachtfractuur links op. Het segment van de femurschacht is aan de hand van de beschikbare foto's niet met zekerheld te bepalen. Er zijn geen begeleldende letsels (I.S.S. = 9). Negen dagen na het ongeval wordt osteosynthese met een Kïntscherpen verricht. Na 42 dagen wordt hil, lopend met een elleboogskruk, Lopend uit het zlekeniuis ontslagen. Patënt ls in een zlekenhuls elders gecontroleerd. Na $4 \frac{1}{3}$ maand $\mathbb{i}$ een goede functie van het linker been berelkt. Thans verblifft patiënt $1 \mathrm{n}$ Frankrijk en reageert niet op toegezonden post.

Patiënt 0l8 loopt op 22-jarige leeftijd blj een auto-ongeval in segment 1 , 2,3 en 4 een gesloten, cominutieve proximale femurschachtfractur llinks op. Als begeleldend letsel heeft patiënt een comotlo cerebri (I.S.S. = 20). Tien dagen na het ongeval wordt osteosynthese verricht met een Kaessmannpen en cerclage. Na tien weken wordt patiënt partiè belast lopend ontslagen. Volledige consolidatie treedt op na 24 weken. Na 18 maanden wordt de pen verwijderd. Patient heeft thans principlële bezwaren tegen het na-onderzoek, schrijft geen enkele klacht meer te hebben.

Patlënte 040 wordt op 35-jarige leeftijd als voetgangster door een atto aangereden en loopt hierbij een gesloten dwarse femurschachtfractuur 1 inks op (I.S.S. = 10). Het segment van de femurschacht 1 s nlet met zekerheld te bepalen, ondat niet het gehele femur $t$ i afgebeeld op de röntgenopname. Vijf dagen na het ongeval wordt osteosynthese verricht met een Kaesmanm- 
pen. Wa wif weken is patiente lopend met én stok uit het ziekenhuis ontalagen. De laatete controle heeft 14 weken na het ongeval plaatsgevonden. Er bestat een matige functie, hoewel de fractuur röntgenologische consolidatle toont. Patiente verblifft thang in België en heeft bezwaren tegen de rel nar Magtricht. Volgens het vragenformulier heeft zij matige k.l. achten.

Patient 082 (Engels militair) heeft op 24-jarige leeftijd bij een autoongewal een midschacht femurfractur rechts opgelopen en een aangezichtverwonding $($ L.S.S. $=10)$. Het fotomaterlaal is onvolledig, zodat de fractuur verder nlet gekarakteriseerd kan worden. Er treedt een "respiratory distres" - syndroon op ten gevolge van het trauma. Op de 29ste dag na het ongeval wordt een asteosynthese verricht met een Kintscherpen. Op de zesde dag postoperatlef wordt patiënt overgeplaatst naar een milltair hospitaal en is sindsdien nlet meer bij ons in behandeling geweest. Patiënt verblifft thans in Engeland.

Patiênt $11 \mathrm{l}$ (Engels militalr) loopt op 34-jarlge leeftijd ten gevolge van een automongeval een gesloten, comminutleve femurschachtfractuur links op in segment 3 en 4 (I.S.S. = 36). Patiënt is bij opname in shock. Als begeIeldende letsels heeft patiënt een leverruptuur, letsels van het jejunum, het omentum, en het colon en tevens een bekkenfractuur. Drie weken na het ongewal wordt osteosynthese verrlcht met een Kütscherpen. Zes weken na het ongeval is patient onbelast lopend met elleboogskrukken uit het alekenhuls ontslagen. Patiënt verblijft thans in Engeland.

Pattënt 119 loopt op 18-jarige leeftijd bij een bromfietsongeval een gesloten rechter femurfractuur op (I.S.S. $=10)$. Op de röntgenfoto"s kan het segment en de vorm niet vastgesteld worden. De vijfde dag na het ongeval wordt een osteosynthese met een Küntscherpen verricht. Na $4 \frac{1}{2}$ week wordt patient lopend met éen kruk ontslagen. Na tien maanden wordt het osteosynthese materlaal verwijderd. Pattënt verblifft thans in de U.S.A. Uit het vragenformulfer blijkt, dat hij geen enkele klacht heeft en actief aan sportbeoefening deelneemt.

Patlënt 134 loopt op 19-jarige leeftijd, nadat hij als fletser door een vrachtwagen is aangereden, een gesloten, korte schuine fenurfractuur links op (I.S.S. = 11). Door gebrek aan goede röntgengegevens kan het segment van de fractur nlet worden vastgesteld. Wegens crush en een grote lapwond an de hilel, wordt de dag van opname osteosynthese met een Kuntscherpen verricht. Aan de hiel is necrose van de hudd ontstaan met osteltis van de calcaneus. Verschillende malen is wondtollet en sequesterotomie van de calcameug verricht. Herdoor heeft patiènt $7 \frac{1}{2}$ maand in het zlekenhuls doorgebracht. Patient is niet in de gelegenheld deel te nemen aan het naonderzoek. Uit het vragenformulier vernemen wij, dat hij geen klachten heeft en normaal sport beoefent.

7. 1.2. Procedure bij het na-onderzoek

Bij het na-onderzoek is opnleuw een anamnese afgenomen, lichamel1jk- en röntgenonderzoek verricht. De ongevalstoedracht is vastgelegd, evenals informatie over pre-existente zlekten en het beroep. Het oordeel van de patient over het ultelndelijke resultaat van de behandeling en de bruikbaarheld van het been $1 \mathrm{~s}$ gereglstreerd. De patiënt is gevraagd het resultat van de behandeling te kwalificeren als goed, matig of slecht.

Verder worden alle blijvende pijnklachten of functiebeperkingen geregistreerd, evenals de frequentie van optreden en ernst van eventuele klach- 
ten. De duur van de arbeidsongeschiktheid en het tijustip van sporthervatting zijn vastgelegd. Er is nagegaan of thet letsel van het bovenbeen de studie, sport of beroepsultoefening nadelig heeft beinvloed.

Het fysisch-diagnostisch onderzoek omvat:

- Looppatroon

- stand van het bekken

- Lumbale werwelkolon, vorm en functie

- heupfunctie

- kniefunctie

- enkelfunctie

- kniepeesreflex

- achillespeesreflex

- voetzoolreflex

- sensibilitelt

- pulsaties arteria femoralis superficialis

- pulsaties arteria dorsalis pedis

- pulsaties arteria tibialis poster for

- rotatie-afwijkingen bepald volgens Van Joost (1972)

- afstand spina iliaca anterior superior tot malleolus medialis

- afstand spina iliaca anterior superior tot mediale gewrichtsspleet van het kniegewricht

- omtrek bovenbeen $15 \mathrm{~cm}$ boven het kniegewricht

- omtrek onderbeen $15 \mathrm{~cm}$ onder het kniegewricht

- gewicht van de patiènt

Figuur 17. Metingen op de röntgenfoto.

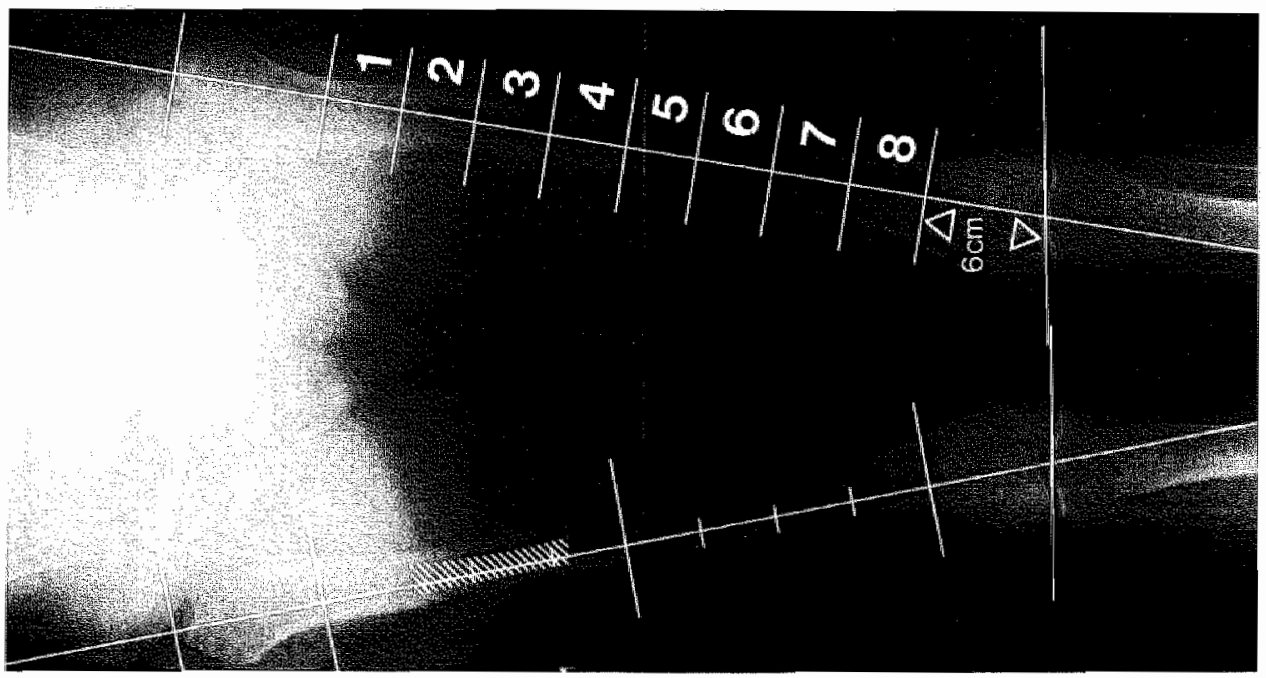

Vervolgens wordt röntgenonderzoek verrlcht. Van belde benen wordt een voorachterwartse opname volgens Splrig (1967) gemaakt, warbif de patiẻnt met het gezicht naar de röntgenbuis staat. Een zijdelings opname wordt alleen gemaakt van het aangedane been, om de stralingsbelasting voor de patient te beperken. De vergrotingsfactor van $1 / 15$ wordt bif de metingen buiten beschouwing gelaten. 
De methgen op de foto ${ }^{\prime}$ zifn verricht volgens het schema weergegeven in figuur 17 .

Begonnen is met het antekenen van de femurschacht zoals weergegeven in hoofdstuk 3.4. Vervolgens is de femurschacht in acht gelijke segmenten viendeeld.

De hoek tussen de as van het femur en de lijn langs de onderbegrenzing van de femurcondylen wordt aan de laterale zljde gemeten. Aan de niet gefractureerde z1 Jde worden dezelfde metingen verricht. Genoteerd wordt in welke segmenten van de femurschacht de fractur is gelocaliseerd. Aan de niet gefractureerde zijde wordt in het fenur de plaats van de isthmus van de mergholte bepaald. Langs de lengte-as wordt de lengte van beide femora gemeten. Een eventuele hoekstand In de zin van varus, valgus, antecurvatie of retrocurvatle wordt vastgelegd. Vervolgens worden alle röntgenfoto's wan de patient opnieuw beoordeeld. Aan de hand van deze serie foto's wordt de beschrijving van de fractuur, de aard van de osteosynthese, eventuele complicaties en tijdstip van de consolidatie vastgesteld. De fracturur wordt als geconsolideerd beschow indien op de rontgenfoto in de fractuurspleet doorbouw, zonder tekenen van sclerose zichtbaar is (Charnley $1974)$.

7.1.3. Overleden patelënten

Van de 139 patiënten met 143 femurschachtfracturen zifn 12 patiěnten overleden. In tabel $8 \mathrm{zljn}$, voor zover bekend, de gegevens van de overleden patlënten weergegeven. Bij de presentatie van de resultaten van het naonderzoek wordt vermeld wanneer de gegevens wan de overleden patiënten worden meegeteld.

Tabe1 8.

\begin{tabular}{|c|c|c|c|c|c|c|c|c|c|c|c|c|c|}
\hline \multicolumn{14}{|c|}{ 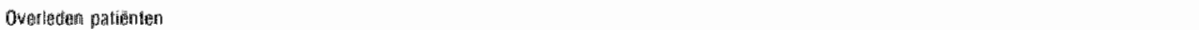 } \\
\hline 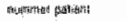 & $\partial 6 \mathrm{il}$ & 903 & bod & 010 & $0,4:$ & $0 \$ 1$ & 053 & 68 & ato & 0958 & 113 & 195 & ใoะ \\
\hline 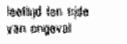 & 50 & $36 \mathrm{~F}$ & 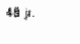 & as. & is is. & 79 & Pll & 证具 & gid it. & $a t$ & $80 \mathrm{H}$ & $\$_{p s}^{s}$ & Is ar logaticideit \\
\hline 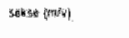 & ifte & s & ש & 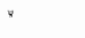 & n & $\alpha_{1}$ & $y$ & $*$ & w & $\pi$ & 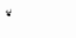 & ли & 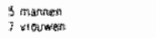 \\
\hline 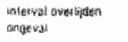 & 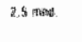 & - & 3 & 2 ז & 24 & a mand. & - & - & ديد & is ment & s netad & 1月 & - \\
\hline 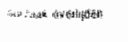 & - & - & 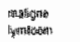 & 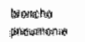 & - & 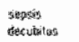 & - & - & - & marsig & 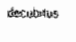 & - & - \\
\hline 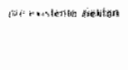 & 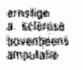 & $\ldots$ & 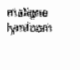 & 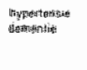 & - & a sorteroted & 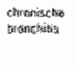 & geati: & gूर:A & aren & 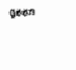 & gesestit & 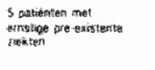 \\
\hline 1045 & 自 & a & $y^{\prime} !$ & $\{\mathrm{k}$ & g & it & g & 和 & 问 & 33 & la & y? & 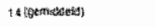 \\
\hline 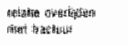 & 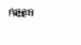 & Figent & तिर्विक्षा & 得 & 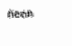 & 随: & กีa & 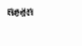 & חaten & 部 & in & ayentan & 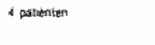 \\
\hline 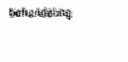 & 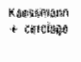 & 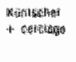 & 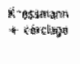 & 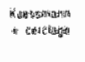 & 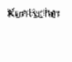 & 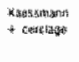 & 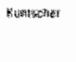 & 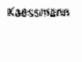 & 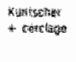 & 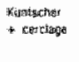 & 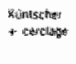 & 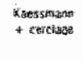 & 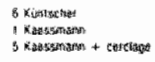 \\
\hline 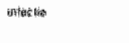 & Sik: & Hpits?: & maism & veretgin & retion & nixis? & 나:현? & rocisitn. & ment: & i & grent & ค月: & 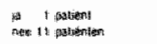 \\
\hline 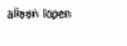 & s & 许 & i & aiten & w & - & 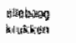 & 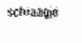 & 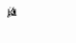 & $x$ & methat & s & - \\
\hline
\end{tabular}

De gemiddelde leeftijd van de groep overleden patienten is 71 jaar. Drie patiënten zljn op jonge leeftijd overleden. De leeftijd van de jongste petięnt $(004)$ bedraagt 48 gaar. Het betreft een man die ten tijde van het ongeval reeds bekend is met een non-Hodgkin Iymphara waraan hij enige tijd later is overleden. De genezling van de fractuur verloopt zonder problemen. 
Patient 001 , een man van 53 jaar, 1 s bekend op de afdeling Algemene Heelkunde wiegens een ernstige atherasclerose, die vóbr het ongeval geỉeid heeft tot amputatie van het rechter onderbeen. Aanslutend an de amputatie is patient psychisch gedecompenseerd Hierna heeft hij door een ongeval in hulls een spiralifractur van de femurschacht aan ile geamputeerde zijde opgelopen. Patiënt wordt behandeld net Kaessmann/cerclage. Na zes weken valt patiënt opnieuw en krijgt een refractuur. Eén dag later verlaat hij het ziekenhuis op eigen verantwoordelijkheid en overiljdt dezelfde dag in een café te Mastricht.

Patient 135 overlijdt op 57-jarige leeftijd door onbekende oorzaak, elf jaar na de femurschachtfractuur *

\section{2. ANALISE VAN HET PATIENTENBESTAND}

Hieronder worden de patiëntengegevens besproken. Uit de ziektegeschiedenissen worden wastgellegd: 1. leeftijd en geslacht, 2. pre-existente ziekten, 3. aard wan het ongeval, 4. begeleidende letsels, 5 . interval tussen ongeval en na-onderzoek, 6. vorm van de fractuur, 7. localisatie wan de fractuur, 8. aard van osteosynthese, 9. opnameduur, 10. verloop van de consolidatie.

7.2.1. Leeftijd en geslacht

De geniddelde leeftijd van de 139 patiënten bedraagt ten tiljde van het ongeval 33,5 jaar. De leeftijdsverdeling van alle patienten wordt weergegeven in tabel 9. De jongste patiënt is een meisje van 14 jaar, de oudste een vrouw van 86 jaar.

Tabel 9.

Leef tijdsverdelirg *

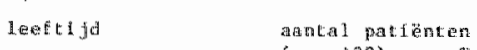

$(\mathrm{n}=139) \%$

$\begin{array}{rrr}0-10 & 0 & 0 \\ 11-30 & 57 & 41 \\ 21-30 & 31 & 22 \\ 31-40 & 11 & 8 \\ 41-50 & 11 & 8 \\ 51-60 & 8 & 6 \\ 61-70 & 7 & 5 \\ 71-80 & 9 & 6 \\ 81-90 & 5 & 4\end{array}$

De leeftijd van $63 \%$ van de patiènten ligt tussen de 14 en 30 jar. De gemiddelde leeftijd van de patiënten behandeld met Küntscherpen, Kaessmannpen en Kaessmann/cerclage is weergegeven in tabal 10 .

De groep van 139 patiënten is samengesteld uit 101 mannen (73\%) en 38 wrouwen $(27 \%)$. De gemiddelde leeftijd wan de mannen bedraagt 31,2 jaar en van de vrouwen 39,6 jaar. Tabel 11 geeft de leeftljd en verdeling van geslacht weer in de verschlllende groepen patlënten. 
Tabel 10.

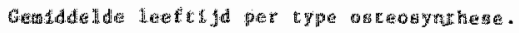

\begin{tabular}{|c|c|c|}
\hline therapie & 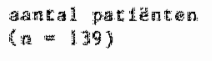 & 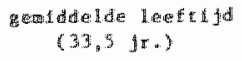 \\
\hline Whind g therpen & 78 & $31,6,15$ \\
\hline Yede & 其政 & 30,4 fr: \\
\hline 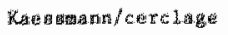 & 30 & $4.1,6.90$ \\
\hline
\end{tabular}

Tabel 11.

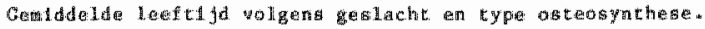

\begin{tabular}{|c|c|c|c|c|}
\hline \multirow[t]{2}{*}{ theraple } & \multicolumn{2}{|c|}{$\begin{array}{l}\text { agntal pattidnten } \\
(n-38)(n-101)\end{array}$} & \multicolumn{2}{|c|}{ gendadelde left lid } \\
\hline & Q & $\sigma^{\prime \prime}$ & $Q$ & o \\
\hline 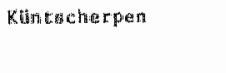 & 26 & 5.4 & $\begin{array}{r}35.75 \\
(15-86)\end{array}$ & $\begin{array}{r}29,651 \\
(14-78)\end{array}$ \\
\hline Kasedstatin pen & 9 & 22 & $\begin{array}{r}43,3 \mathrm{fr} . \\
(15-85)\end{array}$ & $\begin{array}{r}24,8 \mathrm{Jr} \\
(17-46)\end{array}$ \\
\hline 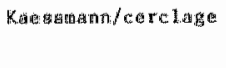 & 5 & 25 & $\begin{array}{c}49,8 \mathrm{Jr} \\
(17-83)\end{array}$ & $\begin{array}{r}40,0, j 5 \\
(17-83)\end{array}$ \\
\hline
\end{tabular}

7.2.2. Pre-existente ziekten

De gemiddelde leeftijd van 31,2 jaar voor mannen en 39,6 jaar voor vrouwen In deze serie patiënten geeft aan, dat de meeste patiënten potentiëel gezond zijn ten tijde van het ongeval.

Bij 11 van de 139 patiënten $(7,9 \%)$, vijf mannen en zes vrouwen, komen pre-existente ziekten voor. Tabel 12 geeft de verdeling van leeftijd, geslacht bij de patiënten met pre-existente afwijkingen.

Tabe1 12.

Premexistente alekter.

\begin{tabular}{|c|c|c|}
\hline & $\begin{array}{l}\text { thancen } \\
(x-5)\end{array}$ & $\begin{array}{l}\text { Wrowkant } \\
(n=6)\end{array}$ \\
\hline 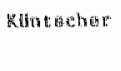 & 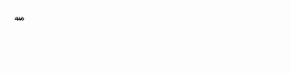 & 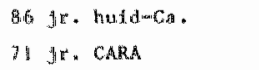 \\
\hline Kosedsenanx & $17 \mathrm{jr} \cdot$ dlabetas & $\begin{array}{l}28 \text { yr. CARA } \\
52 \mathrm{yr} \text {. Enimor cerebrt } \\
75 \text { jr. diabetes }\end{array}$ \\
\hline 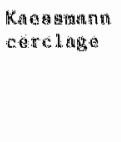 & 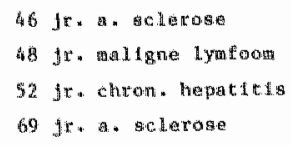 & $\begin{array}{c}\text { yr. hypertendile } \\
\text { damente }\end{array}$ \\
\hline
\end{tabular}

Een man van 45 jaar heeft anamnestisch als kind een homolaterale femurfractuur opgelopen. 
De hoge frequentie vam pre-existente ziekten bij mamen in de groep behandeld met Kaessmann/cerclage berust waarschijnIljk op toeval.

7.2.3. Aard van het ongeval

In tabel 13 wordt een overzicht gegeven wan de ongevalstoedracht. 81\% van de patiënten zijn slachtoffer van een verkeersongeval, Van drie patienten die met een Küntscherpen behandeld zijn en van twee patiënten die met Kaessmann/cerclage $z i j n$ behandeld is de ongevalstoedracht niet bekend, zodat zij niet in tabel $13 \mathrm{zijn}$ opgenomen. Overledener zijn meegeteld.

Tabe 13.

ongevalstoedracht.

\begin{tabular}{|c|c|c|c|c|}
\hline toued racht & $\begin{array}{l}\text { Küntscther } \\
\left(\begin{array}{ll}n & =78\end{array}\right)\end{array}$ & $\begin{array}{l}\text { Kaessmann } \\
(\mathrm{n} \text { is } 31)\end{array}$ & $\begin{array}{l}\text { Kaessmann } \\
\text { cercliage } \\
(n-30)\end{array}$ & $\begin{array}{l}\text { cotas } \\
(\mathrm{n}=139)\end{array}$ \\
\hline
\end{tabular}

\begin{tabular}{|c|c|c|c|c|}
\hline spart & 4 & 1 & 1 & 6 \\
\hline thati.s & 7 & 1 & 5 & 13 \\
\hline Herk & - & 3 & 3 & 16 \\
\hline verkeer - voetganger & 9 & 4. & 1 & 14 \\
\hline - (bran) flees & 39 & 16 & 9 & 64 \\
\hline - auto & 16 & 6 & 9 & 31 \\
\hline onbekend & 3 & - & 2 & 5 \\
\hline
\end{tabular}

$\mathrm{ri}$ a artal patcenten

Opvallend hoog is het aantal patienten met een femurschachtfractuur ten gevolge van een verkeersongeval. Dit aantal van $81 \%$ komt overeen met de $74 \%$ die Kootstra heeft gevonden in een serie van 329 patiënten (Kootstra 1973).

7.2.4. Begeleidende letsels

Van de 139 patiënten met een femurschachtfractuur zifn 19 patiënten ( $14 \%)$ bij opname in shock. Twee patienten $(1,4 \%)$ ontwikkelen aansluitend aan de

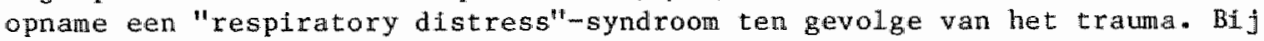
41 patienten $(29 \%)$ is sprake van een neurotrauma.

Bij de beschrijuing van de begeleldende letsels wordt, zoals wergegeven In hoofdstulk 6, gebruik gemaakt van de Hospital Trauma Index (H.T. I.), waruit de Injury Severity Score (I.S.S.) is berekend. De gem $d$ delde I.S. S. van alle patiënten bedragt 14,6. Van alle patiënten heeft $27 \%(\mathrm{n}$ 38) een femurschachtfractuur als enig letsel.

In tabe1 14 wordt een overzicht van de I.S.S. gegeven in relatie tot het optreden van een ongeval bij sport, thuis, werk en verkeer.

Bij de bestudeerde patiënten heeft $81 \%$ de femurschachtfractur opgelopen als gevolg van een verkeersongeval.

De I.S.S. van de slachtoffers van een verkeersongeval is hoger dan dle van de overige patiënten. Een eenvoudige femurfractuur zonder tekenen van shock geeft een I.S.S. van 9. Het is echter zeker niet zo, dat de patienten die thuis of tijdens sportbeofening een femurfractuur oplopen in alle gevallen een I.S.S. van 9 hebben. De invloed van de fractuur op de circulatoire toestand of een begeleidend neurotrama resulteren waak in een hogere I.S.S. 
Wabe 14.

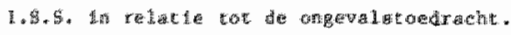

\begin{tabular}{|c|c|c|c|c|c|c|c|c|}
\hline \multirow[t]{2}{*}{ Loed irat hat } & \multicolumn{2}{|c|}{ 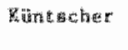 } & \multicolumn{2}{|c|}{ K綵 } & \multirow{2}{*}{\multicolumn{2}{|c|}{$\begin{array}{l}\text { Kaestant } \\
\text { aerelage }\end{array}$}} & \multicolumn{2}{|c|}{ totazi } \\
\hline & 的 & I\$S & 袢 & 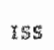 & & & $n$ & ISS \\
\hline aport & $4_{4}$ & 12 & 1 & $\$$ & 1 & 9 & 6 & 11 \\
\hline thuis & 7 & 9 & 1 & 20 & 5 & 25 & 13 & 18 \\
\hline werk & - & - & 3 & 177 & 3 & 15 & 6 & 16 \\
\hline 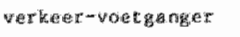 & $y$ & 17 & 4 & 9 & 1 & 9 & 14 & $\mathbb{H} \cdot A_{4}$ \\
\hline - (treotisfiets & 39 & 13 & 16 & 15 & 9 & 13 & 64 & 14 \\
\hline - & 1.6 & 17 & 6 & 20 & 9 & 24 & 31 & 19 \\
\hline
\end{tabular}

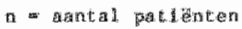

Bij 29 patiẻnten $(37 \%$ ) behandeld met een Küntscherpen komen homolaterale begeleldende letsels voor, die door hun localisatie mogelljk het eindresultat belnvloeden. Deze aantallen bedragen 15 (43\%) voor de Kaessmannpen en 5 (16\%) woor de Kaessmann/cerclage groep.

De frequentte van heterolaterale letsels die het efndresultaat mogelijk belnvloeden $t$ s veel lager. Voor de met Küntscherpen behandelde patiënten bedraagt dit aantal $4(5 \%)$ en voor de Kaessmanngroep $4(13 \%)$. Bij de patfënten behandeld met Kaessmannpen in comblnatie met cerclage komt één $(3 \%)$ ernstig heterolateraal, letsel voor.

7.2.5. Intervall tussen ongeval en na-onderzoek

De patiënten zijn allen behandeld in de periode tussen 1 januar 1966 en 1 Januari 1978. De perlode tussen ongeval en na-onderzoek bedraagt gemiddeld 6,5 jaar $(2-15$ jaar $)$.

7.2.6. Vorm van de fractuur

De indeling naar fractururormen (hoofdstuk 5.1.1.) wordt weergegeven in tabe1 15.

Tabe1 15.

Fractururwormens

\begin{tabular}{|c|c|c|c|c|}
\hline vom & $\begin{array}{l}\text { Notenteder } \\
6 n-73)\end{array}$ & 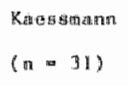 & $\begin{array}{l}\text { Kanemanan } \\
\text { cerclage } \\
(n=31)\end{array}$ & $\begin{array}{l}\text { total } \\
(n=135)\end{array}$ \\
\hline Al whith & 28 & 8 & 3 & 39 \\
\hline 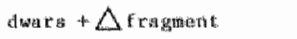 & 14 & 9 & 2 & 25 \\
\hline konte achan 1 in & 15 & 10 & 2 & 27 \\
\hline hort mehal cy to $\triangle$ rraguent & $=$ & - & - & - \\
\hline Bpletal & $y$ & - & 8 & 15 \\
\hline aph that $+\triangle$ terament & - & - & 1 & 1 \\
\hline "ortm l trut ter & 5 & 2 & 15 & 22 \\
\hline aubbat. & 4 & 2 & - & 6 \\
\hline
\end{tabular}

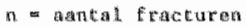


De gegevens van de overleden patiënten zijn meegeteld. De ongevalsfoto's van zeven patiënten behandeld met een Kuntscherpen en én patięnt behandeld met een Kaessmannpen, ontbreken.

7.2.7. Localisatie van de fracturr

De segmenten van het femur betrokken bij de fractuur, zifn weergegeven in tabel 16. Loopt een fractuur door meerdere segmenten dan worden al deze segmenten meegeteld.

Tabel 16.

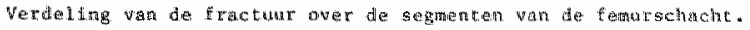

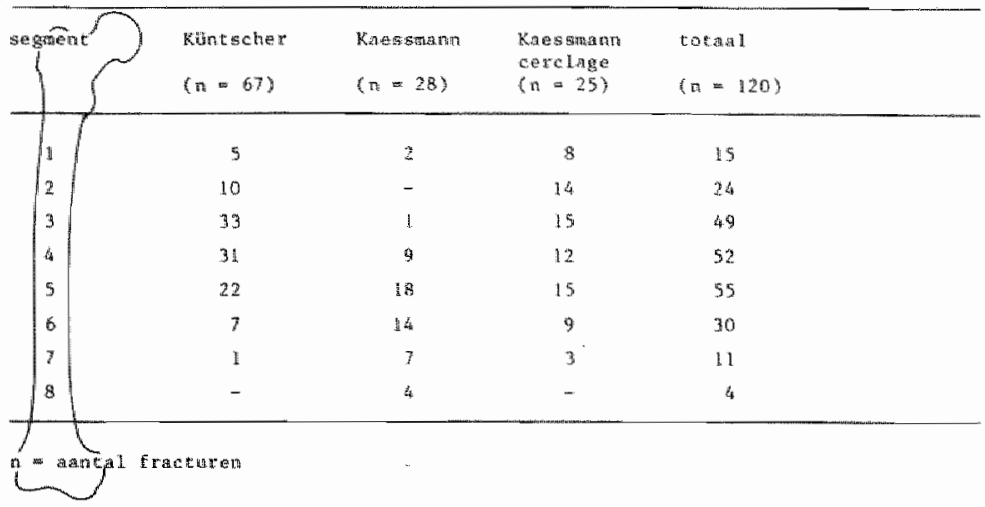

In tabel $16 \mathrm{zijn}$ de overledenen meegeteld.

Bij de met een Küntscherpen behandelde patienten $z 1 j n$ n (78\%) van de fracturen dwars of kort schuln en is $88 \%$ van de fracturen gelegen in de segmenten $2,3,4$ en 5 , owereenkomend met het gebied van de potentiële isthmus.

In de Kaessmanngroep zijn 27 (87\%) van de fracturen dwars en kort schuin en 1 s $52 \%$ van de fracturen gelegen in het gebied van de potentiekle 1 sthmus .

In de Kaessaann/cerclagegroep zijn $24(77 \%)$ van de fracturen spiraalwormig of comminutief en is $74 \%$ van de fracturen gelegen in het gebied van de potentiële isthmus.

7.2.8. Aard van de osteosynthese

Tabel 17.

Toegepaste vormen van asteosynthese.

\begin{tabular}{|c|c|c|}
\hline therapte & $\begin{array}{l}\text { aratal pattidncera } \\
(\mathrm{m}=139)\end{array}$ & $\begin{array}{l}\text { andatal fracturen } \\
(n=143)\end{array}$ \\
\hline Kintsetver & 78 & 80 \\
\hline Raes: smanntr & 31 & 32 \\
\hline Kaestgmantcetolage & 30 & 31 \\
\hline
\end{tabular}

Overeenkomstig de in hoofdstuk 5 beschreven indicaties, 1 g gekozen voor osteosynthese met een Küntscherpen, een Kaessmannpen of Kaessmannpen in 
comblnatle met cerclage. In de groep patienten behandeld met een kütscherpen is $1 \mathrm{n}$ dertien gevallen $(16 \%)$ ook cerclage toegepast, ter verkrijging van voldoende stabl11teit. In tabel 17 wordt een overzicht gegeven van de toegepaste vormen van intramedulladre osteosynthese. De osteosynthese 1 is in de grote neerderheid van de gevallen toegepast als eerste behandellng. Bij drle patiënten is de intramedullaire stabillsatie toegepast na nlet succesvol ingestelde conservatieve therapie. Bij een patiënt ls een Kaesmannpen gebrukt wegens een instabiel gefixeerde dubbele fractuur.

Tabel 18 geeft een owerzlcht van de fracturen waxbij gedurende de operatile de mergholte werd opgeboord. Bij gebrulk wan de Kintscherpen is s.lechts bij én fractuur (zonder cerclage) de mergholte niet opgeboord.

Tabe1 18.

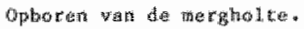

\begin{tabular}{|c|c|c|c|c|}
\hline Eheritate & 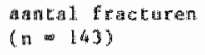 & \multicolumn{2}{|c|}{ 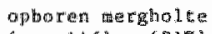 } & \\
\hline Kututechexpoy & 80 & 79 & $(99 \%)$ & \\
\hline 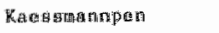 & 32 & 20 & $(63 \%)$ & \\
\hline 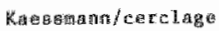 & 1 & 17 & $(55 \mathrm{~N})$ & \\
\hline
\end{tabular}

Bij gebruik van een Kaesmannen is slechts in ongeveer de helft van de gevallen de mergholte opgeboord.

7.2.9. Opnameduur

Een groot deel van de revalidatie heeft in het ziekenhuis plaats gevonden, ondat er ten tijde wan het onderzoek in Maastricht weinig verpleeghuisbedden zijn. De gemiddelde opnameduur wordt hierdoor in ongunstige zin beinvloed. In tabe 19 wordt de geniddelde opnameduur van de eerste opname na het trauma weergegeven.

Tabel 19.

gpmanedun $\mathbf{r}$.

\begin{tabular}{|c|c|c|}
\hline therapta & 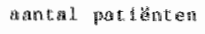 & opyanedrat \\
\hline kthetacherpen & 76 & 57 औ井组略n \\
\hline 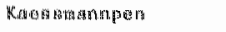 & 31 & 76 d \\
\hline 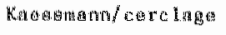 & 28 & 65 d \\
\hline foot efand & 135 & 53 Aagem \\
\hline
\end{tabular}

De gemidelde opnameduur voor patięnten met een femurschachtfractuur bedraagt in de Nederlandse zlekenhuizen in de periode 1970-1972 tussen 62 en 53 dagen athankelijk van de groatte van het ziekenhuis (Informatie S.M.R. 1974). Ten gevolge van het ongeval overleden patiênten zijn in deze geniddelden niet meegenomen.

Zoals gesteld in hoofdstuk 5.3. wordt de osteosynthese meestal tien dagen na het ongeval uitgevoerd. Blj de patiënten waarbij dit uitgesteld opereren volgens plan is ui.tgevoerd, bedraagt de gemiddelde opnameduur vö́r 
operatle 11 dagen $(\mathrm{n}=126)$. Tabel 20 geeft deze getallen weer voor de verschillende asteosynthese typen.

Tabel 20.

opnamedar wort operatie.

\begin{tabular}{|c|c|c|}
\hline thereapie & antal pactäntern & apriatoedunt \\
\hline Runatscherpen & 75 & 11 dagen \\
\hline Kassinanapen & 26 & 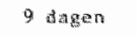 \\
\hline Wetsonan/cerolage & 25 & 10 dagar \\
\hline totas & 126 & 1) dagen \\
\hline
\end{tabular}

In de groep behandeld met een Kïntscherpen zijn drie patiënten niet meegeteld, ondat de operatie is verricht na het mislukken van de primair ingestelde conservatieve therapie (patient 010, 011 en 060). De gentddelde opnameduur vós operatie bij deze drie patiënten bedraagt 66 dagen.

In de Kaessmanngroep zijn vijf patiënten niet meegeteld. Patient 016 is na het wislukken van een osteosynthese met een gebogen Küntscherpen bf l een dubbele fractuur in segment 1 en 8 buiten beschouwing gelaten. De petienten 029, 071, 091 en 137 zijn buiten deze berekening gelaten wegens infectie van ongevalswonden elders op het 11cham, wardoor de osteosynthese is uitgesteld. De geniddelde duur vó6r operatie bij deze vijf patiènten bedraagt 24 dagen.

In de groep behandeld met Kaessmann/cerclage is patiënt 067 wegens een "respiratory distress"-syndroom pas na 25 dagen geopereerd. De patiënten 048, 095, 135 en $141 \mathrm{zijn}$ wegens wondproblemen elders op het 11cham liter geopereerd. De geniddelde tijd voor operatie bij deze vijf patiënten bedraagt 28 dagen.

Bij de berekening van de opnameduur voor verwijderen van osteosynthese materiaal zijn patiënten die tijdens de eerste opname aijn overleden of warbij het osteosynthese materiaal in situ is gebleven wegens hoge leeftijd, niet meegeteld. Ook patiënten die in andere ziekenhuizen nabehandeld zijn of waarbij het verwijderen van osteosynthese materiaal gecomblneerd is met een opname voor een andere afwljking zijn nlet meegeteld. De gemiddelde opnaneduur nodig voor het verwijderen van het osteosynthese materlaal bedraagt 9 dagen, zoals weergegeven in tabel 21.

Tabe1 21.

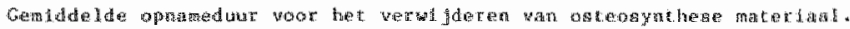

\begin{tabular}{|c|c|c|}
\hline theraptie & nont anterentem & opmameduth \\
\hline 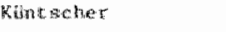 & 51 & A d \\
\hline Kate s sitta: & 16 & 8 diangen \\
\hline 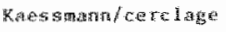 & 18 & 12 diagent \\
\hline 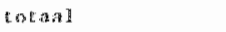 & 85 & 9 dagen \\
\hline
\end{tabular}

De lange opnameduur voor het verwijderen van osteosynthese materlaal wordt verklaard door het indertijd bestaande gebrulk de patiënten zeker tot het verwijderen van de hechtingen opgenomen te houden. Tegenwoordig worden de 
hechtingen in de regel politinisch werwijderd.

De gemiddelde opnanedur yoor de met Kaessnann/cerclage behandelde patiënten bedragt 12 dagen, omdat een extra opnameperiode, zes weken na osteosynthese, noodzakel1jk is wor het verwijderen van de cerclagedraden.

7.2.10. Verloop van de consolidatie

Het tijdstip van onbelast en belast lopen is alleen berekend bij die patienten warbij pre-existente ziekten en begeleidende letsels geen invloed op het tifistip van mobiliseren hebben gehad. Ook patiënten die wegens osteitis of wondinfecte bedrust moeten houden zijn niet meegeteld. Het tijdgtip van de röntgenologische consolidatie is uitsluitend bepald aan de hand van de beschíkbare röntgengegevens.

In tabe1 22 word het gemiddelde interval tussen ongeval, onbelast en walled $1 \mathrm{~g}$ belast lopen in weken weergegeven.

Tabel 22.

verloup van dis consolidatie.

\begin{tabular}{|c|c|c|c|c|c|c|c|c|}
\hline \multirow[t]{2}{*}{ watken tot: } & \multicolumn{2}{|c|}{ Kuirztscher } & \multicolumn{2}{|c|}{ 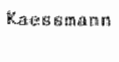 } & \multicolumn{2}{|c|}{$\begin{array}{l}\text { Kadeg smann } \\
\text { ketclage }\end{array}$} & \multicolumn{2}{|c|}{ totatal. } \\
\hline & $n$ & whe & $\mathrm{a}$ & whik & $n$ & wk: & $\Gamma$ & mitic \\
\hline onfoedrat joper & 44 & 2,4 & 19 & 3,3 & 24 & 3,2 & 87 & 2,7 \\
\hline bellabe lopen & 31 & 6,5 & 4 & 14,7 & 7 & 10,3 & 42 & 8,0 \\
\hline$x: 0 .-c o n s o l i d a t i e$ & 62 & 14,9 & 10 & 19,6 & 24 & 13,1 & 93 & 15,0 \\
\hline
\end{tabular}

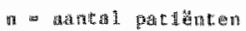

\section{3. RESULTATEN}

Het behandelingsresultat van de verschillende osteosynthese typen bif patiënten met een femurschachtfractuur wordt beoordeeld aan de hand van anatonische en functionele parameters.

\subsubsection{Anatomische resultaten}

Een goede repositie van een fractuur wordt gekenmerkt door herstel van lengte zonder hoekstand en rotatie. De resultaten van het anatomische herstel wan een letsel van het bovembeen $z$ djn daarom ondergebracht in drie categorleën: 1. afwljkingen ln lengte; 2. hoekstanden; 3. rotatiemafwijkingen.

\subsubsection{Aftwiktingen in botlengte}

Van de meeste patienten is nast de klinisch gemeten beenlengte ook een röntgenopname volgens Spirig (1967) beschikbaar. De meting van de botlengte is op de röntgenfoto verricht. Algemeen wordt aangenomen, dat lengteverschilien tot $2 \mathrm{~cm}$ zelden aanlelding geven tot klachten (Winant 1949, kootstra 1973). De patiënten waarvan de lengte op de röntgenfoto op betrouwbre wjze kan worden gemeten, zijn weergegeven in tabel 23 , werdeeld nar aard van osteosynthese.

De fracturen van 12 overleden patiënten, vier patiënten met dubbelzijdige fracturen, één patiënt met een amputatie, acht patiënten dle niet zijn na-onderzocht, en van zeven patiënten met een voor betrouwbare meting niet bruikbare foto, zijn buiten beschowing gelaten.

Het grootste lengteverlies van $3,5 \mathrm{~cm}$ is gemeten bij twee patiènten behandeld met Kaessmann/cerclage. De grootste gemeten lengte-toename bedraagt $1,7 \mathrm{~cm}$ bij een $32-$ Jarige patiënt behandeld met een küntscherpen. Uit de 
gegevens blifkt dat verlies wan lengte bij intramedulaire osteosynthese geen groot probleem vormt. Slechts drie $\left(2,1, b^{\prime}\right)$ patientun hebben tiear dan 2 cin botlengteverlies.

Tabel 23.

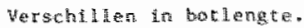

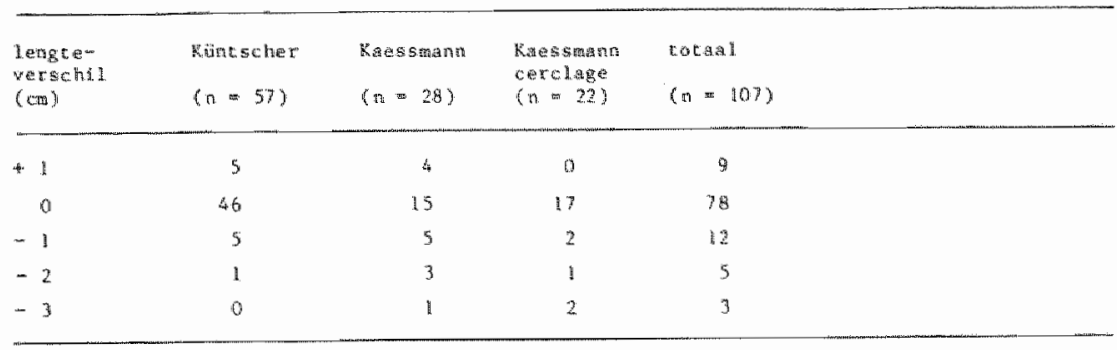

n a a a a t al fracturen

\subsubsection{Hoekstanden}

De afwljkingen in de asrichting van het femur $z 1 j n$ aan de hand van AP en zijdelingse foto's gemeten. Een varusstand geeft meer klachten dan een valgusstand. De frequentie van klachten neemt toe, naar mate de 1 n een hoekstand genezen fractuur meer distal gelegen is. Meestal ziln dit knie= klachten (Debrunner 1967, Kootstra 1973).

Aan de hand van AP en zijdelingse röntgenopnamen is de asrichting bepald bij 114 patiënten. Niet meegeteld zljn de fracturen van 12 overleden patiënten, patiënten die niet aan het na-onderzoek hebben deelgenomen, Een amputatiepatiënt en vier patiënten met onvolledig fotomatertaall. In tabel 24 worden de metingen van de hoekafwijkingen in het frontale wlak, verdeeld naar de ard van de osteosynthese weergegeven *

Tabe1 24.

thoekstanden in het froukan viak.

\begin{tabular}{|c|c|c|c|c|}
\hline hoek:s tand & $\begin{array}{l}\text { Nint scher } \\
(m-6.5)\end{array}$ & $\begin{array}{l}\text { Kat es shand } \\
(n-29)\end{array}$ & $\begin{array}{l}\text { Kaessuann } \\
\text { cerclage } \\
\text { (n cos } 24)\end{array}$ & $\begin{array}{l}\text { cotalal } \\
(n=1 / B)\end{array}$ \\
\hline Yarus/valgus $<5^{0}$ & 58 & 20 & 24 & 102 \\
\hline warustualgus $25^{\circ}$ & 7 & 9 & 0 & 16 \\
\hline
\end{tabular}

5)

Van de 118 fracturen met betrouwbare röntgengegevens aijn 102 (86\%) fracturen genezen zonder noemenswardige valgus- of varusstand. De hoekatwlkingen bij de overige patiënten zijn weergegeven in tabel 25.

slechts één patiënt heeft een valgusstand van meer dan $20^{\circ}$. Het 1 s een man van 24 jaar, patiënt 042 (I.S.S. $=10$ ). De dwarse gesloten fractuur in segment 5 en 6 van de femurschacht rechts, ontstaan na een bromfietsongeval, is behandeld met een gesloten repositie en fixatie met een Kassmannpen. Infectie en sequesterotomieên hebben geleld tot een valgusstand van $22^{\circ}$ met $2 \mathrm{~cm}$ verkorting. Er $z i j n$ geen afwijkingen in het saglttale vlak of rotatie. 
Tabel 25.

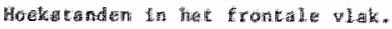

\begin{tabular}{|c|c|c|c|c|}
\hline hock to tand & $\begin{array}{l}\text { Returechet } \\
(n=7)\end{array}$ & 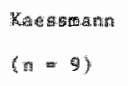 & 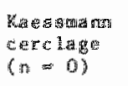 & $\begin{array}{l}\operatorname{tac} a d x \\
(n+15)\end{array}$ \\
\hline \multicolumn{5}{|l|}{ 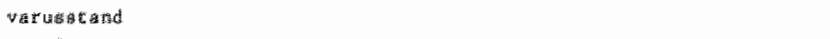 } \\
\hline$y^{\circ}$ & - & 2 & - & 2 \\
\hline $10^{00}$ & $\cdots$ & 1 & - & 1 \\
\hline 190 & - & - & $\ldots$ & - \\
\hline \multicolumn{5}{|c|}{ Wa Leugntand } \\
\hline $5^{0}$ & 5 & 3 & - & 10 \\
\hline $10^{\circ}$ & 2 & - & - & 2 \\
\hline $15^{\circ}$ & - & I & - & 1 \\
\hline
\end{tabular}

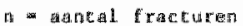

Ante- en recurvatie.

In tabel 26 worden de patiënten met hoekafwijkingen in het sagittale viak, verdeeld naar aard van de osteosynthese weergegeven.

Tabel. 26.

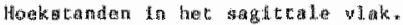

\begin{tabular}{|c|c|c|c|c|}
\hline hoeketiand & $\begin{array}{l}\text { Kuntecher } \\
(n=62)\end{array}$ & $\begin{array}{l}\text { Raes smangu } \\
(n * 29)\end{array}$ & $\begin{array}{l}\text { 酷essann } \\
\text { cerclage } \\
(n=24)\end{array}$ & $\begin{array}{l}\text { totana } \\
(n-115)\end{array}$ \\
\hline antefrecorvatie $<5^{\circ}$ & 59 & 23 & 21 & 103 \\
\hline ante/recurvatie $\geq 5^{\circ}$ & $y$ & $f_{0}$ & $y$ & 12 \\
\hline
\end{tabular}

$n=$ andition fracturen

De fracturen van overleden patlënten, de amputatlepatiënt en zeven patiënten met onbrulkbaar fotomateriaal zijn niet bif het opstellen van deze tabel betrokken.

In tabel. 27 wordt de ante- en recurvatie van de patiënten verdeeld natar osteosynthese, weergegeven.

Van de 115 onderzochte fracturem $z 1 j n 103$ (90\%) zonder noemenswaardige ante- of recurvatie genezen. Wff fracturen $(4,3 \%)$ tonen een antecurvatie, zeven fracturen $(6,1 \%)$ een recurvatie. Bij patiente 106 behandeld met een Kaessmannen bedraagt deze $23^{\circ}$. Het 1 s een 82 -jarige multitraumapat dënte (I.S.S. 20) met een dwarse gesloten fractuur in segment 8 , die na open repositle in deze stand gefixeerd is met een Kaessmannen. Patiènte loopt met behulp wan een schraagje, ondanks een tibiaplateaufractur aan de homolaterale zifde.

\subsubsection{Rotatie-afwijkingen}

Rotatie-atwijkingen zljn beoordeeld aan de hand van klinisch onderzoek met de methode van Van Joost (1972). Van röntgenmeting waarbij toename of afname van de anteversle wordt vergeleken met de gezonde kant, is wegens de stralenbelasting afgezlen (Rippstein 1955). Tabel 28 laat de verdeling van patiënten met rotatle-afwijkingen zien. Rotatie-afwijkingen kleiner dan $10^{\circ}$ zijn als niet afwijkend beschouwd. 
Tabe1 27.

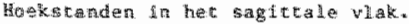

\begin{tabular}{|c|c|c|c|c|}
\hline 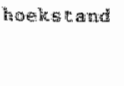 & $\begin{array}{l}\text { Kuntecher } \\
(\mathrm{n}=3)\end{array}$ & $\begin{array}{l}\text { Katsiann } \\
\operatorname{tn}=6)\end{array}$ & $\begin{array}{l}\text { Kassman } \\
\text { nenclas } \\
(\mathrm{a}=3)\end{array}$ & 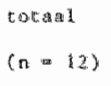 \\
\hline \multicolumn{5}{|c|}{ encearnatio } \\
\hline $5^{\circ}$ & 1 & 3 & - & $A$ \\
\hline $10^{02}$ & - & 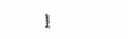 & - & 1 \\
\hline $1.5^{\circ}$ & - & - & - & - \\
\hline $20^{\circ}$ & - & $\cdots$ & arr & - \\
\hline \multicolumn{5}{|l|}{ recurvatie } \\
\hline $5^{\circ}$ & 2 & 1 & 2 & 5 \\
\hline $10^{\circ}$ & - & - & 1 & j \\
\hline $15^{\circ}$ & - & - & - & - \\
\hline $20^{\circ}$ & - & 1 & - & 1. \\
\hline
\end{tabular}

a anatal fracturen

Tabe1 28.

Rotat le-afwi jleingen.

\begin{tabular}{|c|c|c|c|c|}
\hline rotatie & $\begin{array}{l}\text { Kunt sicher } \\
(1+62)\end{array}$ & $\begin{array}{l}\text { Katsesinamo } \\
(n=26)\end{array}$ & $\begin{array}{l}\text { Kaes sman } \\
\text { cerciage } \\
(n=(9)\end{array}$ & $\begin{array}{l}\text { totanl } \\
(n=107)\end{array}$ \\
\hline $10^{\circ}<$ & 33 & 14 & 10 & 57 \\
\hline $10^{\circ} z$ & 29 & 12 & 9 & 50 \\
\hline
\end{tabular}

nowatial fractren

In deze tabel zijn niet meegerekend de gegevens van de 12 overleden patiënten, van vier patiënten met dubbelzijdige fracturen, van acht patiënten die niet hebben deelgenomen aan het onderzoek, van vijf patiënten bij wie wegens arthrose de rotatie-afwijtng niet meetbaar is, van Een patient met pre-existente rotatie-afwijklngen, van Eén patiènt bij wie het been $1 \mathrm{~s}$ geamputeerd en van éfn patiënt bij wie bij fysische diagnostiek vergeten is all de rotatiestand te beoordelen.

In de groep van 107 fracturen komt in 50 gevallen (47\%) rotatle-alwifkingen van meer dan $10^{\circ}$ voor. In tabel 29 wordt de ernst en verdeling van deze rotatie-afwijkingen over de verschillende groepen weergegeven.

De frequentle van de gevonden rotatie-afwijingen komt overeen met de gegevens die Kootstra (1973) darover heeft verzameld.

Vier fracturen in de Küntschergroep tonen ernstige exorotatle-afwijkingen

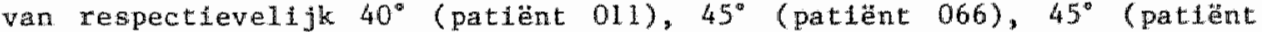
086) en $40^{\circ}$ (patiènt 087). In de Kaessmann/cerclagegroep heeft én patlënt $40^{\circ}$ exorotatie (patiënt 139 ).

Patiënt 011 (I.S.S. = 13) 1s een 14-jarige scholler met als enfg letsel. een gesloten, dwarse femurfractuur Ilnks in segnent 2 , die behandeld 1 i met een $1 \mathrm{~d}$ m Künscherpen. Er is geen hoekstand. Ex wordt een exorotatie 
van $40^{\circ}$ geconstateerd. B1 het na-onderzoek blijkt deze patiënt knieklachten te hebben. Op de röntgenfoto van de knle is na acht jaar geen arthrose gezlen. Deze patient is eén deroterende osteotomle angeraden.

Tabe1 29.

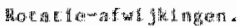

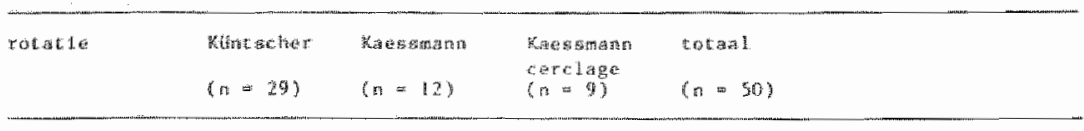

\begin{tabular}{|c|c|c|c|}
\hline $10^{0}$ & 6 & 3 & - \\
\hline $201^{03}$ & سم & if & 1 \\
\hline $30^{25}$ & $m$ & w & - \\
\hline $0^{\circ}$ & - & - & 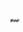 \\
\hline
\end{tabular}

\begin{tabular}{|c|c|c|c|c|}
\hline $10^{\circ}$ & 7 & 3 & 1 & 11 \\
\hline $20^{\circ}$ & 6 & 2 & 3 & $\| \mathrm{y}$ \\
\hline $30^{0}$ & 6 & 3 & 3 & 12 \\
\hline $40^{\circ}$ & $d$ & - & 1 & 15 \\
\hline
\end{tabular}

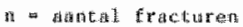

Patfent 066 (I.S.S. $=14$ ) is ten tijde van het ongeval 17 jaar. Een geisoleerde, dwarse femurschachtfractuur rechts in segment 3 is behandeld met een Kintscherpen na opboren van de mergholte (13 mm doorsnede). Zij loopt goed met de voet in exorotatie. Bij klinisch onderzoek wordt $45^{\circ}$ exorotatie gevonden. Ook haar is een deroterende osteotomie aangeraden.

Patlënt 086 (I.S.S. = 17) een 52-jarige man. Een gesloten, comminutieve, hoge femurschachtfractuur links in segment 1 en 2 is behandeld met een 12 mm Küntscherpen, na opboren van de mergholte en cerclage. Na zeven jaar heeft hij bif lang lopen pljn in het been. Er bestaat geen hoekstand, wel $45^{\circ}$ exorotatle. Patient heeft hier weinig klachten van. Hij is al jaren weintg actief wegens een ernstige leveraandoening en daarom is deze afwijking geaccepteerd.

Patłènt 087 (I.S.S. $=20$ ) is een 20 -jarfge vrouw. Een open, dubbele femurfractur links in segment 1 en 4 is behandeld met een 11 mintscherpen. lir 1 s geen hoekstand, we1 $40^{\circ}$ exorotatie. 12 Jaar na het ongeval vertelt z⿺j na lang werken moe te $z i j n$ in het betreffende been. Een röntgenopname van de knie toont geen arthrose. Gezien haar leeftijd is een osteotomie geadv $\mathbb{H}$ seerd.

De endge patiënt uit de groep behandeld met Kaessmann/cerclage, patiënt 139 (I.S.S. 16), is eert man van 50 jaar. Hij loopt een scerk comminutieve gesloten femurschachtfractuur rechts op in segment $2 \mathrm{t} / \mathrm{m} 7$, die is behandeld met Kaesmann/cerclage. Maast de exorotatie van $40^{\circ}$ toont het been $4^{\circ}$ valgus en $11^{\circ}$ recurvatie. Bovendien is er een botlengteverlies van $3,5 \mathrm{~cm}$. Drie jaar later klaggt patiënt over erngtige knleklachten. Op de röntgenfoto van de knle is een versmalde laterale gewrichtsspleet te zien met tekenen van beginnende arthrose. De functle van knie en heup zijn goed. Deze patiënt is een deroterende osteotomie geadviseerd. 
7.3.2. Functionele resultaten

De behandeling van patienten wet een fenurschachtfractuur, is gericht op volledig herstel van de functle.

In het na-onderzoek van de patiënten uit deze serie, ts de functie beoordeeld aan de hand van: 1. looppatroon; 2. kniefunctie; 3. heupfunctie.

\subsubsection{Looppatroon}

Het looppatroon is niet afwijkend indien de paslengte links en rechts gelijk is, het been nomaal vol belast wordt en de lichaams-as bij het lopen in voor/achterwartse richting vertical verloopt. Er word ook op een exorotatiestand van de voet gelet.

Tabel 30 geeft de afwijkingen weer van het looppatroon bij de verschillende groepen. Tussen haakjes zijn de patienten vermeld, warvan het afwijkend looppatroon geheel of gedeeltelijk werklaard kan worden door begeleidende letsels of pre-existente afwijkingen.

Tabel 30.

Loopyarcoon.

\begin{tabular}{|c|c|c|c|c|}
\hline beoardeding & $\begin{array}{l}\text { Kunt scher } \\
(\mathrm{a}=67)\end{array}$ & $\begin{array}{l}\text { Kaes soum } \\
(\pi=28)\end{array}$ & $\begin{array}{l}\text { Kaessmann } \\
\text { cerclage: } \\
(n-22)\end{array}$ & $\begin{array}{l}\text { totiand } \\
(n=117)\end{array}$ \\
\hline normatal & 5.8 & 20 & 16 & 94 \\
\hline af why ghend & $3(\mathbb{H})$ & $8(1)$ & $3(1)$ & $14(9)$ \\
\hline vote fir exorocatite & 6 & - & 3 & 9 \\
\hline
\end{tabular}

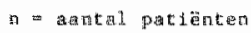

Van de 117 patiënten warvan gegevens beschikbaar zijn, blifkt na behandeling $80 \%$ een nomal looppatroon te vertonen, de owerige $20 \%$ toont afwijklingen in staplengte of loopt met het been in exorotatiestand.

Niet bij de telling betrokken zijn de 12 overleden patiënten, de acht patiënten die buiten het na-onderzoek vallen, én patient met een amputatie en één patiènt met onvoldoende gegevens over het looppatroon. Bij de vier patiënten met dubbelzijdige fracturen is slechts én patient met een normall looppatroon.

.3.2.2. Khotis van de knie

Ter beoordeling van de kniefunctie zijn drie parameters gebruikt:

1. motiliteit van het kniegewricht,

2. stabiliteit van het kniegewricht,

3. omvang van het bovenbeen.

Tabel 31.

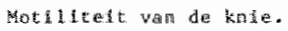

\begin{tabular}{|c|c|c|c|c|}
\hline mok111tedt & $\begin{array}{l}\text { Kuntocher } \\
(n=67)\end{array}$ & $\begin{array}{l}\text { Kasestanin } \\
(n=29)\end{array}$ & $\begin{array}{l}\text { Kaesamann } \\
\text { cerchage } \\
\text { (n w } 22 y\end{array}$ & $\begin{array}{l}\text { totaal. } \\
(n=118)\end{array}$ \\
\hline not然的 1 & 63 & 23 & 19 & 105 \\
\hline beperke & 4 & 6 & 3 & 13 \\
\hline
\end{tabular}

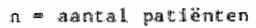


1. Motllitelt wan het knlegewricht.

De motllitelt van de knle is een moellijk te hanteren parameter, daar deze bil patienten met en Eemurschachtfractur zeer duidelijk wordt beinvloed door begeleldende letgels van knie en onderbeen an de homolaterale zijde. Tabel 31 lat de patienten met en zonder beperkte kniemotiliteit zien. De beweeglijkheld van de knie wordt als beperkt beschouwd indien er een flexlebeperking van $20^{\circ}$ of meer bestat bij normale extensie. Indien de sotextensie niet volledig $1 \mathrm{~s}$, wordt dit als afwilkend beschouwd.

De 12 overleden patienten, vier patienten warvan geen gegevens op dit punt te verkrljgen zijn, ë̉n amputatiepatiënt en patiënten met dubbelzijdige fracturen worden niet meegeteld.

Van de patienten met een beperkte beweeglijkheid wordt de ernst wan de bewegingsbeperking weergegeven in tabel 32 .

Tabel 32 .

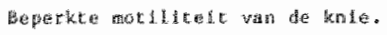

\begin{tabular}{|c|c|c|c|c|}
\hline $\begin{array}{l}\text { mothledes- } \\
\text { theperkng }\end{array}$ & 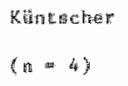 & $\begin{array}{l}\text { Kine gatation } \\
(n=6)\end{array}$ & 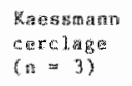 & $\begin{array}{l}\operatorname{tactan} n \\
(n=13)\end{array}$ \\
\hline $20^{\circ}$ & $y$ & 1 & 3 & 7 \\
\hline $30^{\circ}$ & - & $x$ & - & - \\
\hline $40^{\circ}$ & 1 & 3 & - & 4 \\
\hline $50^{\circ}$ & - & - & $\cdots$ & . \\
\hline $60^{\mathrm{o}}$ & - & - & - & - \\
\hline $30^{8}$ & - & 2 & - & 2 \\
\hline
\end{tabular}

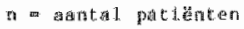

Van de vier patiënten behandeld met een Küntscherpen hebben twee patiënten tevens een homolaterale patellafractuur. Eén patiënt heeft naast een femurfractuur ook een homolaterale tiblaplateaufractuur. De andere patiënt heeft een homolaterale tibiafractuur.

Van de zes met een Kaessmannpen behandelde patiënten met motiliteltsverlies van de knie, hebben drie patiënten een homolaterale tiblaplateaufractuur, een patient een homolaterale eminentiafractuur en éen patiënt een homolaterale tibiafractur.

Twee met cen Kaessmannpen behandelde patiënten hebben een beweglngsbeper$k \mathrm{l} n g$ wan meer dan $70^{\circ}$. De eerste patiënt (016) is een man van 44 jaar. Hij 1. een multitratuapatient (I.S.S. = 30) met een geslaten, dubbele femurschachtfracturx links in segment 1 en 8 , een homolaterale, open tibiafractuur en een instablele bekkenfractuur. Nu 15 jaar later heeft hij een ernstige arthrose van de knie.

De tweede pattënte $(106)$, is een vrouw van 83 jaar (I.S.S. $=20$ ). Naast de gesloten femurschachtfractuur rechts in segment 8 heeft zij een homolaterale tibialateaufractur. Bif het na-onderzoek blijkt zij drie jaar later een ernstige gonarthrose te vertonen.

Blj de drie net Kaessmann/cerclage behandelde patiënten, die een motiliteltsverlies tonen, komen geen begeleldende letsels voor die voor dit verlies mede bepalend zljn geweest.

Van de 13 patienten warbij een motlliteltsverlies van de knie 1 s opgetreden, heeft een begeleldend letsel in negen gevallen bijgedragen aan het ontstaan van de bewegingsbeperking. 
Van de vier patiënten met dubbelzijdige fracturen heeft patient 031 (I.S.S. = 21), behandeld met een Kaessmannpen, een verschil in motiliteit van $40^{\circ}$ ten opzlichte van de andere kant. Patiënt 094 (I.S.S. $=25$ ), behandeld met een küntscherpen, heeft een verschil in motiltteit van $20^{\circ}$. De overige twee patiënten met een bilaterale fractur hebben geen varschil in motilitelt van het linker en rechter kniegewrlcht.

2. Stabilitelit van het kniegewricht.

of schoon knieklachten bijna in eenderde (28\%) van de gevallen voorkonen, blijkt slechts én patiënt duidelijke instabiliteitsproblemen van de knie te hebben. Deze 83-jarige vrouw (patiente 106; I.S.S. $=20$ ) is behandeld met een Kaessmannpen voor een dwarse femurschachtfractur in segment 8. Als begeleidend letsel heeft zij tevens een homolaterale tibiaplateaufractuur.

3. Onvang van het bovenbeen.

De toestand van de bovenbeensmusculattur is gemeten door de ontrek van het bovenbeen $15 \mathrm{~cm}$ boven de mediale gewrichtsspleet te bepalen. Wvenals de motiliteit van de $\mathrm{knie}$, is de omvang van het bovenbeen een moeilijk te hanteren parameter, daar zoveel andere oorzaken quadricepsatrofle kunnen geven (Kootstra 1973). De overledenen, de vier patiënten thet bilaterale femurschachtfracturen en de patienten met begeleidende homolaterale letsels zijn miet meegeteld.

In tabel 33 wordt een overzicht gegeven van de omvang van het bovenbeen fin centimeters wergeleken met de niet gefractureerde zijde.

Tabel 33.

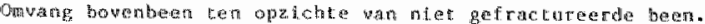

\begin{tabular}{|c|c|c|c|c|}
\hline \multirow{2}{*}{$\begin{array}{l}\text { Ohny ang } \\
\text { bovanbean }\end{array}$} & Künt seher & Kaess. Smann & Kacssman & $\operatorname{coc} 5.3 \mathrm{H}$ \\
\hline & $(m=57)$ & $(n=24)$ & $(0=20)$ & $(n a x$ and \\
\hline
\end{tabular}

\begin{tabular}{|c|c|c|c|c|}
\hline-5 & - & 2 & - & 2 \\
\hline-4 & L & - & or & 1 \\
\hline-3 & 3 & 1 & - & 4 \\
\hline-2 & 7 & 2 & 5 & 14 \\
\hline-1 & 25 & 4 & 4 & 18 \\
\hline 19 & 21 & 11 & 7 & 3 \\
\hline-1 & 17 & 2 & 2 & 17 \\
\hline+2 & 2 & 1 & 2 & 5 \\
\hline 4 & - & - & - & - \\
\hline+4 & - & 1 & - & 1 \\
\hline
\end{tabular}

ก

Uit deze tabel blifkt dat 21 (21\%) van de 101 meegetelde patientem een quadricepsatrofle heeft van $2 \mathrm{~cm}$ of meer.

De gegevens over motiliteit, stabiliteit en splerfunctie worden gecombineerd in tabel 34. De kniefunctie wordt gestoord genoend indien er een. motiliteitsverschil van meer dan $20^{\circ}$, een quadricepsatroffe van meer dan 2 cm of een verlies van stabiliteit bestaat. De twalf overleder patiënten. vier patiẻnten waarvan geen gegevens beschikbaar zijn, Eén amputatdepa tiënt en de vier patiënten met een dubbelzijdige femurfractuur worden als onbekend meegeteld, over een totaal van 139 patiënten. 
Tabe1.34.

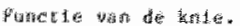

\begin{tabular}{|c|c|c|c|c|}
\hline f artate & $\begin{array}{l}\text { Kunterber } \\
\{\text { th } 7 \mathrm{~g})\end{array}$ & 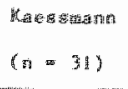 & 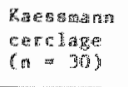 & 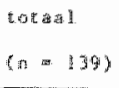 \\
\hline ongestersed & 53 & 22 & 15 & 89 \\
\hline gets tor & 1.5 & 7 & 7 & 29 \\
\hline onblakend & 11 & 2 & y & 2.) \\
\hline
\end{tabular}

n a a a

ULt deze gegevens blljkt, dat 29 van de 89 patiënten ( $32 \%$ ) na een femurschachteractur functleverlies van het knlegewricht heeft. Gezlen de vele factoren, dle naast de femurschachtfractur van invloed zijn op de kniefuncte, kunnen deze tabellen niet meer dan een lndruk geven over de invloed van de femurschachtfractuur op de kniefunctie.

7.3.2.3. Motiliteit san de heup

Het onderzoek van de heupfunctie levert in vergelijking met de knie minder beperkingen op. Tabel 35 geeft een overzicht van de beweeglijkheid van het heupgewricht. De motliteit wordt als normaal beschouwd als de beperking minder dan $20^{\circ}$ is bij abductie, adductle, endo- of exorotatie.

Tabel 35.

Mot llitelt: wam de heup.

\begin{tabular}{|c|c|c|c|c|}
\hline mothltedt & $\begin{array}{l}\text { Kunt soher } \\
(\mathrm{n}=6 \mathrm{G})\end{array}$ & $\begin{array}{l}\text { Kaess shatam } \\
(x+29)\end{array}$ & $\begin{array}{l}\text { Kagsand } \\
\text { corclage } \\
(\text { m }=23)\end{array}$ & $\begin{array}{l}\text { rotand } \\
(n=116)\end{array}$ \\
\hline romatal & 60 & 25 & 18 & 103 \\
\hline beperkt & $4\langle 2\}$ & $4(2)$ & $5(2)$ & $13(6)$ \\
\hline
\end{tabular}

$n$ :actural partionten

De 12 overleden patiënten, acht niet onderzochte patiënten, één amputatiepatfënt en twee patiënten met onvoldoende gegevens zijn hiexbij niet meegeteld. Een overicht van het verldes in motilitelt van het heupgewricht wordt gegeven th tabel 36.

Blj de thet Küntscherpen behandelde patienten worden twee patiënten aangetroffen met beweglngsbeperklngen op basils wan arthrose.

In de Kaesmangroep betreft het een patient die een ernstig motiliteitsverlles heeft op basis wan een begeleidend letsel en een patient met een ernstige coxarthrose.

Bij de Kaessmann/cerclage patienten betreft het eenmal een patient met een pre-axistente slechte heupfunctie en én patiënt met een coxarthrose. Van de 13 patienten met een motiliteftsverlies in het heupgewricht is dit in zes gevallen opgetreden ten gevolge van pre-existente afwijkingen of begeleldende letsels.

7.3.3. Complicaties

Een complicatie verstoort het proces van diagnose, behandeling, genezing en nabehandeling. Ernstige complicaties zoals infectie, gestoorde consolidatie, ernstig verilies van functie, komen slechts bij $7 \%$ van de patiënten voor. Toch heeft het merendeel van de patiënten één of meerdere minder 
belangrijke complicaties doorgemakt, samenhangend met de behandeling van de femurschachtfractuur. Daarnaast konen complicaties van algemene aard voor. Tot de minder ernstige complicaties samenhangend met de behandeling van de femurschachtfractur worden gerekend: het mislukken var primaire ingestelde conservatieve therapie, het missen van begeleidende letsels en problemen bij de operatie.

Tabe1 36.

\begin{tabular}{|c|c|c|c|c|c|}
\hline $\begin{array}{l}\text { Pac. } \\
\text { nar. }\end{array}$ & $\begin{array}{l}\text { Fine semer } \\
(n=4)\end{array}$ & $\begin{array}{l}\text { Eat. } \\
\text { nar. }\end{array}$ & $\begin{array}{l}\text { Kaesstann } \\
\left(\begin{array}{lll}\text { (x) } \\
\text { 4 }\end{array}\right)\end{array}$ & $\begin{array}{l}\text { Pats. } \\
\text { ner. }\end{array}$ & $\begin{array}{l}\text { Raesgunann } \\
\text { cerclage } \\
(a=5)\end{array}$ \\
\hline 038 & $\begin{array}{l}\text { endoroctide } \\
-20^{\circ} \text { arthrose }\end{array}$ & 031 & 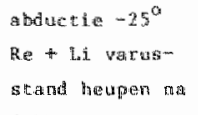 & $0 \mathscr{Z}_{4}$ & 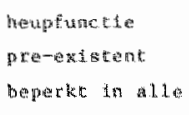 \\
\hline 069 & $\begin{array}{l}\text { alle richeingen } \\
\text { beperke }\end{array}$ & & $\begin{array}{l}\text { dubthell zi jatge } \\
\text { collunifracture }\end{array}$ & & rleht lngen \\
\hline 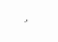 & & & alls begel atdent & 048 & Elaxte $30^{\circ}$ \\
\hline \multirow[t]{2}{*}{121.} & $\begin{array}{l}\text { alle rlichtingen } \\
\text { beperkt }\end{array}$ & & 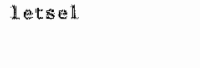 & & beperkt. \\
\hline & ernetige arthrose & 034 & $\begin{array}{l}-20^{\circ} \text { be pretke } \\
\text { endorotate }\end{array}$ & 059 & $\begin{array}{l}\text { andorotation } \\
-20^{\circ}\end{array}$ \\
\hline \multirow{2}{*}{128} & & 106 & $\begin{array}{l}\text { zeer ernstige } \\
\text { arturese }\end{array}$ & 097 & itexie $-20^{\circ}$ \\
\hline & & 137 & $\begin{array}{l}-20^{\circ} \text { beperkte } \\
\text { endorotatie }\end{array}$ & 138 & $\begin{array}{l}\text { In alle rich- } \\
\text { ingen beperkt: } \\
\text { arthrose }\end{array}$ \\
\hline
\end{tabular}

Problemen bij de operatie bestaan uit het niet bereiken van rotatiestabiliteit, moeilijkheden bij het inslaan van de pen, accepteren van een slechte stand van de fractuur, of uit het achterlaten van osteosynthese materiaal na een poging tot verwijderen daarvan. Complicaties van algemene aard bestaan ut trombo/embolische complicaties, luchtweg- en urineweginfecties.

In de volgende tabellen wordt een overzicht gegeven van de complicaties. Gezien het retrospectieve karakter van deze studle kumnen aan de compl1caties bij de verschillende behandelingsmethoden geen vergaarde conclugles verbonden worden.

\subsubsection{Infeetie}

In de literatur worden infecties die optreden na een osteosynthese onderverdeeld in oppervlakkige en diepe infectles. Een oppervlakiclge infectle is een wondstoornis, die gepaard gat met locale of algemene ontstekingsverschijnselen, mar niet leidt tot een posturamatische osteitis. Bij een diepe infectie is dit latste wel he geval. In deze studie wordt diepe infectie gedefinieerd als een ontstekingsproces in het operatiegebled van een osteosynthese, dat meer dan vier weken duurt. Aangezlen oppervlakkige wondstoornissen door de verschillende artsen in de medische status zeer verschillend worden weergegeven, is het niet mogelijk deze te bespreken. Tabel 37 laat een overzicht zien van de diepe infecties in de verschillende patientengroepen. Tussen hakjes staat het aantal open fracturen. 
Tabel 37.

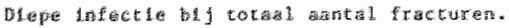

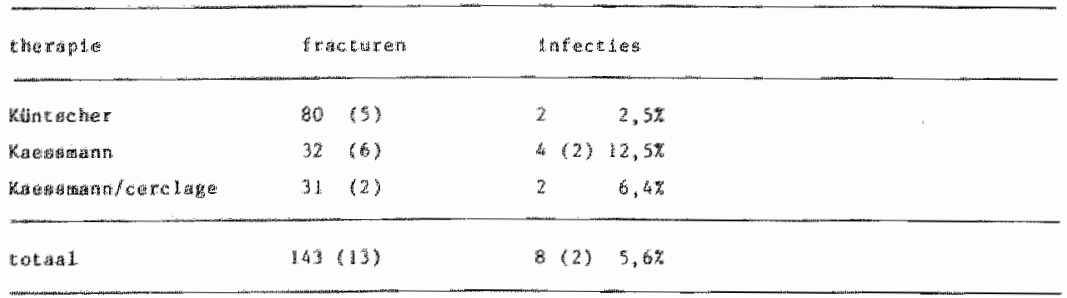

Geen enkele patient overleed binmen twee maanden na het ongeval. Daarom zijn de overleden patiënten in de tabellen over infectle meegeteld.

B1 $j$ de 13 open fxacturen tonen twee fracturen $(15,3 \%$ ) in de Kaessmanngroep een diepe infectle. Bij de 130 gesloten fracturen is bij zes patiênten $(4,6 \%)$ een diepe infectie opgetreden.

Tabel 38 en 39 geven een overzlcht van het voorkomen van diepe infecties bif open en gesloten gereponeerde fracturen.

Tabel 38.

by epe lafectie bif open gerepangerde frocturen.

\begin{tabular}{|c|c|c|c|}
\hline ther tiple & $\begin{array}{l}\text { aancal. } \\
\text { fractorera }\end{array}$ & $\begin{array}{l}\text { open } \\
\text { repostete }\end{array}$ & $\begin{array}{l}\text { Infectle mas } \\
\text { open repositie }\end{array}$ \\
\hline Kint scher & 80 & $46(57 \%)$ & $2(4,3 \%)$ \\
\hline Kate sf mann & 32 & $15(67 \%)$ & $16,6 \%)$ \\
\hline Kä g:mamn/cerclage: & $3 \sharp$ & $31(100 \%)$ & $2(6,4 \%)$ \\
\hline cotand & 443 & $92\left(86 c_{0}\right)$ & $5(5,4 \%)$ \\
\hline
\end{tabular}

Tabei 39.

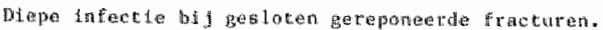

\begin{tabular}{|c|c|c|c|}
\hline 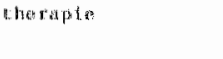 & 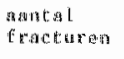 & 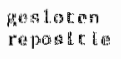 & $\begin{array}{l}\text { Linfoct le na jo- } \\
\text { aloter repositide }\end{array}$ \\
\hline 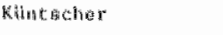 & 80 & $34(43 \%)$ & - \\
\hline What a & 33 & $17(53 z)$ & $3(17,68)$ \\
\hline 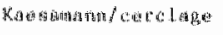 & 31 & - & - \\
\hline [0勘的 & 443 & $51(36 x)$ & $3(5,8 \%)$ \\
\hline
\end{tabular}

Bif de open reposities treedt $\ln 5,4 \%$ van de gevallen een diepe infectie op. Gesloten repositie gaat in $5,8 \%$ samen met een diepe infectie. Een duldelijk verschil met betrekking tot het voorkomen wan diepe infecties tussen belde groepen is er niet. Een verklaring voor het hoge infectiepercentage van de gesloten gereponeerde, met Kaessmannpen behandelde patiënten, kan nlet gegeven worden.

Opboren van de mergholte kan samengan met een grotere kans op infectie, doox het toegenomen aantal handelingen, de beschadiging van de vascilari- 
satie en beschadiging van het weefsel door de warme-ontwikkeling ten gevolge vam de wrijving tussen bot en boor.

De relatie tussen opboren en infectie is weergegeven in tabel 40 .

Tabe1 40 .

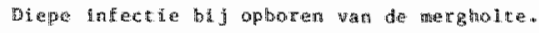

\begin{tabular}{|c|c|c|c|c|}
\hline therede & $\begin{array}{l}\text { atatal } \\
\text { Eractaten }\end{array}$ & opboren & $\begin{array}{l}\text { dofectete ma } \\
\text { opboren }\end{array}$ & $\begin{array}{l}\text { intertion } \\
\text { yomat } \\
\text { ophoret }\end{array}$ \\
\hline
\end{tabular}

\begin{tabular}{|c|c|c|c|c|}
\hline Küntscher & 80 & $79(99 \%)$ & 2 & 0 \\
\hline Kaessmang & 32 & $20(638)$ & 2 & 2 \\
\hline Katssmanm/cerclage & 31 & $17(55 z)$ & 2 & 17 \\
\hline coeas & 143 & $116(81 \%)$ & 5 & 2 \\
\hline
\end{tabular}

Van de acht patiënten met een postrramatische osteltis zijn zes patiënten gesaneerd door aanvullende behandelingen. Van de overige twee patiënten is een mannelijke multitraumapatiënt (092) van 72 jaar met een $\mathbb{I}$.S.S. wan 33 , 88 dagen na het ongeval ten gevolge van sepsis overleden. Patient 104, een 38-jarige man (I.S.S. = 9) met een gesloten spiralfractuur in segment 5 en 6, heeft een chronische posttraumatische asteitis met recidiverende fistels. De fractuur is na open repositie en opboren, gefixeerd met een Kaesmannpen en cerclage. Deze patiënt verricht nu al jaren zonder klachten regelmatig zijn werk als bouwvakker.

\subsubsection{Vertraagde consolidatie}

Van vertraagde consolidatie wordt gesproken indien acht maanden na het ongeval klinisch en röntgenologisch geen tekenen van consolidatle worden gevonden (Dencker 1963, Kootstra 1973).

Klinische tekenen wan afwezige consolidatie zijn abnormale beweeglijkheid, asdrukpijn, zwelling en roodheid.

Afwezige consolidatie wordt röntgenologisch gekenmerkt door de afwezigheid van doorbouw in de fractuurspleet, al of niet in combinatie met ongestructureerde, periostale callusvorming. Het slulten van de mergholte kan bij intramedullaire osteosynthese niet als symptoom gebrulkt worden (Kintescher 1957. Weber 1973, Charnley 1974). Penbreuk als teken van gestoorde consolidatie is in deze patiëntenserie émaal gezlen (Hunter 1982).

Tabel 41 .

Wertragde consolidatide in de werchillende groegen.

\begin{tabular}{|c|c|c|c|}
\hline thetaple & $\begin{array}{l}\text { aratedi } \\
\text { fracturen. }\end{array}$ & $\begin{array}{l}\text { vertrangde } \\
\text { totad } 1\end{array}$ & $\begin{array}{l}\text { consolifiatib } \\
\text { gemfecter ro }\end{array}$ \\
\hline Kuntecher & 180 & - & - \\
\hline Kaessmants & 32 & $2(4.2 \%)$ & $1(3,1 \%)$ \\
\hline Raessmatar/cerelage & 11 & $3(9,6 \%)$ & $1 \quad(3,2 \%)$ \\
\hline totaal & 149 & $5(3,5 \%)$ & $2(1,3 x)$ \\
\hline
\end{tabular}


Tabel 41 geef een overzlcht van de patienten met een vertragde consolidatle en var het antal van deze patiěnten, dat tevens een diepe infectie heeft.

Uit tabel 41 wordt duldelijk, dat bij de met een Küntscherpen bebandelde patienten geen vertraagde consolidatie gezien is. Twee patienten ult de Iizet een kaessmanneta behandelde groep, en drie patienten ut de kaessinam/cerclage groep tonen vertraagde consolidatie.

Bif de met eer Kassinampen behandelde patienten betreft het:

Patient 016, een man van 44 jaar, multitraumapatiënt (I.S.S. $=30$ ), heeft als letsel onder andere een dubbele, gesloten femurschachteractur links, In segment 1 en 8 . De fractur fordt 1 in eerste instantie gestabiliseerd met een gebogen Kuntscherpen, ingebracht vanult de mediale condy 1 van het femur. Er ontotaat een vertraagde consolidatie van de proximale fractuur, dle ná ển jaar wordt behandeld met een Kaessmannpen. De fractuur is hierop, ondanks een periode met diepe infectie geconsolldeerd.

Patuent 022, een 20-jartige jongen ( $I . S . S .=9$ ), loopt als bromfietser als erig letsel een gesloten, korte schuine femurschachtfractuur rechts op in segment 6. De fractuur wordt gestabliliseerd inet een kaessmampen. Wegens toenemende hoekstand en vertraggde consolliatie wordt deze fractur in een andere kliniek na thien manden gestabiliseerd met een A.0.-compressieplat. Hierop treedt snelle consolidatie op.

In de Kaessman/cerclage groep wordt vertraagde consolidatle gezien bij:

Patiënte 059, een huisvrouw van 22 jaar (I.S.S. $=22$ ). $\mathrm{Zij}$ loopt ten gevolge van een auto-ongeval bilateral een gesloten femurschachtfractur op. Rechts een korte schulne fractuur in segment 7 en B, 1inks een dwarse fractuur met driehoeklg fragment in segment 5 en 6 . Beide fracturen zijn gestabiliseerd met een Kaessmannen en cerclage. Rechts consolideert de fractuur in zes weken. Links ontstaat een vertraagde consolidatie met infectie. Na 16 manden wordt deze fractuur opnieuw gestabiliseerd met een Küntscherpen, na opboren van de mergholte, waarna de fractur zonder infectie consolddert.

Patiènt 098 , is een 26-jarige man (I.S.S. = 16) bij wie ten gevolge van eer auto ongeval een gesloten cominutieve femurschachtfractur links in de gegmenten $2,3,4$ en 5 ontstat. Na stabildsatie met een Kaessmannpen en cerclage, consolideerd de fractur niet. Na $1 \frac{1}{2}$ jaar wordt de pseudarthiose gestabiliseerd met men Kütscherpen, die na $1 \frac{1}{2}$ jaar breekt. Na vier Jaam, wordt met en verder opgeboorde kintscherpen en antirotatieplat de fractur tot consolidatie gebracht.

Patient 138, een man van 69 jaar (I.S.S. = 9), wordt als fietser door een atuo aangereden en loopt hlerbij een gesloten, dwarse femurschachtfractuur links op in segment 5. Bij open repositie wordt een fissurux gezien, zodat de fractur gestabiliseerd wordt met Keessmanpen en cerclage. Na zes maanden is er geen enkel teken van consolldatle zichtbaar, zodat de kaessmanpen vervangen wordt door een kintscherpen met opboren van de mergholte. Zeven maanden later wordt wegens matige doorbouw van de fractuur een botspaan aangebracht. Na $2 \frac{1}{2}$ jaar is de fractuur geconsolideerd.

In tabel 42 wordt een overzicht gegeven van blijvende klachten bij patiënten na een femurschachtfractuur. De patiënten zijn in drie groepen 
ingedeeld: patiëmten zonder klachten, met atige klichten en met erngtige klachten. Ernstige klachten worden gedefinieerd als zodanig ernstge bew zwaren, dat bij de witoefening van dagelijkse bezigheden altijd hinder ondervonden wordt. Matige klachten worden gedefinfeerd als berwaren die slechts optreden bij sportbeoefening of bij meer dan normalie belasting. Opvallend veel patiënten blijken geringe klachten te hebben in de tin wan snelle vermoejdheid van het been, pljn ter hoogte van de trochanter major en pijaklachten in de knie. Minder dan de helft van de patiënten vertelt in het geheel geen klachten te hebben. De groep patiënten met ernstige klachten toont altijd anatomische afwijkingen bij fysisch-diagnostisch of röntgenonderzoek.

Tabe1. 42.

Kacheren.

\begin{tabular}{|c|c|c|c|c|c|}
\hline theraple & $\begin{array}{l}\text { annal } \\
\text { pant tenters }\end{array}$ & $\begin{array}{l}\text { klacht } \\
\text { geon }\end{array}$ & ten & artatis & on bekend \\
\hline Kuntscher & 78 & 32 & 28 & 3 & 15 \\
\hline Kines smantm & 31 & 9 & 1.0 & 2 & 10 \\
\hline Kaesisman eerclage & 30 & 8 & 10 & 3 & 9 \\
\hline cotaal & 139 & 49 & 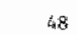 & 3 & 34 \\
\hline
\end{tabular}

Als onbekend zijn gekenmerkt: de twalf overleden patiënten, de vier patiënten die geen vragenlijst hebben ingestuurd en de 18 patienten met begeleidende homolaterale letsels.

\subsubsection{Klachten in relatie tot anatomische of functionele afwijkingen en compliaties}

Uitgaande van de reeds gemaakte Indeling van de klachten wordt nagegaan bij hoeveel patiënten klachten samengaan met ernstige anatomische of functionele afwijkingen en complicaties.

Onder ernstig verlies van functie wordt verstaan:

1. motiliteitsbeperking van de knfe van meer dan $20^{\circ}$, ontbreken van slotextensie, quadricepsatrofte van meer dan $2 \mathrm{~cm}$, verlies van stabiliteit,

2. motiliteitsbeperking van de heup van meer dan $20^{\circ}$ in een bepalde richting,

3. gestoord looppatroon.

Onder een ernstige anatomische afwiliking wordt verstaan:

1. botlengteverlies van meer dan $2 \mathrm{~cm}$,

2. exo- of endorotatie van meer dan $20^{\circ}$,

3. as-afwijkingen van meer dan $10^{\circ}$.

Technische problemen bij het utvoeren van de operatie bestaan uit:

1. moejlijkheden bij de repositie: losraken van fragmenten, te lat opmerken van fissuren, uitwal van de nervus peroneus, accepteren van een slechte stand van de fractuur en rotatiedeformiteit.

2. problemen bij het inslaan van de pen: perforatie van de corticalls, vastlopen van de pen, onjuiste keuze van de mat van de pen.

3. het niet bereiken van oefenstabiliteit.

4. problemen bif het verwijderen wan het osteosynthese materlaal, het moeten achterlaten van cerclage of een deel van de spandoorn. 
5. problem met de dwarschroef van het Kassmannsyteen.

Hen overzicht, van het aantal patienten waarbij technische problemen bij het ultworen van de operatie zijn opgetreden, wordt gegeven in tabel 43.

Tabel 4 "3.

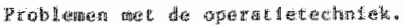

\begin{tabular}{|c|c|c|c|c|}
\hline 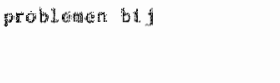 & $\begin{array}{l}\text { keinctioter } \\
(x+12)\end{array}$ & 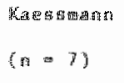 & 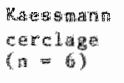 & tot 20 . \\
\hline 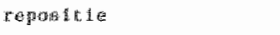 & 6 & $\$$ & 1 & 6 \\
\hline Inst.ün fin de pen & 6 & $\mathbb{1}$ & 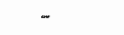 & 5 \\
\hline 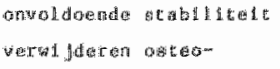 & 5 & 2 & $z$ & 9 \\
\hline 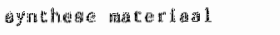 & 1 & 2 & 3 & 6 \\
\hline dwar resisch to to & - & 1 & - & 1 \\
\hline 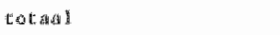 & $\mathrm{l}_{i} 4_{4}$ & 7 & 6 & 27 \\
\hline
\end{tabular}

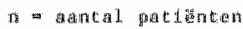

Bij 25 (18\%) van alle patiënten $z 1 j n$ samen 27 complicaties opgetreden tijdens het utvoeren van de osteosynthese.

Problemen met begeleidende letsels zijn het niet tijdig diagnostiseren van deze letsels of het voorkomen van ernstige complicaties bij de behandeling wan deze letsels.

In de met een Küntscherpen behandelde patiëntengroep komen zes patiënten woor met problemen van een begeleidend letsel. Bij twee patiënten is een zenuwletsel laat vastgesteld. Bij drie patiënten $z 1 \mathrm{jn}$ begeleidende fracturen aanvankelifk niet herkend, eén fissuur van de homolaterale tibia-, een homolaterale collum femortsfractuur en één awulsiefractuur van de mediale condyl van het femur. Bij één patiënt is een onderbeensamputatie verricht wegens een ernstige septische complicatie.

Bij vier patienten behandeld met een Kaessmampen zijn problemen gevonden.

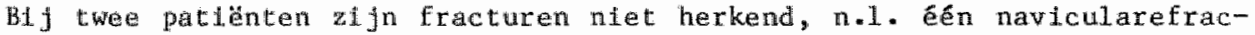
tuur van de hand en éfn bilaterale fractur van het collum femoris. Bij Eén patiërt is na afslufting van de primalre behandeling een deroterende osteotonle wan de thbla verrlicht, wegens primaire osteosynthese met veel exorotatie. Eenmal is een parese van de gluteus musculaturar aanvankelijk untet onderkend.

Bij thee met Kaessana/cerclage behandelde patiënten is eemaal een letsel van de nervus ischiadicus gemist en Eenmal een pre-existente osteitis van de tibia.

Len owerzicht van alle complicaties opgetreden blj de verschillende typen osteosynthese wordt gegeven in tabel 44 .

Niet alie 85 patienten die cen of meerdere complicaties hebben doorgemakk, houden blijvend klachten. Ongekeerd zijn er ook patiënten die klachten blijven houden, zonder dat er aantoonbare restverschijnselen zifn. On hier lnztcht in te verschaffen is het totale patientenbestand onderverdeeld in vier categorieën: 
1. patiënten zonder klachten,

2. patiënten met matige klachten,

3. patiënten met ernstige klachten,

4. patienten warbij het onbekend 1 s of er samenhang bestat tussen de klachten en de femurschachtfractuur.

Tot de laatste categorie behoren de patienten die geen vragenformulier hebben ingevuld, de patiënten warbij de klachten mogelijk $2 i j n$ apgetreden wegens een begeleidend letsel en de patiënten die overleden zijn.

Tabe 144.

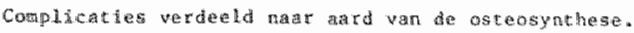

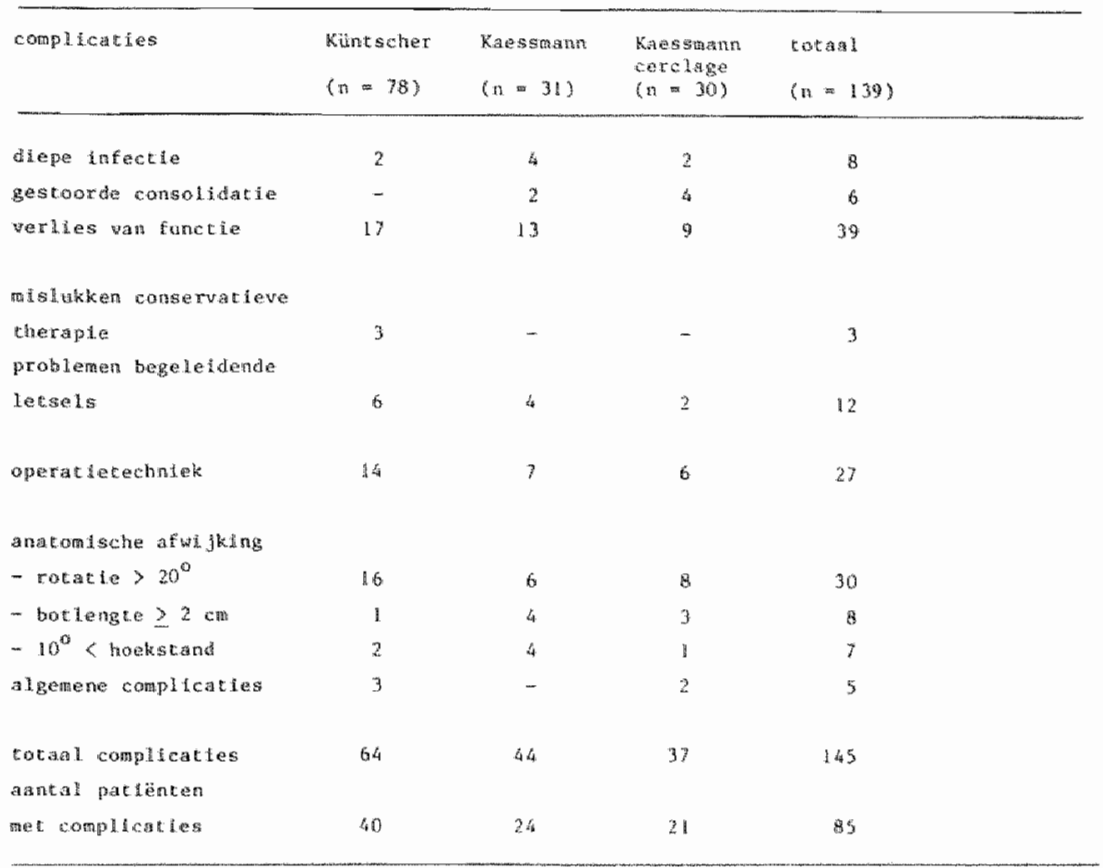

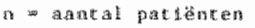

De relatie tussen klachten, anatomische en functonele afwijkingen en doorgenakte complicaties is weergegeven in flguur 18 .

Van de 105 patënten zijn er witeindelijk 28 (27\%) zonder klachten, zonder complicaties en zonder resterende anatomische of functionele afwijkingen genezen. Uit alle gegevens blijkt, dat het genezingsproces voor een patiënt met een fractuur van de femurschacht gepaard gaat wet een onverwacht groot aantal problemen. Bij 49 patiënten zijn er geen klachten, terwijl. bij 21 van hen wel een anatomische of functionele afwijking is angetoond, of zich een complicatie heeft voorgedan. 
Figur 18. Kiachten.

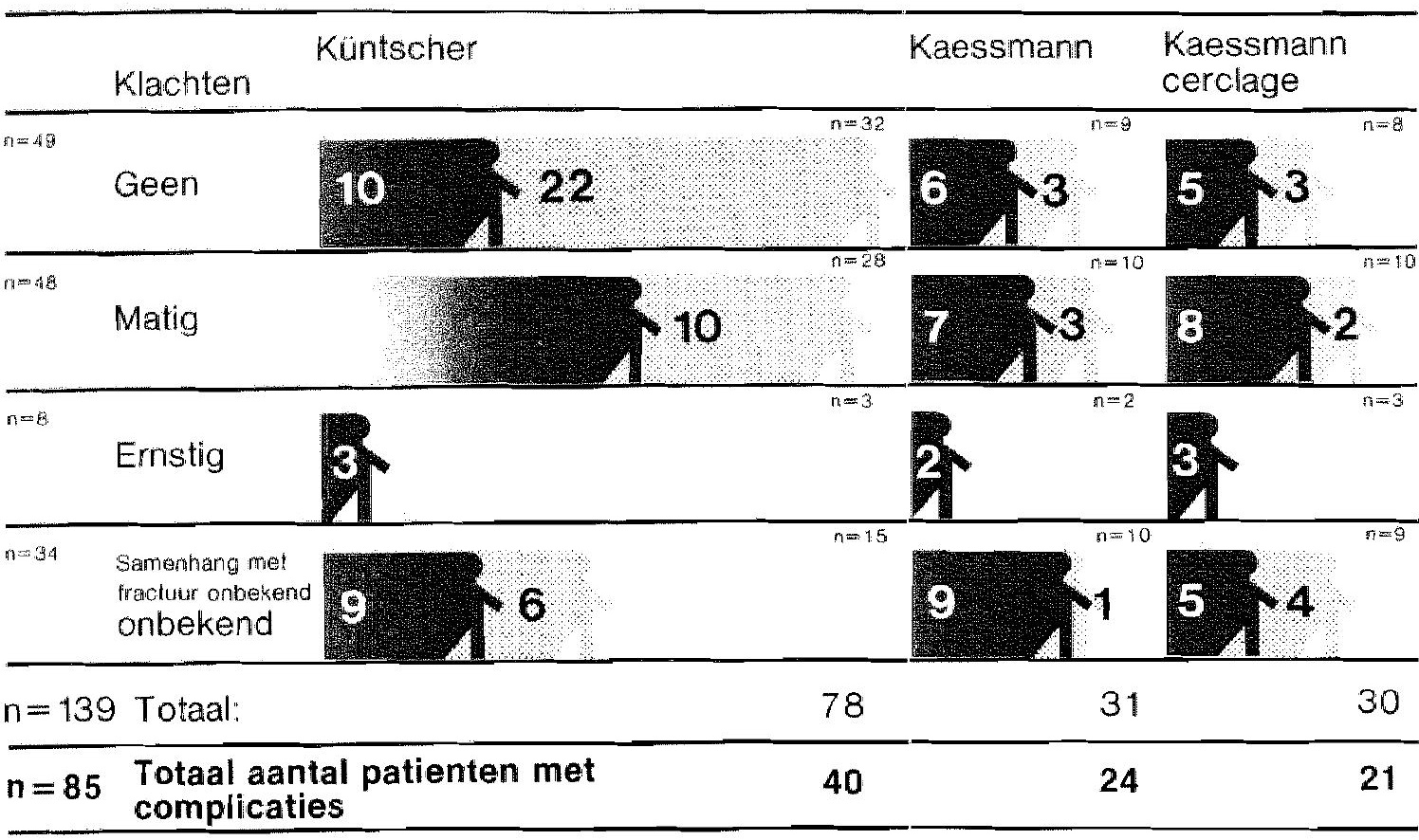

aantal patienten met anatomische,

functionele afwijkingen en complicaties 


\section{Niet intramedullair behandelde fracturen van de femurschacht}

In de periode van 1976 tot 1981 , is het relatief grote antal kleinere problemen bij de operatieve behandeling van patienten met een femurschachtfractuur de reden geweest, dat ook andere therapievormen zijn anderzocht. De gunstige resultaten gemeld uit de V.S. bij vroeg functionelle, niet operatieve therapie van patiënten met een femurschachtractur heeft in onze kliniek geleid tot de toepassing van deze therapie bij een beperkt aantal patiënten (Perkins 1958, Hardy 1976, 1982, 1983, Mc Coy 1976, crotwell 1978).

On een indruk te krijgen over de warde van vroeg functionele theraple ten opzichte van intramedullaire osteosynthese worden de behandelingsresultaten van de 25 niet operatief behandelde patiënten besproken. War mogelljk worden de resultaten van de niet operatief behandelde patienten vergeleken met de intramedullatr behandelde patiënten.

De gemiddelde leeftijd van de 19 manen en zes vrouwen uft deze groep bedraagt 32,7 jaar. Twee patiënten zijn overleden. Het interval tussen ongeval en na-onderzoek bedraagt 3,6 jaar $(1-6$ jaar). In 19 gevallen (76\%) is de femurschacht fractuur ontstaan ten gevolge van een verkeersongeval. Bij de 25 niet operatief behandelde patiënten is in 14 gevallen de fractuur behandeld met draadextensie op een Braunse slede. In elf gevallen is Perkinstractle gevolgd door vroege mobilisatie met behulp van een "thigh lacer" toegepast. De "thigh lacer" bestaat uit een afneembare plastic koker om het bovenbeen. Door de spieractiviteit bij het oefenen ontstat een drukverhoging, die een repositie en stabiliteit van de fracturdelen bewerkstelligt.

8. 1. BEGELEIDENDE LETSELS

De Injury Severity Score (I.S.S.) van de begeleldende letsels is weergegeven in tabel 45 .

Tabel 45 .

Injury severticy sicore.

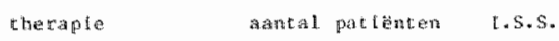

\begin{tabular}{|c|c|c|}
\hline conseryaties & 14 & 22,2 \\
\hline$P \in$ r & 11 & 12,8 \\
\hline fneramedull 1 ax & 139 & 14,9 \\
\hline
\end{tabular}

De hoge I.S.S. blj de conservatief behandelde pattëmten vrdt verklatrd door de beide overleden patienten (T.S.S. 41 en 57).

Tabe 1.46.

Gemidda de opnamedur *

\begin{tabular}{|c|c|c|}
\hline thererpie & gancal patiönten & opndmedutin $\pi$ \\
\hline conservatidef & 9 & 87 diagen \\
\hline Perklngeractide & 10 & 56 dagen \\
\hline Intranedullatr & 135 & 69 dragen \\
\hline
\end{tabular}




\subsection{OPHAMEDUUR}

De opnamedur van de pattênten met ega niet intramedullair behandelde Eractur van de femuchacht is teergegeven in tabel 46 .

Bij de berekentng var de opnameduur zijn patienten waarbij ten gevolge van een begeledderid letsel, of een niet met de femurschachtfractur samenhangende complicatle de opnamedur wordt belrvloed, niet meegeteld.

\section{3. VERLOOP VAN DE CONSOLIDATTE}

In tabel 47 wordt het gemiddelde interval, tussen het angeval, het onbelast, partiél, en wolledig belast lopen en de consolidatie in weken weergegeven.

label 147.

Verlaop war da congolidaten

\begin{tabular}{|c|c|c|c|}
\hline Weletert tot & $\begin{array}{l}\operatorname{congerutat} \\
(n=12)\end{array}$ & $\begin{array}{l}\text { Petcinatracte } \\
\text { (a) } 11 \text {. }\end{array}$ & 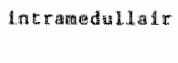 \\
\hline ondelaget lopen & 11,1 & 5,6 & 2,7 \\
\hline pacteded belact lopen & 14,1 & 9,6 & - \\
\hline valledilis belaget lopen & 27,5 & 14,8 & 16 \\
\hline röntgan. comal oldate & 1.9 .7 & 13,4 & 15 \\
\hline
\end{tabular}

n. andial patentan

In tabel 47 zijn de overleden patiënten niet meegeteld. De gegevens over de intramedullair behandelde patiënten zijn verkregen uit tabel 22 .

8. 4. ANATOMISCHE RESULTATEN

8.4.1. Afrifkingen in botlengte

Tabel 48.

Bat leagcentersch1 .

\begin{tabular}{|c|c|c|}
\hline Long tover chil & $\begin{array}{l}\text { conservatlef } \\
(n \text { m } 8)\end{array}$ & $\begin{array}{l}\text { Petklnstractie } \\
(n+11)\end{array}$ \\
\hline 0 c斾 & $y$ & it \\
\hline$=1$ Cดा & 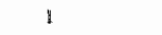 & 3 \\
\hline$-2 \mathrm{~cm}$ & 5 & $E_{4}$ \\
\hline$-9 \mathrm{~cm}$ & - & 1 \\
\hline-4 cta & - & - \\
\hline$-5 \cos$ & 1 & - \\
\hline
\end{tabular}

$n$ aratiol tersecuten

In de conservatief behandelde groep heeft $75 \%$ van de patienten een botlengteverlies van 2 cm of meer. Blj Perkinstractie heeft $45 \%$ van de patienten een botlengteverlies van ten minste $2 \mathrm{~cm}$. De in onze kliniek toegepaste nlet operatleve behandelingsmethoden blijken derhalve ln een hoog percentage tot een belangrijk verlies van botlengte te voeren.

De fracturen van de overleden patiënten, patiënten die elders zijn nabehandeld of rarvan onvoldoende röntgenmateriaal ter beschikking staat, zijn buiten de telling gelaten. Bij de met Perkinstractie behandelde 
patienten is het lengteverlies mogelijk wat minder.

De twee patienten met en lengteverlies van 3 en 5 cr zijn zeer gespierde jonge vollassenen.

8.4.2. Hoekstanden

4.2.1. Afuigkingen in het fromtale vlak

De afwijkingen in het frontale vlak zijn weergegeven in tabe1 49 .

Tabel 49.

Roekstanden in tae frontale wiok.

\begin{tabular}{|c|c|c|}
\hline boekstand & $\begin{array}{l}\text { conservatidef } \\
(n=9)\end{array}$ & $\begin{array}{l}\text { Perkinstractie } \\
(n=9)\end{array}$ \\
\hline
\end{tabular}

\begin{tabular}{|c|c|}
\hline $5^{\circ}$ & 4 \\
\hline $10^{\circ}$ & ॥ \\
\hline $15^{\circ}$ & 2 \\
\hline
\end{tabular}

yalgasstand

$5^{2} \quad 2$

$10^{\circ}-1$

w atral Eracturen

3.4.2.2. Afwijkingen in het sagittale viak

Tabel 50.

Hoakstanden in het sagititale viak.

\begin{tabular}{|c|c|c|}
\hline hoekstiand & $\begin{array}{l}\text { conservatiof } \\
(m=9)\end{array}$ & $\begin{array}{l}\text { Perklastractee } \\
(n=9)\end{array}$ \\
\hline
\end{tabular}

$\begin{array}{lcc}\text { ancecarwatie } & \\ 5^{\circ} & 2 & 2 \\ 19^{\circ} & - & 3 \\ 15^{\circ} & - & 1 \\ 20^{\circ} & 1 & 1\end{array}$

\begin{tabular}{lcc} 
recurwate & 2 & 1 \\
$5^{\circ}$ & 2 & - \\
$10^{\circ}$ & 1 & 1 \\
$1.5^{\circ}$ & 2 & - \\
$20^{\circ}$ & - & - \\
$25^{\circ}$ & 1 & - \\
$30^{\circ}$ & 1 & \\
\hline
\end{tabular}

to col anatial frareuren

De meest exnstige hoekafwijkingen worden gezien in de conservatief behandellie groep. 
Bij de berckening van de hoekstanden zijn de fracturen yan de patienten warvan brulkbaar fotomaterial ter beschikking staat, meegeteld.

8.4.3. Rotatie-af Jikingen

Tabel 51.

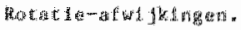

\begin{tabular}{|c|c|c|}
\hline Tolatede & $\begin{array}{l}\text { congervatief } \\
(t \rightarrow 7)\end{array}$ & $\begin{array}{l}\text { gerelinat ractede } \\
(n=s)\end{array}$ \\
\hline
\end{tabular}

exporate

$\begin{array}{ccc}5^{63} & 4 & 4 \\ 10^{6} & 1 & - \\ 20^{6} & 1 & 1 \\ 30^{68} & 1 & -\end{array}$

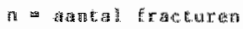

De fracturen van overleden patienten en van patienten die elders nabehandeld zijn, worden butten beschow wing gelaten. Endorotatie is niet wargenomen.

8.5. FUNCTTONEEL RESULTAAT

Tabe1 52.

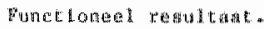

\begin{tabular}{|c|c|c|}
\hline gat HA telt & $\begin{array}{l}\text { conservacidet } \\
(\mathrm{n}=9)\end{array}$ & $\begin{array}{l}\text { Perkinstratche } \\
(n=7)\end{array}$ \\
\hline
\end{tabular}

kntie

meer als $20^{\circ}$ beperkt

onbegerke

1

heup

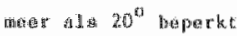

onbegertikt

9

๓ * mantal fracturen

Bij Ecn patiënt (512) (I.S.S. = 17), in de Perkinsgroep, een man van 22 jaar met eer cominutieve femurschachtfractuur links in segment $1,2,3,4$ en 5 en een homolaterale callumfracturr, is ondanks aanvankelijk zeer goede beweeglifkheld van het kniegewricht, de musculus vastus intermedius In de Eractuur vastgegroeld. Na operatief losmaken van de spler is de knfemothiteft van deze patient $100 \%$ hersteld.

Een conservatief behandelde patiënt (519) (I.S.S. = 32), een 21 -jarige man met een korte schuine femurschachtfractuur rechts met losse fragmenten in seguent 6, heeft knieklachten ten gevolge van een arthrosis praecox. De fractuur wan het femur is geconsolideerd met $5 \mathrm{~cm}$ verkorting, $15^{\circ}$ varus en $30^{\circ}$ recurvatie. Al s begeleidend letsel heeft patiënt een homolaterale open onderbeenfractuur met ernstig weke delen letsel. De verwonding van het 
onderbeen, waarvoor een fixateur externe wordt aangelegd, geneest na verschillende debridements en spongiosaplastiek. Door dit begeleidend letsel is de behandeling van de fenurschachtractur niet optimal geweest.

\subsection{COMPLICATIES}

0ok na net-operatieve fracturbehandeling worden infecties pseudarthrosen, vertragde consolidatie, refracturen, ernstige anatomische afwijkingen en pijnklachten gevonden.

8.6.1. Infectie

In de conservatief behandelde groep patiënten is bij patiënt 520 , een 14jarige jongen (I.S.S. $=16$ ) een diepe wondinfectie opgetreden, die na behandellng met antibiotica ulteindelijk zonder chronische posteraumatische osteItis is genezen.

8.6.2. Stoornissem in de consolidatie

Vertraagde consolidatie en pseudarthrosevorming zijn bij de niet-operatief behandelde patiënten niet opgetreden. Bij vier patiënten is echter een refractuur ontstaan.

Patiënt 520, een 14-jarige jongen (I.S.S. = 16) heeft een open, kotte schuine femurschachtfractuur rechts in segment 4 en 5, gecompliceerd door een diepe wondinfectie. Na 8 weken conservatief behandelen ontstaat bij mobiliseren een refractuur. Deze fractuur is na 20 weken geconsolideerd in goede stand, zonder tekenen van postraumatische osteitis.

Bij patiënte 524, een 46-jarige vrow (I.S.S. = 14) met een korte schulne femurschachtfractur rechts met driehoekig fragment in segment 4 en 5 , ontstat na 12 weken conservatieve behandeling een refractuur. Een Jaa na het trauma is de fractuur röntgenologisch in $13^{\circ}$ varus, $17^{\circ}$ antecurvatie, $20^{\circ}$ exoratatiestand en met $2 \mathrm{~cm}$ verkorting geconsolideerd. Patient heeft rug- en voetklachten. De anatomische afwljkingen worden binnenkort gecorrigeerd.

In de met Perkinstractie en "thigh lacer" behandelde groep van 11 patignten is bij twee patiënten een refractuur opgetreden.

Bij patient 509, een drugsverslaafde 24-jarige man ( $1 . S . S .=16$ ), met een spiralfractur links in segment $1,2,3$ en 4 ontstaat 12 weken na het eerste ongeval, door een val met de flets een refractuur. Deze refractur. is in een ander ziekenhuls met succes conservatief behandeld.

Bij patiënt 503, een 17-jarige jongen (I.S.S. $=20$ ), met een dwarge fenurschachtractur rechts, met driehoekig fragment in segment 4, ontataat thuis 10 meken na het ongeval, tijdens partiëel belast lopen door een migstap een refractuur. Deze refractuur wordt behandeld met een kütscherpen. De patient kan na drie weken, partieel belast lopend, het ziekenhuls verlaten. De refractur is 19 weken na het eerste trama, geconsolideerd net $100 \%$ Eunctie, goede asrichting, zonder rotatie en $2 \mathrm{~cm}$ verkorting.

8.7. COMBINATIE VAN GEGEVENS OVER PATIENTEN MET KLACHTEM, ANATOMISCHE AFWIJKINGEN EN COMPLICATIES

In de conservatief behandelde groep van 14 patiënten, zat jn drie patienten (21\%) zonder klachten, complicaties, ernstige anatomische afwijkingen of functieverlies genezen. Hierbij zijn dezelfde criteria gehanteerd als in hoofdstuk 7. In de met Perkingtractie en "thigh lacer" behandelde groep 
yan elf patienten zijn drie patienten (27\%) zonder klachten, functieverlies, conplicaties of ernstige anatomische atwijkingen genezen.

Tabel 53.

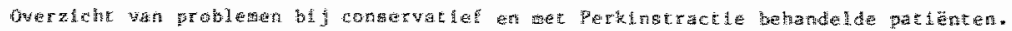

\begin{tabular}{|c|c|c|}
\hline corapledeated & 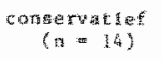 & $\begin{array}{l}\text { Perktnstract te } \\
\qquad(n=11)\end{array}$ \\
\hline dfepes Intecte & 1 & - \\
\hline 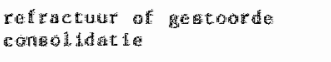 & 2 & 2 \\
\hline 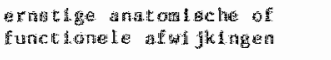 & 6 & 4 \\
\hline 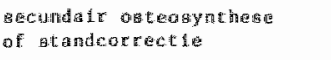 & 2 & $\sharp$ \\
\hline gegcoord lipopatroon & $a_{4}$ & 3 \\
\hline probleminen met drakdextensie & - & 言 \\
\hline overledera & 2 & - \\
\hline
\end{tabular}

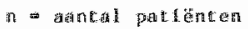

\subsection{DISCUSSIE}

De groep patiënten die niet operatief behandeld 1 , is te klein om uit de betreffende gegevens betrouwbare conclusies te kunnen trekken. Dok zijn de gegewens over deze patlënten en hun fracturen niet met elkaar te vergelijken.

Uit de I.S.S. en gemiddelde leeftijd blijkt, dat in de conservatief behandelde groep meer oudere patiënten voorkomen (gemiddelde leeftijd 32,7 Jaar) thet meer begeleldende letsels (gemiddelde I.S.S. 22,3). In de Perkinsgroep komen meer jongere patiënten (gemiddelde leeftijd 20,8 jaar) met minder begeleidende letsels (gemiddelde I.S.S. 12,8) voor.

Ondanks de conclusie van Dencker (1964), dat aan conservatieve behandeling van femurschachtfracturen de voorkeur gegeven moet worden, blijkt wel wit de behandelingsresultaten van deze 25 patiënten, dat conservatieve behandeling zeker niet zonder problemen is. Vooral bij patienten met ernstige homolaterale begeleidende letsels wordt een slecht eindresultat bereikt. De fonge patiënten 516 en 519 die nast de femurschachtfractur een open homolaterale cominutleve onderbeenfractur met ernstig weke delen letsel hebben, tonen wat betreft hun femur een slecht eindresultaat.

Indien elders op het 1 ichaam wondstoornissen optreden 1 s osteosynthese van de femurschachteractuur niet meer mogelifk. In deze gevallen $1 \mathrm{~s}$ het van belang, bly de eerste opvang maast osteosynthese van het onderbeen, ook osteosymthese van het femur te verrichten. Indien toch voor conservatieve therapie van het femur wordt gekozen moet hieraan ook de volle aandacht wordt besteed.

ook vroeg functionele conservatleve theraple blifkt problemen te geven. slechts eenderde van de met Perkinstractie behandelde patiënten geneest zonder klachten, complicaties, ernstige anatomische afwijking of verlies van functie.

De vroeg functionele therapie, is gezien de resultaten bij elf patiënten, vooral goed toepasbaar bij coöperatieve adolescenten met een femurschachtfractuux. Toepassing bij zeer gesplerde patiënten leidt tot verkorting (WInquist 1.980$)$. 


\section{Voor- en nadelen van de verschillende methoden van intramedullaire osteosynthese}

In dit hoofdstuk worden de problemen beschreven, die kunnen ontstaan bij de intramedullaire osteosynthese van het bovenberen, zoals die zijn ver gegeven in de literatur en zoals die in dit ondergoek naar voren zin gekomen.

9.1. HET PRE-OPERATTEVE ONDERZOEK

9.1.1. Diagnose van pre-existente ziekten

Alvorens tot osteosynthese van een femurfractur over te gaan, moeten pre-existente afwijkingen bekend zijn. De aanwezigheid van exnstige ziekten of organfunctiestoornissen bepalt mede de indicatie tot en de keuze van de osteosynthese.

9.1.2. Diagnase van begeleidende letsels

De algemene toestand wan de patiënt moet vór de osteosynthese stablel zijn. De aanwezigheid en uitgebreidheid van begeleidende letsels moet onderzocht worden. Daartoe is het bij multitraumapatienten noodzakel1jk controle uit te oefenen op respiratie, circulatie, centrale en perifere zemuwfunctie, $\mathrm{Hb}$, stolling en nierfunctie. Deze controles moeten aangevuld worden met een serie bloedgasanalysen en röntgenopnamen van thorax en abdomen. Zonodig worden ernstige intra-abdominale letsels uitgesloten door het verrichten van een "abdominal tap" * On begeleidende letsels van collum femoris en bekken uit te sluiten moet bij patiẻnten met een fractuur van het bovenbeen steeds een röntgenonderzoek van het bekken worden verricht. Bij twee van de bestudeerde patiënten zijn in totaal drie collumfracturen aanvankelljk onopgemerkt gebleven. Bij enige verdenking op letsels wan het overige bewegingsapparaat wordt gericht aanvullend röntgenonderzoek verricht.

De behandeling van ernstige thoracale en abdominale letsels heeft voorrang. Schedelletsels vormen, na uitsluiting van ernstige intracranlële bloedingen, over het algemeen geen contra-indicatie voor osteosynthese. Gedurende de eerste 72 uur na het trauma moet de patiënt nauwlettend gevolgd worden om wroege symptomen van "resplratory distress" te ontdekken.

\subsubsection{Fysische diagnostiek}

Het behoeft geen betoog, dat bij ledere femurschachtfractuur anderzocht moet worden of er letsels van bloedvaten en zenuwen bestaan. Deze preoperatieve controle 1 s onontbeerlijk an ernstige problemen te voorkomen.

Vatletsels worden niet altijd tijdig ontdekt (Winter 1978). Perifere vaathetsels dienen voor het bereiken van een optimal resultaat binnen 6 uur na het ongeval behandeld te worden. B11 het vaststellen van een nervus peroneus uitval na een osteosynthese wegens een verse fracturu, kan de vraag of deze wóbr de operatie reeds bestond, nlet steeds beantwoord worden. Bij de bestudeerde patienten is bij twee patienten een tijdelijke uitval van de nervus gluteus superior en bij ë́n patient een blijwend nervus peroneus letsel primair niet gediagnostiseerd.

Bij een electieve osteosynthese na enige dagen is het belangrijk de toestand van de huid in het operatiecerrein te onderzoeken en tevens na te gaan of de patient elders geinfecteerde wonden heeft.

\subsubsection{Röntgenonderzoek}

Een van de meest voorkomende fouten is het accepteren van technisch wiet optimaal uitgevoerd röntgenonderzoek. Ook het onvoldoende nauweurj.g interpreteren van de röntgenopnamen komt frequent voor. 
Herdoor cunnen fissuren in het femur worden gemist. Bil het opboren of bij het 1 islaan van de megpen breken deze fragmenten uit en kan met de pre-operatief gekozen methode van osteosynthese geen stabiliteit worden berelkt (Wellex 1973). In deze patientenserie zijn blj twee patienten fisguren over het hoofd gezien.

De anwezigheld wan een femurgchachtractur mag niet de reden zifn, dat andere letsels niet ontdekt worden. Het samengaan van de femurschachtractuur tet fracturen van collum, patella, tibia, voet of acetabulum wordt nogal eens over het hoofd gezien. Het is belangrijk aan de hand van anamnestische gegevens te reconstrueren welke weg de geweldsinwerking van het trauma door het llcham heeft afgelegd om aan de hand hiervan begeleidende letsels op te sporen. Aan de hand van het fysisch-diagnostisch onderzoek en anarnestische gegevens moet pre-operatief ultvoerige röntgendiagnostlek worden verrjcht. Omdat onderzoek van de kniebanden pre-operatef niet mogelijk is, dient dit peroperatief na elke osteosynthese van het femur ultgevaerd te worden. In de door ons bestudeerde patiënten is dit onderzoek niet steeds verricht, wardoor mogelijk een aantal bandletsels niet gediagnostiseerd is.

Bljkomende letsels worden in principe in dezelfde zitting behandeld.

Begeleldende letsels zijn niet primair gediagnostiseerd bij:

Patiënt 010: een 20-jarige man (I.S.S. = 25) met een femurschachtfractuur links, warblj en homolaterale fractur van de tibia, zonder dislocatie, niet gediagnostiseerd is. De patient is primair conservatief behandeld. Er zijn geen nadelige consequenties voor de patiënt ontstaan.

Pateint 027: een 16-Jarige man (I.S.S. = 9) met een femurschachtfractuur links. Bif deze patiënt is een fractuur van de mediale condyl van het femur niet opgemerkt. Dit letsel heeft aanleiding tot knieklachten gegeven, zodat later het retinaculum van de patella is gekliefd.

Patiënt 031: een mannelijke multitraumapatiënt, 26 jaar (I.S.S. $=21$ ), heeft na een bromfietsongeval een letsel van beide bovenbenen, gepaard gaande met een dubbelzijdige, dwarse femurschachtfractur. Tijdens de osteasynthese met behulp van een Kaessmannen wordt aan de rechter zifde een pertrochantere fractuur opgemerkt, die vervolgens wordt gefixeerd met een cerclagedrad. Aan de andere zijde 1 s een zelfde fractuur onopgemerkt gebleven. Patient is genezen met een ernstige varusstand van beide heupen. Er I 1 middels een valgligerende osteotomie verricht.

Patiénte 091: bij een auto-ongeval heeft deze vrouwelijke, 28-jarige patlënte (I.S.S. $=20$ ) een letsel opgelopen van het IInker been, gepaard gande met een dubbele, tweemal dwarse femurschachtfractuur 1inks. Deze 1 behandeld met een Kaesmannen. De navicularefractuur van de rechter hand 1 onopgemerkt gebleven en patiënte is hlerwoor in tweede instantie conserwatief behandeld.

patient 129: een 28-jarige man (I.S.S. 21) heeft bij een auto-ongeval een dwarse schachtfractuur opgelopen van het rechter bovenbeen (I.S.S. = 21). De fractur is behandeld met een Küntscherpen. Een laterale collumEractuur is onopgemerkt gebleven tot na de osteosynthese van het femur. In tweede instantle is het collum conservatief behandeld met een zweefrekverband. De fractur is in goede stand geconsolideerd, zonder nadelige consequenties voor de patient. 


\subsection{PROBLEMEN BIJ DE INDICATIESTELLIMG}

Bij patiënten waarbif de lengtegroel onvoltoold is, bestat aen contraindicatie voor iedere vorm van intranedullaire osteosymthese, dar door de asteosynthese de nog niet gesioten epifysairschijuen beschadigd worden.

\subsubsection{Kürtscherpen}

Het gebruik van een küntscherpen voor osteosynthese van femurschachtfracturen is slechts mogelijk in de potentiele isthmus, Zoals beschreven in hoofdstuk 5.1.3., is de potentiele isthmus gelegen in dat deel wan de femurschacht waar, na opboren van de mergholte, voldoende cortical bot, boven en onder het niveau van de fracturr overblijft, on elastische inkleming wan een Küntscherpen mogelijk te maken en daarmee stabilitelt te verkrijgen. Wanneer fracturen buiten het gebied van de pocentele isthmus met een kütscherpen behandeld worden, bestat geen enkelle zeterheld over het berelken van stabiliteit. De vorm van de fractuur is eveneens van belang voor de keuze van de osteosynthese. Spiralfracturen en commintieve fracturen zijn door hun vorm ongeschikt om behandeld te worden met osteosynthese volgens het Kintscherprincipe.

Bij 78 van de 139 in Maastricht behandelde patiënten zijn 80 femurschachtfracturen geopereerd met een kintscherpen. Of de ktintscherpen op juiste indicatie is toegepast is af te lezen uit tabel 54.

Tabel 54.

thdicatile Kintscherpen $(n=62)$.

\begin{tabular}{|c|c|c|}
\hline sengrgert & $\begin{array}{l}\text { dwatse en horte } \\
\text { schuine fracturt } \\
\pm \Delta \text {-fragment }\end{array}$ & $\begin{array}{l}\text { splrat }+\Delta \text { fragment on } \\
\text { commatiewe fracturen }\end{array}$ \\
\hline$i$ & 2 & 2 \\
\hline 2 & 4 & 1 \\
\hline 3 & 22 & 4 \\
\hline 4 & 13 & 1 \\
\hline 5 & 7 & 3 \\
\hline 6 & 3 & $m$ \\
\hline 7 & - & - \\
\hline 8 & - & - \\
\hline
\end{tabular}

in and fracturen

Niet meegeteld zijn 18 fracturem, warvan drie bij overleden patiënten, en Een bij een dubbele fractur. Bij 14 patienten kan doordat het femur niet volledig is afgebeeld of er geen ongevalsfoto's ter beschlkking stan, de vorm of plaats van de fractutur niet vastgesteld worden.

Bil de dwarse en korte schuine fracturen, blijkt de Rüntscherpen viffinal (segment 1 en 6) te $21 j n$ toegepast buiten het gebied van de potentielle isthmus, dus bij een onjulste localisatle van de fractuur.

Wat het fracturtype betreft blifkt een kintscherpen bli elf fracturen op onjuiste indicatie te zijn toegepast. In totaal is de Kintscherpen dus bij 16 fracturen $(26 \%)$ op een niet correcte manter gebruikt. Bl. deze 16 fracturen is tweemaal $(12,5 \%)$ een complicatie bif de fracturbehandeling opgetreden. Bij de overige 46 fracturen 15 een dergelijke complicatie in drite gevallen $(6,5 \%)$ opgetreden. 
Ook de fractur "en deux etages" (dubbele fractuur) is over het algemeen minder geschlkt voor osteosynthese met een Kuntscherpen. Bij het gesloten opboren ten behoeve van intramedullalre osteosynthese met een Küntscherpen, bestaat $\mathrm{blj}$ een dubbele fractuur het gewaar, dat door opboren het tussenliggend stuk femur on zijn lengte-as draait en wolledig gedevascularfseerd wordt. Dit gevaar wordt groter naarmate de tussenliggende botcylinder korter 1 s (Schatzker 1980, We11er 1983). Bij een open repositie kan deze complicatie vermeden worden, het wrijleggen van de fractur betekent een aanslag op de vascularisatie van het bot.

In deze serle zijn viff dubbele fracturen voorgekomen. Hiervan zijn drile patiënten 006, 087, 094 met een Küntseherpen behandeld. De duwr tot röntgenologische consolidatie $1 \mathrm{gt}$ met gemiddeld 32 weken bij deze drie patienten duidelijk boven het gemiddelde van 14,9 weken voor de gehelle groep wan patiênten, die zijn behandeld tet een Küntscherpen. Mogelijk bestaat er samenhang met de slechte vascularisatie van het tussenliggende fragment en de lange consolidatieduur. Bij deze drife patiënten zijn bovendien ernatige rotatie-afwijkingen opgetreden, ondat een van de fracturen gelocaliseerd is buiten de potentiele isthmus.

Een femurschachtfractuur in de potentiële isthmus, gecombineerd met een homolaterale collumfractuur is een contra-indicatie voor een intramedullaire osteosynthesie met een Küntscher- of Kaessinannpen. Deze combinatie is driemaal gezlen bij twee patiënten. Bij patiênt 031 en patiënt 129 met een dubbelzijdige femurschachtfractuur is belderzijds de diagnose collumfracturr primalr gemist. Ook hierbij geldt, dat begeleldende letsels mede de indicatie tot intramedullaire osteosynthese bepalen.

9.2.2. Kaessmannpen

De Kaessmannpen geeft stabilitelt door interfragmentaire compressie. In princlpe kan deze pen gebrulkt worden woor alle dwarse fracturen van de femurschacht. Hoewel de rotatiestabiliteit bij gebruik van de Kaessmannpen ten opzichte van de Küntscherpen zesmaal beter 1s, voldoet de Küntscherpen bij dwarse en korte schulne fracturen in de potentiële isthmus uitstekend (Van Straaten 1981). Dwarse femurschachtfracturen buiten het gebied van de potentiële isthmus vormen daarom het indicatlegebied voor de Kaessmannpen. Schuine of comminutleve fracturen kunnen niet behandeld worden met een Kaessmannen alleen. Ook dwarse fracturen warbij fissuren naar proximal 1 of distaal lopen zijn ongeschikt voor osteosynthese met een Kaessmannpen. Dwarse schachtfracturen "en deux etages" vormen, omdat opboren niet nodig 1: eveneens een ind lcatlegebled voor het Kaessmansysteem. Een enkele keer kan dit zelfs met een gesloten techniek geschieden.

Tabe1 55 .

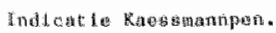

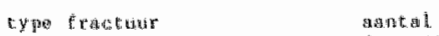

$(n \because 31)$

\begin{tabular}{|c|c|}
\hline 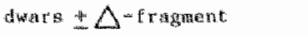 & 17 \\
\hline 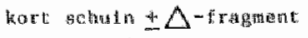 & 10 \\
\hline 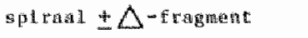 & \\
\hline 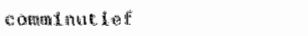 & \\
\hline a u beel. & \\
\hline
\end{tabular}

$\mathrm{n}$ a mantel fracturen 
Twee patientuen met een dubbele fracturir zijn aldus behandeld met een Kaessmannpen. In beide gewallen is het resultat wat betreft de consolidatie van de fractur goed. Bij patient 016 is de Kaessmampen wegens een instabiel gefixeerde dubbele fractuur in segment 1 en 8 met succes toegepast. Bij patiërt 091 is de fractur a 14 weken geconsolideerd. Bij beide patiênten 4 s primair een open repositie verricht.

B1j 31 patiënten zijn 32 Kaessmannpennen ingebracht. On de indicatiestelling te evalueren is bij deze patienten nagegan welk type fracturi is behandeld. Eén fractuur is niet meegeteld, omdat het röntgenmaterial onvolledig is (tabel 55).

Uit deze gegevens blijkt dat twee cominutieve fracturen met een Kaess-mannpen zijn behandeld.

Patiënt 103, een 37-jarige man (I.S.S. = 16) heeft een comminutieve fenurschachtfractuur rechts met groot los fragment in segment 4,5 en 6 . Het is bij deze patiënt gelukt on gesloten een grote maat pen ( $14 \mathrm{~mm}$ ) $1 \mathrm{n}$ te brengen. Consolidatie en klachtenvrij herstel met $100 \%$ functie volgde in 14 weken.

Bij patiënt 109, een 36-jarige man (I.S.S. = 17) is dezelfde techniek toegepast. Deze open commutleve femurschachtfractur rechts, is gelocaliseerd in segment 7 en 8. De fractuur is in 16 weken geconsolideerd.

Patiënt heeft klachten gehouden van een homolaterale tibiaplateaufractur. In beide gevallen is een oud model kaessmannpen toegepast, die meer gefungeerd heeft als een dynamische grendelpen dan als compressiepen.

\subsubsection{Kaessmannpen in combinatie met cerclage}

Bil de Kaessmannpen gecombineerd met cerclage wordt stabiliteit bereikt door interfragmentaire compressie. Het uiteenwijken van de fractuurfragmenten ten gevolge van axlale compressie wordt daarbif opgevangen met cerclagedraden. Spiralfracturen in elk segment van de femurschacht vormen een goed indicatiegebied voor een osteosynthese met Kaessmann/cerclage.

ook comminutieve fracturen met grote vitale fragmenten kunnen op deze wijze behandeld worden. Fracturen die doorlopen buiten het door ons als femurschacht gedefinieerde deel wan het femur, vormen een contra-indicatie voor het gebrulk vam Kaessmann/cerclage.

Tabel 56.

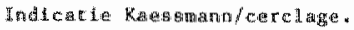

type fracture

$(n=31)$

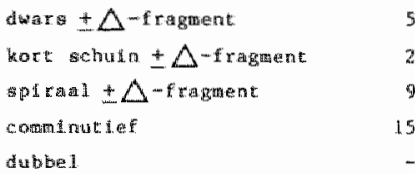

Sh aratal sacturata

Kleine fragmenten mogen geen krachtendragers zijn bij deze methode. Een voorbeeld hiervan is patiënt 059 , waerbij een complicatie is opgetreden, 
doordat een klein fragment gedevasculatiseerd en als krachtendrager is vastgezet met cerclage. Het Eragment 1 s geresorbeerd en heeft zo aanleiding gegeven tot het ontstaan van ingtablifteit en gestoorde consolidatie. B1j 30 patlenten is 31 mal Kaessmann/cerclage toegepast. Ook hier is de indicatestelling onderzocht, doox na te gaan welk type fractuur behandelu 1 is volgens deze methode. Tabel 56 geeft eer overzicht.

Het wijleggen van de fractur en aanbrengen van cerclage bij de vijf dwarse fracturen is een vorm van overbehandeling en betekent een vergroting van het operatierdstco.

Een juiste keuze van de methode van osteosynthese is alleen mogelijk na een nawkeurige bestudering van de fractuur, warbij naast de relatie van de fractutr tot de isthmus van de mergholte, de vorm van de fractuur gedem findeerd moet rorden.

9.3. PROBLEMEN BIJ DE PRE-OPERATIEVE VOORBEREIDING (fIguUr 19)

9.3.1. Problemem bij het inbrengen en verzorgen van de draadextensie

De problemen die men kan verwachten bij het gebrulk van een draadextensie kan men onderschefden in:"

1. problemen bij het inbrengen: laesies van belangrijke anatomische structuren zijn bij de dradextensie door de tuberositas tibiae zeldzaan. Bij het boren van de draad door het distale deel van het femur bestaat meer kans op vaat- en zenuwsletsels.

2. uitscheuren van de Ruschnerdraad uft het bot, wat over het algemeen wordt veroorzaakt door het te oppervlakk1g boren van de draad.

3. Infectle is een probleem, dat zelden optreedt. Door Böhler (1957) wordem zeer ernstige infectles gemeld, eenmal zelfs met dodelijke afloop.

4. zenuwletsels, die vrijwel nooit door het inbrengen van de draadextensie ontstaan. Veeleer worden deze letsels veroorzaakt door tractle aan de zenuwstreng, waarbij uitval van de nervus peroneus het theest frequent wordt waargenomen (Koslowsk1 1962). Mogelijk kan ook een compartimentsyndroom voor het ontstaan van zenuwletsel verantwoordelijk worden gesteld. Dencker (1963) beschrijft 1005 femurschachtfracturen warbij draadextensie is toegepast in 976 gevallen. In $5 \%$ hiervan ontstaan complicaties. Drie patiénten hebben een osteItis gekregen, twee patiënten een zenuwletsel. BL 21 pateienten $4 \mathrm{~s}$ de KLischnerdraad uit het bot gescheurd. Bij 21 andere patienten 1 s een infectle van de weke delen ontstaan. Bij een draadextensie door de tuberositas tibla ziet Dencker in $3 \%$ en bij een draadextensie door het distale femur in $9 \%$ complicaties.

Böhler (1957) is geen voorstander van draadextensie boven de knle, daar hif ten gevolge hierwan ankylose van de knie, anputatie en osteomyelitis met dodelifke afloop heeft wargenomen.

Ook Watson-Jones (1976) adviseert de draadextensies niet door het distale fenur aan te brengen, ondat hij adhaesies in het kniegewricht ten gevolge van infectie langs de Kirschnerdraad vreest. Evenals Böhler waarschuwt hij tegen te langdurige tractie. Böhler vindt tractie gedurende zes weken het maximum. Watson-Jones denkt, dat de oorzaak van beschadiging van het knjegewricht gezocht moet worden in tractie met te veel gewicht.

Miller (1978) bespreekt de problemen van draadextensie bij 43 kinderen. Hij heeft bij 10 kinderen, waarbij in $90^{\circ}$ flexte door de tuberasitas tibiae is getrokken, weel knileklachten en in zeven gevallen radiologisch een luxatle of subluxatle van het kniegewricht gezien. Miller is bij kinderen voorstander van draadextensie door het distale deel van het femur. 


\section{PROBLEMEN BY DE PRE-OPERATIEVE VOORBEREIDING}
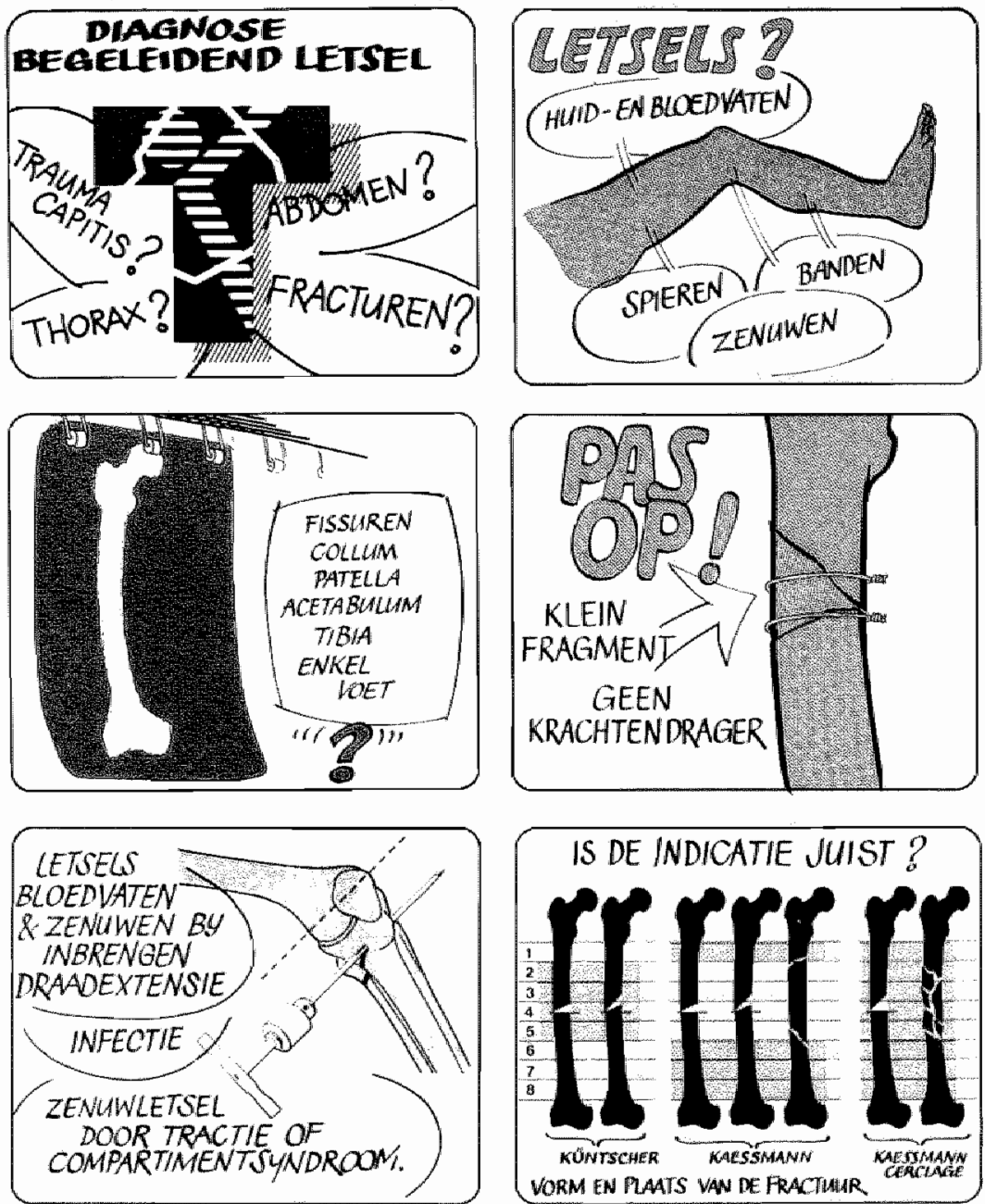
Alg wootbereiding op en intra-medullaire osteosythese wan het femur ontatat door het openen van-de mergholte bij het aanbrengen van een supracondylatre draadextensile largs de kirschnerdraad een verbinding met de buitenwereld. Door de aandezigheid van dit boorkanal ontstaat een verhoging van het infectier $\mathbf{s} 1$ co (Koslowsil 1962). In Maastricht wordt frequent tractle toegepast met behulp wan een "Denhamail", die met een achroefdraad vateit in de laterale corticalis van de tibia en daardoor niet heen en weer kan schulwen. Bif 25 conservatef behandelde patienten hebben wij bif gebrulk van deze "Denhanail" noolt een weke delen infectie of geinfecteerd penkanal gezien.

9.3.2. Problenen bij de verdere behandeling van de patient in tractie

De meest voorkonende fout bij een patiënt die behandeld wordt met draadextensie í onvoldoende contrale van de juiste positie van de patient op een Braunse siede of in een Thomas "splint". Plaatsen war gevar bestaat woor het ontataan van drukplekken moeten regelatig gecontroleerd worden (Watson-Jones 1976). In ieder geval moet de positie van de patiënt zodanig zijn, dat een effectleve vorm van tractie kan worden gehandhaafd. On recurvatle tegen te gaan moet het bovenbeen voldoende steun ondervinden. Om een antecurvatiestand te voorkomen moet de steun over een behoorlijke afstand plaatsvinden. Athankelijk van de plats van de fractuur in de femurschacht moet door de tractie de dislocatienelging, die ontstaat door de aanhechting wan bepaalde splergroepen, worden tegengegaan.

Figuur 20.

\section{PROBLEMEN BY DE BEHANDELING VAN DE PATIENT IN TRACTIE.}
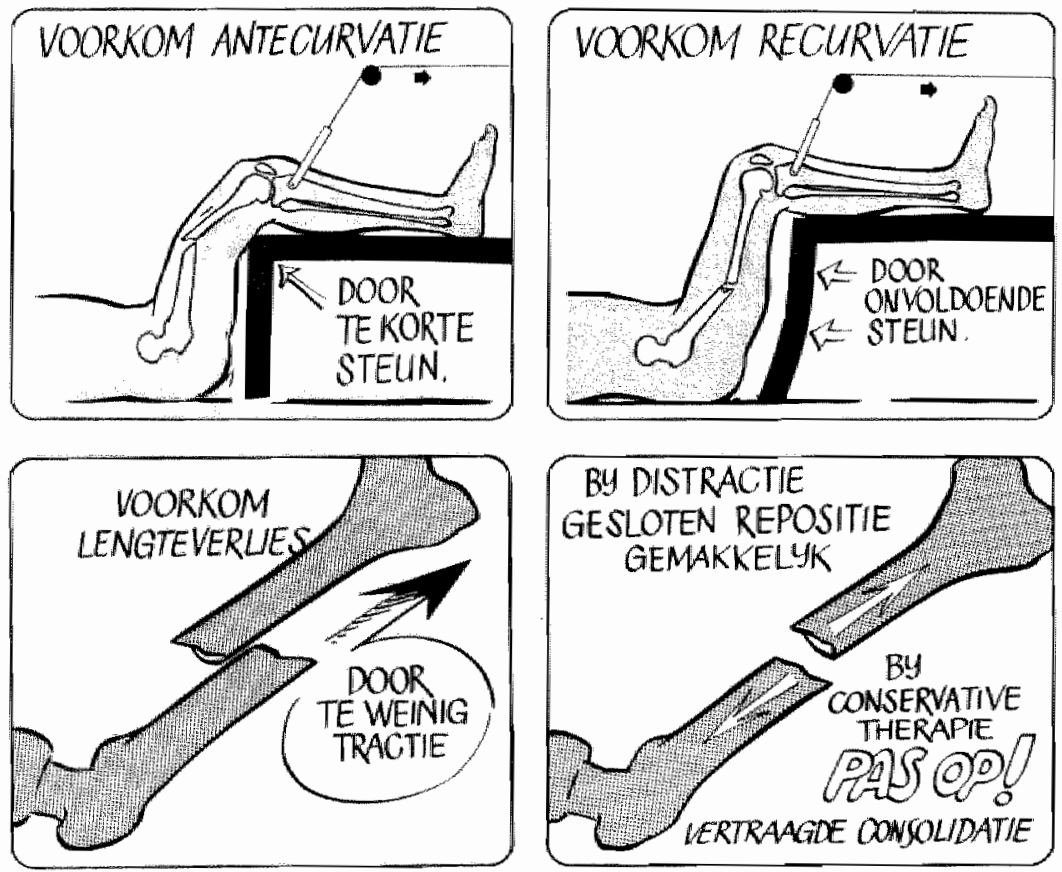

PREOPERATIEF $\rightarrow$ GEHELE PATIENT ONDERZOEKEN NAAR GEINFECTEERDE WONDEN 
Er mag geen verlies van botlengte optreden, daar langer durende verkorting van het femur een gesloten repositie bij de intramedullaire osteosynthese onmogelijk maakt. Ook in onze kliniek wordt een zekere mate van distractie als voorbereiding op een intramedullaire osteosynthese nagestrefd (Koslowski 1962). In ieder geval moet de tractie zodanig ultgevoerd worden dat indien er contra-indicaties voor osteosynthese ontstaan, de behandeIing moelteloos voortgezet en afgemaakt kan worden als conservatleve theraple (figuur 20).

9.3.3. Problemen in de onmiddellijke pre-operatieve fase

Bij patienten die voorbehandeld zijn met draadextensie moet in de periode vóor de operatie een mawkeurige inspectie van het operatieterreln geschieden. Infectie of niet genezen wonden in dit gebied of eldex op het licharm van de patiënt vormen een contra-indlcatie voor operatle. Het scheren van de huid dient onmiddelidjk voorafgande aan de operatie te gebeuren, om te voorkomen dat de toegang naar de fractur doox een gebied met patentiëel geinfecteerde huidlaesies gekozen wordt. Mult itraumapatiënten of patiënten die wegens een ernstig weke delen letsel acuut geopereerd worden dienen uitvoerig onderzacht te zijn. Respiratie en circulatie moeten gestabiliseerd zijn. De behandeling van letsels van thorax en abdomen verdient vaorrang boven de fracturbehandeling. Bij voorkeur worden bij een multitramapatiënt meerdere operatleteams gelijktijdig Ingezet om de operatieduur zoveel mogelijk te beperken (Burri 1982).

9.3.4. Problemen bij de voorbereiding van de intramedullaire osteosynthese

1. Instrumentarium.

a. Alvorens een intrameduliaire osteosynthese te beginnen dient de operateux gecontroleerd te hebben, dat een volledige set mergpennen ter beschikking stat. Het mag niet voorkomen, dat een osteosynthese met een minder bevredigend resultaat wordt beëlndigd ondat de julste mat pen niet a anwezig is.

b. Eer contrôle op het goed functioneren van het benodigde instrumentarium is een vereiste. Boormachines moeten onderhouden en versieten instrumenten tijdig vervangen worden.

c. Röntgenapparatuux is onmisbaar voor de juiste vitwoering van een intramedullaire osteosymthese. Een goede pre-operatieve planning en het beproeven van de juiste apstelling van de röntgenapparatuur, is essentiëel om de osteosynthese tot een goed einde te brengen.

d. De operatie moet uitgevoerd worden op een voor dit doel geschtkte operatiletafel. Aan zeer essentiële zaken al röntgendoorlaabaarheld van en woldoende rulmte rond het operatieterrein moet worden voldan.

\section{Ligging van de patient.}

De positie van de patiënt op de operatletafel moet zodanig zijn, dat de trochanter major , de crista iliaca en de laterale zijde van het bovenbeen vrij zijn. De patient moet zodanig 1iggen, dat er voldoende rulmte beschikbar ls om handelingen als opboren van de mergholte en luslaan van de mergpen ongehinderd te kunnen uitwoeren. Küntscher (1967) beveelt aan de patient in zijligging op de extensietafel te opereren. Grosse en Kempf verrichten de operatie in rugligging op de extensietafel (Vêcsei 1978).

De A. 0.-groep beveelt aan de intramedullatre osteosynthese ult te voeren in zijligging zonder extensietafel (Miller 1977). Het gebrulk van de extensietafel is athankelijk van de patient die behandeld mote worden. Het gebruik ervan bij multitramapatienten brengt vaak met zich mee, dat de patient in aanslulting aan andere operaties, ter behandeling van letsel fo van thorax en abdomen moet worden overget11d. Voor deze patiẹnten $11 j k t$ 
het gebruik van een extensletafel minder aangewezen. Aangezien een extenaitafel hulp biedt bij de repositie, kan hiervan bij electeve operaties nuttig gebruik worden gemakt. Het in juiste positie brengen van een patient vóbr de operatie is een wezenlijk onderdeel wan de operatie en behoort tot de taak van de operateur. Een foutieve ligging zal de operatie bemoellijken, of zelfs omogelijk maken. Bovendien moet worden toegezien op voldoende polstering rond het kniegewricht en de genitalia (Koslowski $1962)$.

\subsection{PROBLEMEN BIJ DE OPERATTE (FIguUr 21)}

Dencker (1964) beschrijft, dat bij een groep van 459 patiënten in $14 \%$ van de gevallen zich technisthe problemen voordoen. De problemen, die kunnen ontstan door het afdekken van de patiënt, gebruilk wan röntgenapparatuur, operten van de rergholte, inbrengen van de voerdraad, opboren van de mergholte en Inslaan van de pen worden hieronder besproken. Bij 25 (17\%) van de 143 in Mastricht behandelde fracturen is tijdens de operatie een technisch probleem gerezen.

1. Afdekcen van het operatieterrein.

Van belang is, dat bij het afdekken van de patiënt een wast schema gewolgd wordt. Hierbij moet rekening gehouden worden met de moblliteit die noodzakelijk is voor het gebrulk wan de röntgenapparatuur. Bovendien moet zodanig afgedekt worden, dat indien een gesloten repositie niet lukt, moeiteloos kan worden overgegaan tot een open repositie. Ook moet met de mogelljkheid tot het verkrijgen van spongleus bot rekening worden gehouden (Weller 1973). On zo weinig mogelijk fouten te maken, zal in iedere chirurglsche klinilek een standaard procedure voor het afdekken moeten worden gevolgd.

\section{Röntgendaborant (e).}

Een absolute vereiste is, dat de laborant(e) die de röntgenapparatuur bediend ervaring en inzlcht heeft in de procedure die tijdens de osteosynthese gevolgd wordt. Wanzelfsprekend moet de röntgenlaborant(e) met betrekking tot het handhaven van de steriliteit gewend zijm aan het werk in de operatiekamer.

3. De toegang tot het mergkanaal.

Het openen van de mergholte is een zeer belangrljke stap. De incisie moet proximal van de trochanter major 1 iggen, in het verlengde van de femurschacht (Küntgcher 1967). Letsel van weke delen dient voorkomen te worden. Na het klieven van de fascia lata wordt de trochanter major gepalpeerd. De fut ste plats om de mergholte te openen is even lateraal en ventral van de cop van de trochanter gelegen (Schawwecker 1981). Deze plaats wordt bepald, door de vorn van het femur. Indien mediall van de top van de trochanter de mergholte wordt geopend, bestaat het gewaar van ernstige beschadiging wan het collum femoris of van de vascularisatie van de femurkop. Bif openen van het heupgewricht kan een artritis ontstaan (Schatzker 1980). Bovendien ontstaat tifdens het opboren nog enige vergroting van de introductieplaats van de pen, zadat een laterale toegang, de kans op beschaduging van het collum femoris verkleilnt. Aangezien het femur een lichte antecurvatle vertoont, zal om een zo recht mogelijk kanaal voor de mergpen te krifgen, de mergholte zo ventraal mogelijk geopend worden. Doordat het proximale fracturfragment in de heup geflecteerd is, kan met de priem ook de corticalis an de dorsalle zijde van het trochantermasslef worden geopend. De voerdraad en uiteindelijk ook de pen komen hierdoor dorsal buiten de mergholte te liggen. Het inbrengen van de priem in de 
juiste richting is van groot belang. Een foutlef gekozen plaats on de mergholte te openen kan tot ultbreken van de pen of zelfs fracturen wan het trochantermassief aanleiding geven. Een intramedullalme osteosynthese kan dan niet meer plaatsvinden.

4. Inbrengen van de boorgeleider.

Madat de mergholce is geopend wordt een van een knop vootzlene voerdraad (boorgeleider) in de mergholte gebracht. De punt van deze voerdragd wordt licht gebogen, zodat bif het opzoeken van de mergholte van het distale fractuurfragment met deze gebogen voerdram beter genanoeuvreerd kan worden (Koslowski 1962, Küntscher 1967, Weller 1973). De 1igging van de boorgeleider moet na het passeren van de fractuurspleet, in het proximale en distale deel van het femur in twee richtingen gecontroleerd worden. De boorgeleider moet centraal in het distale deel van de mergholte $11 \mathrm{ggen}$, omdat daarmee hoekafwijkingen van het boorkanal in het frontale en sagittale vlak worden woorkonen.

5. Het opboren van de mergholte.

Bij het opboren mag nilet te veel kracht gebruikt worden, daar botfragmenten kunnem afbreken, wardoor de kans op stabiliteit verloren gat. In onze serie patiënten is dit tweemal gebeurt (patiënt 003 en 121). Bij hest opboren moeten boren, die in diameter opklimmen wet $0,5 \mathrm{~mm}$ in de juiste volgorde worden gebruikt. Bij gebruik van de kaessmannpen hoeft over het. algemeen niet verder dan $11 \mathrm{~mm}$ opgeboord te worden. Bij oudere patienten met wijde mergholte kan opboren soms achterwege blijven. Indilen de boor afbreekt of vastloopt in de mergholte kan deze teruggehaald worden door het uitslaan van de boorgeleider, die speciaal voor deze complicatie een knop aan het ufteinde heeft. Indien de boorgelelder teruggeslagen wordt en de boor toch proximaal van de fractuur in situ blifft, kan de boorknop met een. Kütscherpen vanuit de fractuur teruggeslagen worden. Een distaal van de fractuur vastzittende boorkop kan voor de pen uitgedreven worden naar het distale deel van de mergholte. Een bezwar hierbij is, dat het metaal van de boor vaak een andere samenstelling heeft dan het metal van de pen, zodat gevar voor corrosie ontstat.

ook voor excentrisch uitboxen van de mergholte mot gewakt worden. Dit gebeurt vooral aan de voorzijde van het femur ten gevolge van de antecurvatie. Het opbaren dient te geschieden over de hele lengte van de schacht. Stabiliteit wordt alleen berelkt indien de boor boven en onder het niveau van de fractur over een afstand van 3 a 4 cm goed "pakt". Indien hier niet op gelet wordt, wordt geen stabllitelt bereilt volgens het Kuntscherprincipe. Indien weerstand wordt ontmoet 1 s het van belang het opborengeleidelijk en zonder veel kracht voort te zetten. Het 1 s an te raden on bif het toenemen van de weerstand tijdens het boren, de boor terug te trekken daar deze geheel gevuld kan zijn met boomeel. Dit kan door warmte-ontwikkeling tot breuk van het boomaterial aanleiding geven, terwill door de hitte ook necrose van het bot ontstaat (Kintscher 1967, Schatzker $1980)$.

\section{Het inslaan van de pen.}

Nadat de juiste lengte is gemeten, controleert de operateur zelf de maten. Naast een juiste dilameter moet ook een juiste lengte gekozen worden. Eer te korte mergpen kan, zeker bij een laag in de potentféle isthmus gelegen. fractuur, tot instabiliteit leiden. Een te lange pen zal ultsteken boven de trochanter en de abductie beperken of zal in het kniegewricht bimendringen. Dencker (1964) heeft drie gevallen $(0,66 \%$ ) wan perforatie van het knlegewricht bij intramedullatre osteosynthese beschreven. Het inslaan van 
Plgurer 21.

\section{PROBLEMEN BY DE OPERATIE}
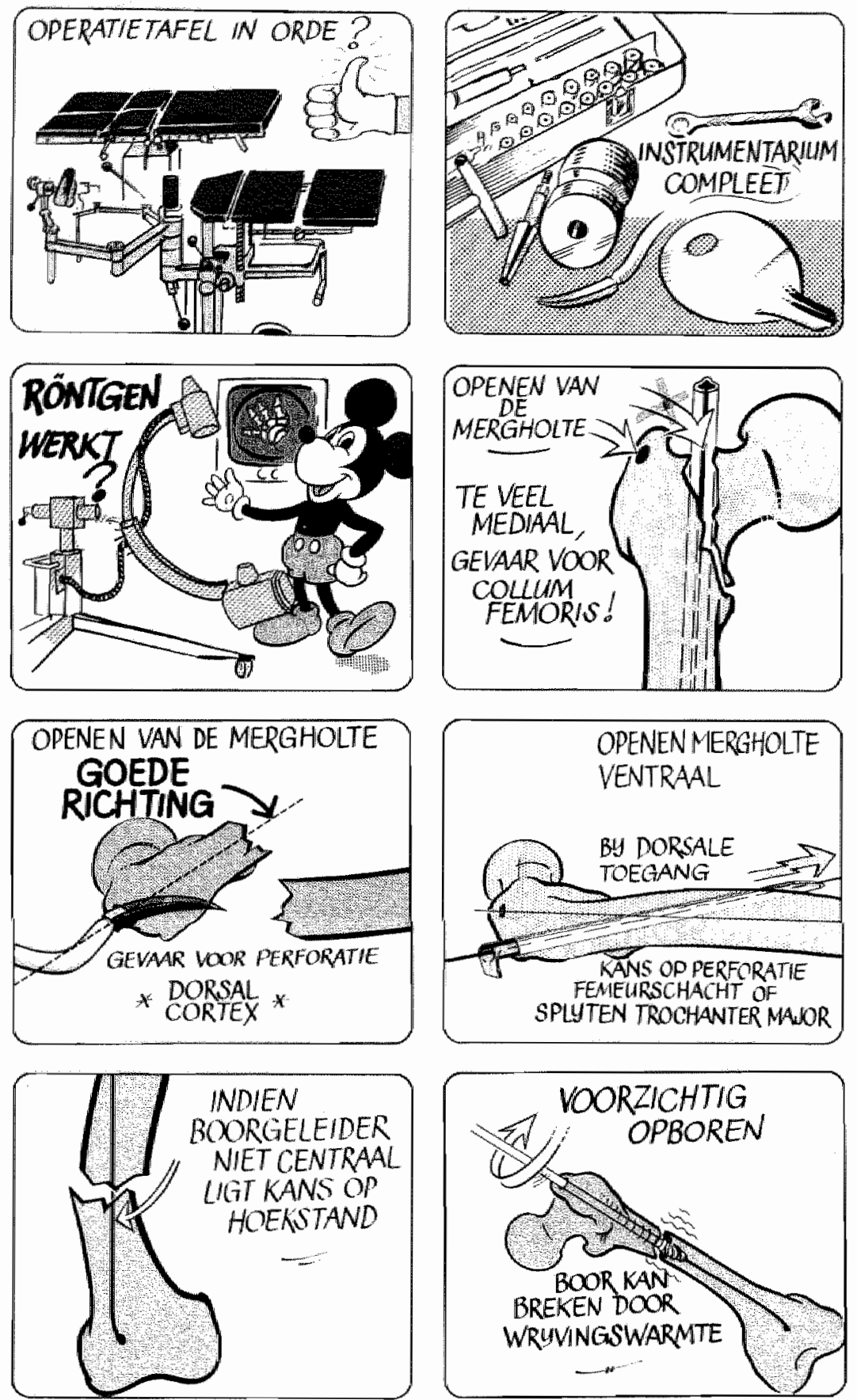

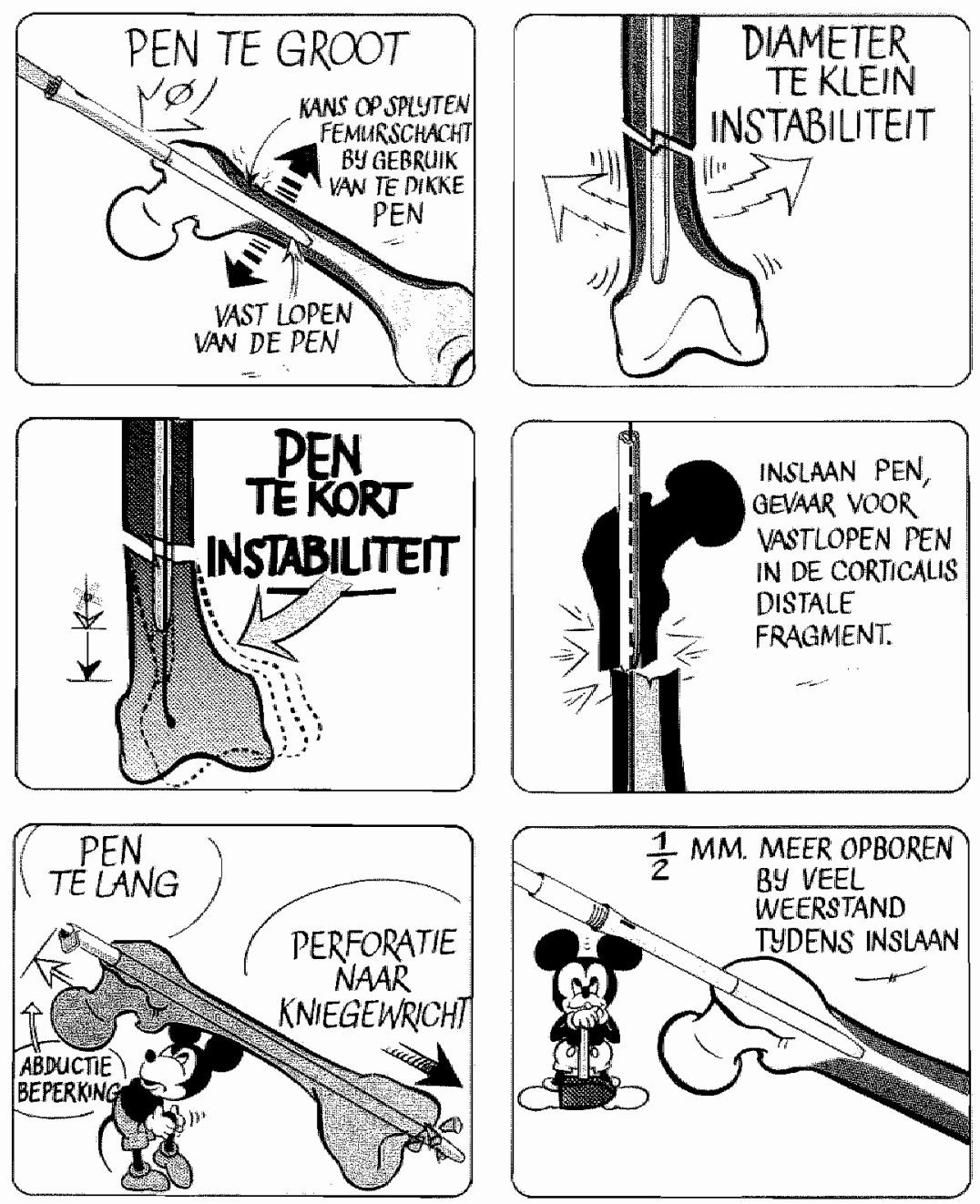

VOORKOM ROTATIE VOOR HET INSLAAN VAN DE PEN LABIUM LATERALE OP LABIUM LATERALE.
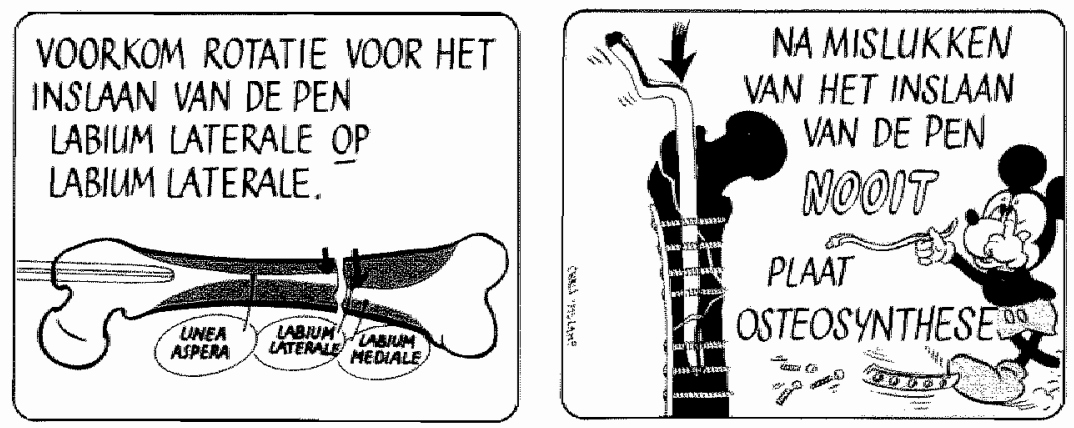
de pen geschedt ower een pengelelder wet een diameter van 4 m zonder knop aan het ulteinde. Deze minder bulgzame pengelelider behoedt voor een gevreesde complicatie waarbif de pen tijdens het inslaan als een holle beltel de corticalls binnendringt en het femur kan doen splijten. Dencker (1964) beschrlfft deze complicatie in zes $(1,3 \%)$ van de 459 gevallen. In onze gerle is dit tweemad voorgekomen (patiënt 003 en 121). Het inslaan mag noolt met kracht gebeuren. Indien veel weerstand wordt ontmoet, zal een halve mllitmeter verder opgeboord moeten worden. Het is nooit geheel te voorspellen of een mergpen al dan niet vast zal lopen, omdat er namt de inklemilng in de mergholte door de fyslologische antecurvatie van het femur ook wrijving tussen de pen en het femur ontstaat. Bovendien zullen er door het drijuen van een recht lichaam in een gebogen kanaal rotatiemomenten ontstaan (Lemmens 1981). Vastlopen van de pen wordt door Dencker (1964) in 24 gevallen $(5,2 \%)$ beschreven. In 12 gevallen kon de pen teruggetrokken worden, in de overige gevallen werd de pen ter hoogte van de trochanter afgezaagd. Bij de in Maastricht behandelde patienten werd deze complicatie bij het inbrengen noolt gezien. Indien een mergpen onwrikbaar in de mergholte vastloopt kan, ten elnde deze te verwijderen, het femur thet de osclilerende zaag il de lengterichting opengezaagd worden (Broad 1977, Koslowsk1 1962, Schatzker 1980). Ook kan men de mergpen boven de top van de trochanter afzagen en verder een conservatieve therapie kiezen (Dencker 1964). Indien de pen boven het niveau van de fractuur is vastgeLopen kan deze met een klefnere mat pen vanult de fractuur terug geslagen worden (Lottes 1953).

On bij het inslaan rotatie-afwljkingen the voorkomen dient, voordat de fractuur met de pen gepasseerd wordt, de repositie wat betreft rotatie gecontroleerd te worden. Bi $j$ het passeren van de fractuur moet de punt van de pen röntgenologisch gevolgd worden om te vermijden, dat de pen in de corticalis van het distale fragment gedreven wordt. Indien dit gebeurt moet de pen teruggeslagen worden en na uitwendige manipulatie een nieuwe poging worden gedaan. De pen wordt vervolgens, onder controle van de rotatie, in het femur geslagen tot het proximale deel van de pen op gelijk hoogte is met de top van de trochanter major. Goede contrôle van lengte en diameter van de pen voorkomt, bij voorzichtig insiaan ervan, het overlangs splijten van de femurschacht of het uitbreken van grote fragmenten. In een dergelijk geval kan met het Kaessmann/cerclage-systeem, de grendelpen en fixateur externe alsnog stabilitelt worden bereikt. Nooit mag aansluitend aan een mislukte poging tot intramedullaire osteosynthese, waarbij de mergholte 1 s opgeboord, worden overgegan tot osteosynthese met een plat, daar dan zowel de medullaire als periostale vatuoorziening vernield wordt. In zeldzame gevallen komt het voor, dat de pen bulten de mergholte komt te 11.ggen van het distale fragment. Het is mogelijk, dat een dergelifke complicatie bij röntgencontrole in éfn richting niet onmiddellijk wordt opgemerkt. Dencker (1964) heeft dit in twee gevalien $(0,44 \%)$ gezlen. Daarnaast beschrifft Dencker in twee gevalien $(0,44 \%)$ een perforatie van de femurschacht. Verder vindt men in de literatuur een melding over een luchtembolie ten gevolge van het inslaan van een Kintscherpen (Lécutier 1957). Küntscher (1967) waarschuwt tegen te snel inslaan van een Kintscherpen aangezien hierdoor mogelijk vetembolleën kunnen ontstaan. Bilj symptomen die kunnen passen bij een vetembolle mag geen intramedullaire osteosynthese worden uttgevoerd. Kïtscher wacht daarom een aantal dagen alvorens tot het inbrengen van een mergpen over te gaan. Zeer uitzonder$11 \mathrm{Jk} 1 \mathrm{~s}$ de conplicatie waarblj tijdens een gesloten procedure de pen achter het distale fragment van het femur is geslagen, en door een beschadiglng van de arterla femoralis een amputatie moest worden verricht

(Watson-Jones 1950). 


\subsection{NABEHANDELING}

Bij de nabehandeling van patiënten warbif een femurschachtfractuw ls gestabiliseerd met een mergpen treden over het algemeen welnig problemen op. Postoperatief worden de patiënten de eerste dagen verpleegd met heup en knie in $90^{\circ}$ flexie, om in een later stadlum er van verzekerd te $\mathrm{zljn}$ dat de flexlemogelijkheid wan de knie tot $90^{\circ}$ behouden bliju (Schatzker 1.980). In een vroeg stadium moeten isometrische quadricepsoefeningen en actieve oefeningen van het been verricht worden. Dit vroegtijdig oefenen zal bij mobilisatie, partiëel en volledig belast lopen, de stabilitelt van het been ten goede komen. Veel aandacht moet besteed worden aan het voorkonen van druk op de nervus peroneus.

In principe kan de patiẻnt gemoblliseerd worden nadat blijkt dat de wondgeneztng ongestoord is. Bij asteosynthese met een küntscherpen kan na 2 tot 4 weken het been volledig belast worden. Bij osteosymthese met een Kaessmannpen, al of niet in combinatie met cerclage, wordt volledig belast lopen toegestaan op geleide van de radiologische bevindingen (hoofdstuk 7.2.10., 8.3.).

Indien de osteosynthese niet geleid heeft tot goede rotatiestabiliteit moet de nabehandeling worden aangepast. Het onderbeen van een in bed liggende patiënt heeft een tendens on in exorotatie te gaan liggen (Schatzker 1980). Deze rotatie kan worden tegengegaan door het been op een Braunse slede te leggen. Dok kan gebrulk worden gemaakt wan een WatsonJones-laars, waarbif oefenen van knie en heupgewricht mogelijk bilfft. Zodra op de röntgenfoto enige callusvorming zlchtbaar is, kan een begin worden gemaakt met partiëel belast lopen. Indien de periostale callusvorming toeneemt, kan worden uitgebreid naar volledig belast lopen.

Indlen volledig belasten van het been mogelijk is, blifkt er ondanks isometrische quadricepsoefeningen valk toch nog een zekere atrofie van de bovenbeensmusculatuur te zijn opgetreden.

Het is in verband met het herstel van deze atrofle zeer belangrijk veel aandacht te besteden aan het loop- en standpatroon. De laatste faren wordt hiervoor in Mastricht een uitvoerige loopinstructle gegeven om de patiënten aan te zetten hun been snel en verantwoord te belasten. Deze looplnstructle beoogt het herstel van een normal looppatroon waarbif gelet wordt op een evenwichtige staplengte, het afrollen van de voet en de coördinatie van de heup-, knie- en voetbeweglag. De ervaring met deze looplinstructie 1 opgedaan bif de toepassing van bandagetechnieken bil de behandeling van enkelbandletsels (Van den Hoogenband 1982).

Wat betreft de sportbeoefentng, wordt onderscheld gemakt tussen sporten waarbij butten wedstrijdverband gecontroleerde bewegingen worden gemaakt ( 0. . lopen, fletsen, fitnesstralning) en wedstrijdsporten (o.a. voetbal, hockey, tennis, atletiek). De sportbeoefening warblj gecontroleerd wordt bewogen, kan toegestaan worden vanaf het monent warop volledig belast wordt. Wedstrijd- en contactsport worden toegestaan indien er röntgenologisch volledige consolldatie is en er een volledig normal looppatroon, tot hardlopen toe, is ontstaan.

Meestal kan het osteosynthese materlaal na én jaar verwijderd warden. Refracturen na verwijderen van het materiaal zoals deze bij platosteosynthese worden waargenomen zijn nlet opgetreden (Roberts 1977). P1jnklachten door callusvorming rond de trochanter major zijn soms een reden om de pen nog binnen het jaar te verwijderen. 



\section{Behandelingsprotocol voor femurschachtfracturen}

In de voorafgaande hoofdstukken zijn de behandelingsresultaten en problemen bij 139 patiênten met 143 Eemurschachtfracturen besproken. Met de Kuintschemethode, aangevuld met de mogelijkheden van de kaessmamcompressiepen, kunnen alle wookomende fracturen van de fenurschacht oefenstablel worden geopereerd. De Küntschemethode heeft als nadeel een geringe rotatiestabiliteit en een toepassingsgebied, dat beperkt is tot het gebled van de potentiële isthnus bij dwarse en korte schuine fracturen.

De Kaessmannpen heeft als nadeel een ingewikkelde operatietechniak. Toch is in vergelijking met een plaatosteosynthese het aantal gestoorde consolidaties en infecties laag (Winquist 1980). De resultaten behald met Küntscher- en Kaessmannpen in combinatie met cerclage zijn, vergeleken met de in de literatur beschreven behandelingsresultaten van de A. O.-plat bij cominutieve femurschachtfracturen weergegeven in tabel 57.

Tabel 57.

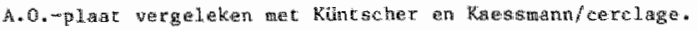

\begin{tabular}{|c|c|c|c|c|}
\hline atueur & faar & $\begin{array}{l}\text { aantal } \\
\text { fracturen }\end{array}$ & tofecte & $\begin{array}{l}\text { gestoorde } \\
\text { consolidatie }\end{array}$ \\
\hline knotstra & 1973 & 43 & 7 帮 & $13,5 \%$ \\
\hline Taillard & 1976 & 80 & $4 x$ & $5 \%$ \\
\hline Koud 1 & 1977 & 100 & $6 \%$ & $6 \%$ \\
\hline Roberes & 1977 & 35 & $2,8 \%$ & $11,4 \%$ \\
\hline Tschet ne & 1977 & 160 & $8,6.6$ & $13,1.4$ \\
\hline Stapert & 1979 & 34 & 2,28 & 8,8 \\
\hline
\end{tabular}

De 34 in Mastricht via de intramedullaire methode behandelde fracturen zijn verzameld in de periode van 1967 tot 1979 . Ofschoon de getallen klein zijn, is het duidelijk dat de stablele intramedullajre asteosynthese zeker niet onder doet voor andere behandeling smethoden (Stapert 1979).

De nadelen van de plaatosteosynthese zijn de devascularisatie van het bot en de spier bij repositie en het aanbrengen van de plaat. Het been kan bovendien na plaatosteosynthese langdurig niet belast worden (Schatzker. 1980). Na verwijderen van het osteosynthese matertal dreigt bovendien de refractunr.

De behandelingsresultaten van de beschreven osteosynthese vomen ziju de reden geweest, dat er in de laatste faren gezocht is naar verbeterde intramedullaire osteosynthese technieken.

over de warde van deze nieuwe technieken kan an de hand van de beschreven patiëntenserie natuurlijk geen wetenschappelijk gefunderd oordeel worden gegeven.

In de laatste twee jaar zljn in onze kliniek een 30-tal patfënten behan deld met de grendelpen en een tiental patienten met de verbeterde compressiepen volgens Derweduwen. Deze twee laatste intrameduldalre osteosynthese technieken hebben door de vereenvoudiging van de operatietechniek en een verbeterde rotatiestabiliteit een plates gekregen in het behandelingspratocol.

In de volgende paragrafen worden de overteglngen besproken, die van belang zijn bij de keuze van een behandelingsmethode. 
1. Leetetid.

BH n net gesloten eplfysairlijnen wordt, indien er geen sprake is van multitrama, gekozen voor de conservatieve behandeling (Bjerkreim 1983). ook bif adolescenten zal conservatieve theraple overwogen worden. op gevorderde Leeft1jd, warblj de grens blj ongeveer 65 jaar kan liggen, mot gekozen worden voor een operatieve therapie zonder langdurige intinoblifiatie.

2. Pre-exitente ziekten.

Pre-existente zlekter verhogen het rislco van een operatie, maar bovenal van langdurlge immobllisatie. Het is soms verwonderlijk hoe de fracturen van patienten met ermstige algemene problemen toch zeer goed consolideren. Zo is bijvoorbeeld hemodialyse of behandeling met cytostatica geen contraindluatie woor operatie.

3. Algemene toestand ten gevolge van het ongeval.

Multitramapatiënten zijn patiënten met letsels van twee of meer belangrijke orgaanstelsels. Hun I.S.S. ligt daarbij meestal boven de 20 punten. Stablele operatieve fixatie van met name de femurschachtfracturen maak de patient verpleegbaar en draagt aanzienlijk bij an de preventie van infectie, "resplratory distress"-syndroom, sepsis en "multiple organ failure" (Gortis 1982).

\subsection{WEKE DELEN LEETEL}

Een fractuur wan het bot betekent altijd een niet te verwaarlozen letsel wan de buiten het bot gelegen structuren in het bovenbeen. De weke delen koker wordt bij een direct trauma door geweldsinwerking wan buiten af beschadigd nog voor het bot breekt. Er treden bovendien belangrifke letsels op, doordat een dynanisch belast femur binmen de weke delen koker bij de fractuur als het ware explodeert (Sauter 1983). Aangezien het bot voor zijn herstel in de eerste weken na de fractuur wijwel geheel afhankelijk is van de vascularisatle vanult de weke delen, bepaalt de toestand van de weke delen in eerste instantle de prognose van de fractuur. Waar in een. gezonde weke delen koker een fractuur ook zonder absolute stabiliteit voortreffelijk zal genezen, betekent stablele fixatie van het bot bij een. ernstig weke delen letsel vak de enige mogelifkheld het been te behouden. Ermetg letsel van de weke delen betekent, dat er absoluut tot osteosynthese of flxateur externe moet worden overgegan. Dit geldt ook bij kinderen.

10.2.1. Fuld letsel

Errstig verlies of letsel van de huid door contusie, laceratie, décollement of verbrand 1 ng wormen een 1 ndicatie voor acute osteosynthese of fixateur externe.

10.2 .2 . Wathetse1

De prognose van een bimnen zes uur na het ongeval operatief behandeld letsej. van bloedvaten wordt in hoge mate bepald door het tevens primalr uitwoeren van een goede osteosynthese.

10.2.3. Zenuwletse1

Bij zenuwletsels is osteostynthese aangewezen. Indien een zenuwletsel is vastgesteld, zal dit zo mogelijk binnen zes uur behandeld worden met een primaire anastomose of door interpositie van een zenuwtransplantaat met 
behulp wan micrachirurgische technieken. Het ls mogelijk beter een proximal in het bovenbeen gelégen fractuur met tramatische onderbreking van de nervus ischiadicus en ernstig weke delen letsel door middel van een primaire amputatie te behandelen.

\subsubsection{Spierletsel}

Moelijk te beoordelen is het spierletsel. Vitale spler bloedt, contraheert en is rood van kleur. Indien aanwijzingen woor ernstig spierletsel of compartimentsyndroom bestaan, betekent stabiele osteosynthese met fasciotonieën vaak de enige kans op behoud van het been.

\subsection{LETSEL VAN HET BOT}

10.3.1. Plaats van de fractuur in de femurschacht

Zoals in hoofdstuk 5.1. is uiteengezet wordt de ard van de osteosynthese bepald door de relatie tussen de potentiêle isthus en de plaats van de fractur in de fenurschacht. Niet comminutleve dwarse en korte schuine fracturen kunnen in het gebied van de potentiele isthmus voortreffelijk behandeld worden met een Küntscherpen. Bulten de potentlële isthmus moet gekozen worden tussen een compressiepen en een grendelpen (Eiguur 22 ).

10.3.2. Vorm van de fractuur

Dwarse en korte schuine fracturen kunnen goed met de kintscherpen, buitem de potentiële isthmus met de grendelpen worden behandeld. Bij spiraalfracturen zal het aambrengen van cerclagedraden en axiale compressie noodza-kelijk zijn.

Bij comminutieve fracturen kan men kiezen tussen een grendelpen of een fixateur externe die beiden volgens hetzelfde principe werkzam zijn. De botlengte en rotatie van het femur worden hersteld zonder op nauwkeurige anatomische repositie van het ertussen gelegen deel acht te slaan (figuur 22).

\subsection{BEGELEIDENDE LETSELS}

Na herstel van respiratie en circulatie bij een multitraumatiënt moeten grote schachtfracturen gestabiliseerd worden. Hono- af heterolaterale begeleidende letsels die, indien $z i j$ niet gestabiliseerd worden het oefenen en belasten beinvloeden, bepalen mede de indicatie tot asteosynthese. Hetzelfde geldt voor de aanwezigheid van wonden in het gebled wan de fractur of elders (Riska 1977, Goris 1982, Al1göwer 1983, Tscherne 1983).

\subsection{CONCLUS RE}

Deze studie is verricht in een perfode warin de behandeling van femurschachtfracturen duidelijk in beweging ls. Over het algemeen z1jn goeda functionele resultaten berelkt hoewel de behandeling in vele gevallen negatief is beinvloed door frequent optredende, inder in het oog springende complicaties en anatomische restafwjlkingen. Slechts $27 \%$ van de patiënten herstelt geheel klachtenvilj zonder restverschilnselen of complicaties doorgemaakt te hebben. Een fenurschachtfractuur blijft ondanks de velle technieken die voor de behandeling ervan worden angewend, een moeliljk te behandelen fractuur.

In onze kliniek hebben in de latste decennia patienten met een femurschachtfractuur, die door vorm of locallsatle onder andere omstandigheden met platosteosynthese behandeld zouden zijn, een intramedullalre osteosynthese ondergaan.

De beste methode van osteosynthese is die operatietechniek, die zoveel mogelijk aangepast is aan de omstandigheden van een bepaalde patient en gekozen wordt uit het arsenaal van goede mogelljkheden waamee een be- 
paslde chlrurg vertrouwd is. Voor Mastricht betekent dit de intramedullatre osteosynthese. Door de grote hoeveelheld van factoren die de keuze van osteosynthese van een femurschachtfractur bij een patiënt bepalen, is het duidelijk, dat het propageren van éen enkele methode niet mogelijk is. slechts een eventichtige keuze uit de verschillende nogelijkheden zal tot betere realtaten kumen leiden.

De bestudering van met Kütscher- en Kaessmanncompressiepen behandelde patiënten heeft laten zien, dat met intramedullaire nethoden moeilijke fenurschachtfracturen te behandelen zifn. Ondanks de beschadiging van de intramedullatre vatuoorziening, kunnen in comblnatie met cerclage comminutleve en splralfracturen intranedullair behandeld worden. Spiraalfracturen van de femurshacht bif oudere patiënten kunnen met compressie en cerclage zeer stablel gefixeerd worden. De Kaessmannpen moet gezien worden als voorloper wan de meer recent ontwikelde compressiepen volgens Derweduwer (1979). Met de komst van de grendelpen ontwikkeld door Klemm (1972) en vervolmakkt door Grosse en Kempf (1978) en sinds bijna twee jaar beschlkbaar in Nederland, is een methode van intramedullaire osteosynthese operationee1 die vrljwel alle nadelen van küntscher- en Kaessmannpen mist. Het is gezlen de zeer redelijke behandelingsresultaten van de met Kintscherpen en Kaessmann/cerclage behandelde patiënten onredelijk het systeem van de grendelpen op dit moment niet aan te prijzen. Daarom heeft deze nleuwe methode warmee alle femurschachtfracturen kunnen worden behandeld eer plaats heeft gekregen in ons behandelingsprotocol. Superieur bij de behandeling van dwarse en korte schuine fracturen in het gebied van de potentiêle Lsthmus blijft de Küntscherpen.

Figuir 22. Behandelingsprotocol.

Schema toepassing verschillende osteosynthesevormen, afhankelijk van leefthid, algemene toestand weke delen, vorm en plaats van de fractuur.

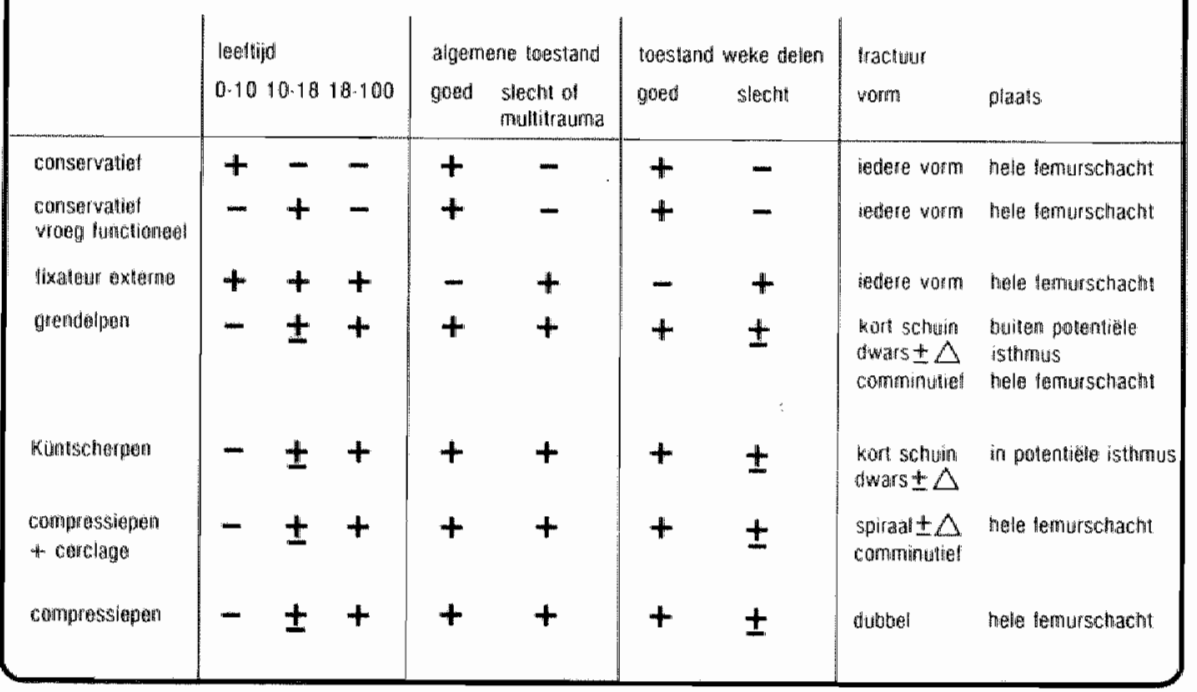


Fracturen die aan deze criteria voldoen, onvatter slechts $50 \%$ van het totale aabod van femurschachtfracturen. De overige $50 \%$ wijn met de intramedullaire grendelpen en verbeterde compressiepen volgens Derweduwen, thans ook geschikt voor intramedullaire fixatie.

Indien de behandeling van femurschachtfracturen met een mergen tot de routine van een bepalde klinlek behoort, kan ledere femurschachtfractur na een keuze uit Küntscher-, grendelpen of compressiepen, gestabiliseerd worden.

Het beschrijwen van serles patiënten behandeld volgens én bepalde methode is daarom niet zinwol.

Het is noodzakelijk on prospectief onderzoek te verrichten nar de behandelingsresultaten van een bepalde fractuur, warbif de keuze uit de verschillende therapeutische mogelijkheden gemaakt wordt via een van tevoren opgesteld protocol. Alle patiënten net ển bepalde fractur zullen hierbij beschreven moeten worden. Door gebruik te maken van een scoringssysteem voor begeleidende letsels, kan daarblj rekening worden gehouden met de ernst van het trauma. Patiënten kunnen hiermee in verschillende categorieën van ernst ingedeeld worden. Houden wij naast de bekende küntschermethode rekening met de nleuwe technische mogelijkheden van de fixateur externe en van de interne fixatie middels grendelpen en compresslepen, dan kan onderstaand behandelingsschema worden alangehouden (figuur 22).

Prospectieve toepassing van het behandelingsprotocol zal in de toekomst na onderzoek van de resultaten pas tot wetenschappelljk verantwoorde conclusies leiden. 



\section{Samenvatting}

Deze studie heeft als doel de warde an te geven van de intramedulladre osteosynthese bij de behandeling van femurschachtracturen. Een zorgvuldige analyse van de indicatiestelling en behandelingsresultaten van 139 behandelde patiënten raet 143 femurschachtfracturen, in een periode van tien jaar, heeft geleld tot protacollair geneeskundige aanbevelingen voor de behandeling van patienten met een femurschachtfractur.

In hoofdstuk 2 wordt een overzicht gegeven van de historie van de opertileve en niet operatleve behandeling van femurschachtixacturen.

In hoofdstuk 3 wordt de anatomie van het bovenbeen besproken. De fiemurschacht wordt gedefiniëerd als dat deel van het femur, dat gelegen is tussen de onderbegrenzing van de trochanter minor en een 11 jn getrokken loodrecht op de lengte-as van het femur, $6 \mathrm{~cm}$ boven het knlegewricht.

In hoofdstuk 4 wordt ingegaan op de verschillende theorleën over botaanmaak. De invloed van opboren van de mergholte, het aanbrengen wan cerclagedraden en de mechanische stabilitelt op de botaanmaak worden besproken. Een toelichting wordt gegeven op de wijze wasrop blj gebrutk van de küntscherpen, de Kaessmannpen en de Kaessmampen in combinatle met cerclage, mechanische stabiliteit wordt bereikt.

In hoofdstuk 5 wordt de indicatiestelling tot, de techniek van de drie typen intramedullalte osteosynthese, evenals de nabehandeling beschreven. De indicatlestelling wordt gesystematiseerd door invoering van het begrip potentlële isthmus. De potentiële isthmus is dat deel van de femurschacht, waar na opboren van de nergholte voldoende stevig cortlcaal bot overblijft on met elastische inklemming van een Küntscherpen stabiliteit te krljgen. Alleen bij dwarse en korte schulne fracturen in deze potentiele isthmus, is met een Kintscherpen voldoende stabiliteit te verkrijgen. Fracturen dile niet aan deze voorwaarden voldoen, moeten met een andere operatietechniek behandeld worden. In Mastricht worden hiervoor de Kaessmannpen en de Kaessmannpen in combinatie met cerclage gebruikt.

Het tijdstip van de operatie 1 s afhankelifk van de begeleidende letsels en de toestand van de weke delen. Multitraumapatiënten en patlënten met een errstig weke delen letsel worden acuut geopereerd. On de vascularisatle van het gefractureerde bot te laten herstellen, worden patienten met gesloten geisoleerde letsels in principe na tien dagen geopereerd.

In hoofdstuk 6 worden begeleidende letsels ingedeeld, warb»l gebruk wordt gemaakt van de Injury severtty Score (I.S.S.). Gebruik makend van deze I.S.S. kunnen patiënten afhankel1jk wan de ermst van het trauma, in categorieën worden ingedeeld. Van de bestudeerde patiënten heeft $27 \%$ als enig letsel een femurschachtfractur.

In hoofdstuk 7 wordt een analyse gegeven van het patientenbestand. De gew middelde leeftijd van 101 mannen en 38 vrowwen bedraagt 33,5 jaar. B1j $7,9 \%$ van de patiënten komen pre-exilstente zlekten voor. Een verkeersongeval is $\mathbb{1}$. $81 \%$ van de gevallen de oorzaak van de femurschachtfractuur. Het interval tussen ongeval en na-onderzoek bedraagt gemiddeld 6,5 jaar. Met een Küntscherpen zijn 80 fracturen, 32 fracturen met een Kaessmannpen en 31 fracturen met Kaessmamnen en cerclage behandeld. De opnameduur bedraagt gemiddeld 63 dagen. De tijdsdur tot róntgenologische consolldatie bedraagt woor de küntschergroep 14,9 weken, voor de Kaesimanngroep 19,6 
weken en voor de Kaesmann/cerclage groep 13,1 weken (tabel 22 ).

Ernstige complicaties zoals infectle, gestoorde consolidatie en ernstig. verles van functie komen alechts blj $7 \%$ van de patienten voor. Toch maakt het merendeel van de patienten (73\%) minder belangrijke complicaties door of houdt gerlnge klachten (tabel 44 ).

SIechtg: $27 \%$ van de patienten heeft het genezingsproces van een femurschachteractuur doorgemaakt zonder complicaties of blijvende klachten. Bij de anatomische afwi jkingen vormt de rotatiedeformiteit, die bij $47 \%$ van de patlënten wordt gevonden, het grootste probleem.

In hoofdstuk 8 wordt een overzicht gegeven van de behandelingsresultaten van 25 patienten die niet operatief zijn behandeld. 14 Patiënten zijn conservatief behandeld met draadextensie op Braunse slede, elf patienten zifn vroeg functloneel behandeld met Perkinstractie en "thigh lacer" De opnemeduur bedraagt voor de conservatief behandelde patienten gemiddeld 87 dagen, voor de met Perkinstractle behandelde patienten 56 dagen. Gemiddeld verlopen 18,7 weken tot röntgenologische consolidatie in de conservatief behandelde groep en 13,4 weken bij de met Perkinstractie behandelae patiënten (tabel 47).

BH.j de complicaties van de niet operatief behandelde patiënten wordt Een patiënt gezien met een diepe infectie, terwijl in het totaal vier patiënten een refractuur hebben opgelopen. Een corrigerende asteotomie was achteraf noodzakelijk bij twee patlënten wit de conservatief behandelde groep en bij Een patiënt uit de met Perkinstractie behandelde groep (tabel 53).

In hoofdstuk 9 worden de voor- en nadelen van de toegepaste behandelingsmathoden van patiënten met femurschachtfracturen, besproken. Een toelichting wordt gegeven over het woorkomen wan problemen met begeleidende letsels, pre-existente ziekten, indlcatiestelling, pre-operatieve voorberelding, operatietechniek en nabehandeling.

In hoofdistuk 10 wordt voorultiopend op prospectlef onderzoek een werantwoording afgelegd voor de opstelling van een behandelingsprotocol, dat voor dit doel gehanteerd zal worden (figuur 22). 


\section{Summary}

The idea behind this study was to assess the value of intramedulary osteosynthesis in the treatment of femoral shaft fractures.

A careful analysis of the indications for osteosynthesis and the results of the treatment of 139 patients with 143 fractures, within a perlod of ten years, led to formal medical recommendations for the treatment of patients with fractures of the femoral shaft.

In chapter 2, a brief review is given of the history of operative and non-operative treatment of the femoral shaft fracture.

In chapter 3, the anatomy of the femur is discussed. The femoral shaft is defined as the segment of the femur which is situated between the lower limitation of the trochanter minor and a line ruled perpendicular on the longitude axts, 6 cms above the knee-joint.

In chapter 4, different theorles of bone formation are discussed. The influence of reaming of the medullary cavity, the use of encircling wire loops for the fixation of bone fragments and of mechanical stabillty on new bone formation is discussed.

The way in which mechamical stablilty is achieved by using the kintschernail, the Kaessmannatl and the Kaessmannali in combination with enciocling wire loops is explained.

In chapter 5, the indications for operation, the technique of the three types of intramedullary osteosynthesis, as well as the follow-up treatment are described. The choice of method for intranedullary fixation is deftned by adding the concept "potential isthmus".

The potential isthnus is defined as the segment of the femoral shaft where, after reaming of the medullary cavity, sufficlent strong cortical bone remains to achieve stability by elastlic impingenent of a kintschernall. Only in transverse or short oblique fractures located in this potential isthmus, sufficient stability is achleved with a kintschernail. For fractures not within the limit of the potential isthmus, a different method of osteosynthesis has to be used. In these cases the Kaessmannall and the Kaessmannnail in combination with encircling wire loops are used in Mastricht.

The moment of operation 1 s dependent on the associated tingurles and the soft tissue damage.

Mult-trama patients and patients with serlous soft tissue damage are operated upon acutely. In patients with isolated injurtes the osteosynthesis is delayed for ten days.

In chapter 6, the assoclated injurles are described with the use of the Injury Severtty Score (I.S.S.). In 27 percent of the patients, the femoral shaft fracture is their only injury.

In chapter 7, an analysis is given of the patients examined. The average age is 33.5 years. 38 Women and 101 men are described. In 7.9 percent of the patients, pre-existing diseases exist. In 81 percent of the cases, a traffic acclident is the cauce of the femoral shaft fracture.

The average interval between accldent and the examination for follow-up amounts to 6.5 years.

80 Fractures were stabilized by means of a Kütschernall, 32 fractures by means of a Kaessmannnat1, and 31 fractures were operated by means of a 
Kaes smannall in comblnation with encircling wire loops.

The average duration of hosptalization amouted to 63 days. The duration int1 rad lologlcal unton was 14.9 weeks for Kintscher patients, 19.6 weeks fox Kaesmann patients and 13. I weeks for patients with Kaessuann and enclreling wre loops (table 22 ).

Sayere conplications stich as infections, delayed union and severe loss of function, were present in 7 percent of the patients *

Minor complications and complaints related to the treatment of the femoral fracture appeared howewer in 73 percent of the patlents (table 44).

Only 27 percent of the patients with a fracture of the femoral shaft, went through the process of fracture healing without complications or persisting complaints.

In case of anatomical deformities, the rotational deformity seems to be the maln problem, as found in 47 percent of the patients.

In chapter 3 , a review is presented of the results of the non-operative treatment of 25 patients. 14 Patients were treated conservatively with tiblal akeletal traction on a Brauns" frame. Eleven patients had early functional treatment wh Perkins tracton and thigh lacer. The average duration of hospitalization amounted to 87 days for patients who were conservatively treated and to 56 days for patients treated with Perkins traction. The duration until radiological union is on an average 18.7 weeks for conservatlve treatment and 13.4 weeks for early functional creatment whth Perkins traction and thigh lacer (table 47).

Deep infection occurred in one conservatively treated patient. Two patients in both groups had a refracture. Osteotomy for correction of angular or rotational deformity was necessary for two patients in the conservative group and one patient in the Perkins group (table 53).

In chapter 9, problems accuring in the process of diagnosis and treatment of patients with femoral shaft fractures, are discussed. An explanation regarding problems with assoclated injurles, pre-existing diseases, indications for osteosynthesis, pre-operative preparation, operation-technique and follow-up treatment is presented.

In chapter 10, a justification is made to the treatment protocol. The development of this protocol for the treatment af patients with a fracture of the femoral shaft, 1 ment to be the basis for a prospective clinical trial in the future (figure 22). 


\section{Literatuur}

Allen, W.; Heiple, K. Burstein, A. (1978):

A fluted femoral intramedullary rod.

I Bone Joint Surg, vol. 60A, 4: 506.

Allgöwer, M.; Müller, M.; Schenk, R. ; Willenegger, H. (1963):

1. Biomechanische Prinzipien bel der Metallverwendung am Knochen.

Langenbecks Arch Chir: 305.

All 1göwer, M.; Border, J. (1983):

Management of open fractures in the multiple trauna patient.

World J Surg, 7: 88 .

Arnesen, A. (1951):

Encircling suture (cerclage) in oblique fractures.

Acta Chir Scand, 102: 20.

Atkinson, P.; Weathere11, J. (1967):

Varlation in the density of the femoral diaphysis with age.

J Bone Joint Surg, vol. 49B, 4: 781 .

Baker, S.; $0^{\prime} \mathrm{Ne} 111$, B.; Haddin, W.; Long, W. (1974):

The infury severity score, a method for describing patiënts with multipele injuries and evaluating emergency care.

J Trauma, vol. 14, 3*187.

Bassett, C. (1962):

Current concepts of bone formation.

$J$ Bone Joint Surg, vol. 44A, 6: 1217 .

Binnendijk, B.; Ponsen, R. (1969):

Behandeling van femurschachtfracturen door middel van plaatfixatie.

Ned. Ver. tot bevordering van de Cnirurgische Wetenschappen, 2 le congres.

Bjerkreim, I.; Langard, $0 .(1983)$ :

Effect upon longitudinal growth of femur by intramedullary nailing in rats.

Acta Oxthop Scand, 54: 363.

Böhler, L. (1945):

Technik der Knochenbruchbehandlung $\operatorname{lm}$ Frleden und Im Krlege.

Ed.: W. Maudrich Verlag, Wenen.

Böh1er, L. (1949):

Küntscher" s medullary nalling.

J Bone Joint Surg, vol. 31A, 2: 295.

Böhler, L. ( 1957$)$ :

The treatment of fractures.

Ed.: Grime \& Stratton, New York, wol. 1, 2 en 3. 
Broad, C.; Percy, A. (1977):

The jammed Kuntscher nail:-a method of releasing the nail and report of a case *

Injury, vol. 9, 2: 135 .

Brooker, M. (1961):

A new concept of capillary circulation in bone cortex - some clinical applications.

Lancet, 1: 1078 .

BuL1, J. (1975):

Severity score of road traffic casualties in relation to mortality, time of death, hospltal treatment time and disability.

Accild Anal Prev $3,7: 249$.

Bul1, J. (1982):

Injury severtty scoring systems.

Injury, vol. 14, 1:2.

Burxi, C.; Kreuzer, U.; Limmer, J. (1982):

Principles and practice of fracture treatment in the multiply injured patient.

Injury, vol. 14, 1: 44 .

Carr, C.; Miller, M.; Charlotte, N. (1958):

Management of difficult fractures of the femoral shaft.

South Med J, vol. 51: 642 .

Chapman, M. (1980):

The use of immediate internal fixation in open fractures.

Orthop C1in North Am, val. 11, 3: 579.

Charnley J. (1974):

The closed treatment of common fractures.

Ed.: Church111 Livingstone, Edinburgh.

Commitee on Medical Aspects of Automotive Safety (1971):

Rating the severity of tissue damage.

I. The abbreviated scale.

JAMA, vol. 215, 2: 277 .

Crotwel1, W. (1978):

The thigh lacer: ambulatory non-operative treatment of femoral shaft

fractures.

J Bone Jolnt Surg, vo1. 60A, 1: 112.

Danckwardt-L1111eström, G. (1970):

Intracortical circulation after intramedullary reaming with reduction of pressure in the medullary cavity.

$\mathrm{J}$ Bone Jolnt Surg, vol. 52A, 7: 1390.

Danckwardt-Li11leströin, G. (1973):

Intramedullary nalling of femoral shaft fractures after reaming of the medullary cavity.

Acta Chir Scand, 139: 155. 
Debrunner, A. (1967):

Biomechanische Wirkungen der postraumatischen Achsenfehler der unteren Extremität.

In: Müller, M.: Posttraumatische Achsenfehlstellungen an den unteren Extremitäten.

Ed.: Verlag Hans Huber, Berr.

Dencker, H. (1963):

Fractures of the shaft of the femur.

Ed.: Orstadius Boktryckeri, aktiebolag, Göteborg.

Dencker H. (1964):

Errors in technique and complications specific to intramedullary nafling. Acta Orthop Scand, 35: 164 .

Derweduwen, J. (1979):

A new intramedullary compression device for fractures and pseudarthroses of the long bones.

Acta Orthop Belg, 45: 659.

Dieh1, K. (1976):

Stabliltä und Beanspruchung von Osteosynthesen des Ober- und Unterschenkels bei der Fruihmoblitisation.

Unfal thellkunde, $79: 81$.

Duyn van, C. (1977):

Fracturen van het distale deel van het femur.

Dissertatie, Groningen.

Eden van, P. (1923):

Behand lungserfolge der Oberschenkel schaftbrüche.

Acta Chir Scand, 67: 320.

Eitel, F.; Schenk, R.; Schweiberer, L. (1980):

Corticale Revaskularisierung nach Marknagelung and der Hundetibia.

Unfall heilkunde, 83: 202 .

Ferdie, P.; Scholz, R.; Stampfel, 0.; Zöch, G. (1975):

zur Marknagelung des Oberschenkelshaftbruches bei "relativer Indikation". Arch Orthop Unfallchir, 82: 31 .

Frledenstein, A. (1968):

Induction of bone tissue by transitional eplthellum.

clin Orthop, 59:21.

Gezondheldsraad (1977):

Rapport nr. 50: Richtlijnen ter preventie en bestrijding van zlekenhulsinfectles ( 27 julli 1976$)$.

Ed. : Staatsultgeverif, 's-Gravenhage.

Goris, R. (1982):

Early osteosynthesis and prophylactic mechanicall ventilation in the mulltrauma patient.

J Trauma, vol. $22,11: 895$. 
Gorls, Ro, Draal sma, J " (1982):

Death after blunt injury.

Injury, yol. 14, 1: 7 .

Gorlo, R.; Glmbrere, J.; Niekerk van, J.; Schoots, F.; Booy, L. (1982): Improved survival of multiply injured patients by early internal fixation and prophylacte mechanical ventilation.

Injury, vol. 14, 1: 39.

Gorls, R. (1983):

The injury severity score.

World J Surg, 7: 12 .

Göthman, L. (1960):

The arterial pattern of the rabbit's tibia after the application of an intramedullary nail. A microamgiographic study.

Acta Chir scand, 120: 211.

Göthand L. (1961):

Arterial changes in experimental fractures of the monkey's tibla treated with intramedullary nailing. A microanglographic study.

Acta Chir scand, 121: 56.

Gotzen, L.; Tscherme, H.; Haas, N.; Ennker, J. (1983):

Bilanz der konservativen und operativen Knochenbruchbehandlung untere

Extreml tät.

Chtrurg, $54,4: 234$.

Grosse, A.; Lafforgue, D. ; Weigel, A. (1978):

Zielgeräte zur Verriegelung.

In: Vécsel, V.: Verriegel ung snagelung. Symposiun, Wenen.

Ed.: W. Maudrich Verlag, Wenen.

Hardy, A.; Nicholson, 0. (1976):

Cast brace application and early ambulation as a treatment of femoral shaft fractures.

NZ Med J, 25: 111 .

Hardy, A. (1982):

Shortening and angulation of femoral shaft fractures treated by cast brace application and early ambulation.

Clin Orthop, 168: 139.

Haredy, A. (1983):

The treatment of femoral fractures by cast-brace application and early arabullation.

J Bone Joint Surg, vol. 65A, 1: 56.

Hejnen, J.; Dabbs, G.; Mason, H. (1949):

The experimental production of ectopic cartilage and bone in the muscles of rabbits.

\$ Bone Joint Surg, 31A, 4: 765 .

Helple, K.; Brooks, D.; Samson, B.; Burstein, A. (1979):

A fluted intramedullary rod for subtrochanteric fractures.

J Bone Joint Surg, vol. 61A, 5: 730 . 
Hey Groves, E. (1916):

On moderm methods of treating fractures.

Bd.: John Wright Son, 1td., Bristol.

Hey Groves, E. (1918):

United fractures with special reference to gumshot injuries and the use of bone grafting.

Br J Surg, vol. 6, 22: 203 .

Hildebrandt, G. (1979):

Dile Bedeutung der periossären und intramedullären Durchblutung fuir die

Entstehung der posttraumatisichen osteomyelitis und fü die Wah des osteosyntheseverfahrens.

Beitr Orthop Tramatol, 26 (4): 18 .

Hoglund, E. (1917):

New method of applying autogenous intramedullary bone-transplants and of making autogenous bone-screws.

Surg Gynecol Obstet, 24: 243.

Holden, C. (1972):

The role of blood supply to soft tissue in the healing of diaphyseal

fractures.

$J$ Bone Joint Surg, vol. 54A, 5: 993.

Hoogenband van den, C.; Moppes van, F. (1982):

Diagnostic and therapeutic aspects of inversion trauma of the ankle jolnt. Dissertatie, Mastricht.

Huggins, C. (1.931):

The formation of bone under the influence of epthelium of the urinary

tract.

Arch Surg, 22: 377 .

Huiskes, R.; Janssen, J.; Slooff, T. (1980):

A detalled comparison of experimental and theoretical stress-analyses of a human femur.

In: Mechanical properties of bone - AMD vo1. 45: 211 .

Ed.: S. C. Cowin.

Hunter, S. (1982):

Deformation of femorall intramedullary natls.

Clin Orthop, $171: 83$.

Hutzschenreuter, P.; Perren, 5.; Stelnemann, S.; Geret, V.; Klebl, M. (1969):

Some effects of rigidity of internal fixation on the healing pattern of osteotomies.

Injury, vol. 1, 1:77.

Huw 1 jer, J* (1956):

Die Pseudarthrosen nach Cerclage des Unterschenkelfrakturen.

2 Unfallmed Berufskr, 49: 152.

Informatie "Stichting Medische Registratie" (1974):

Ned Tijdschr Geneeskd, 118: 47. 
Joost van, M.; Gastkenper, R. (1972):

Maltotation after femoral shaft fractures.

Arch Chir Neer1, 24:101.

Jorgensen, T. (1977):

The prevention and treatment of pseudarthrosis in Denmark.

In: Pseudarthrosis and posttraumatic ostertis.

Ed. Dr. G. J. van Hoytema St1chting, Enschede.

Kaessmann, H. (1970):

Die Kompressions Nagelung gebrochener Röhrenknochen.

Disiertatie, Göttingen.

Kember. N. (1960):

Cell division in endochondral ossification.

$J$ Bone Jolnt Surg, vol. 42B, 4: 824 .

Kerpf, I.; Jaeger, J.; WeIge1, A. (1978):

Bionechanische Untersuchungen zur Vertlegelungsnagelung.

In: Vêcsel, V.: Verrlegelungsnagelung. Symposium, Wenen.

Ed.: W. Maudrich Verlag, Wenen.

Kesgler, S.; Rahn, B.; Eitel, F.; Schwelberer, L.; Perren, S. (1983):

Die Blutversorgung der Knochencorticalis nach Marknagelung - Vergleichende Untersuchungen an verschiedenen Tierspecies in vivo.

Hefte Unfallheilkd, 165: 7 .

Kingma, M.; Rogge, C. (1973):

The balanced suspension traction and its history.

Arch Chir Neer1, 25: 245.

KHrschner, M.; Nordmann, 0. (1926):

Die Chirurgie.

Ed.: Urban \& Schwarzenberg, Berlijn.

Klem, K. (1978):

Entwicklung und Behandlungsprinzip der Verriegel ungsnagelung.

In: Vécsei, V.: Verrlegelungsnagelung. Symposium, Wenen.

Ed.: W. Maudrich Verlag, Wenen.

Klopper, P. ( 1981$)$ :

Intrameduliary fixation of experimental femur fractures with plastic rods. Voordracht Instructional course on intranedullary fixation of fractures, Maatricht.

Kootstra, G. (1973):

Femoral shaft fractures in adults.

Ed.: Van Gorcum \& Comp. B.V., Assen.

KosLowski, L.; Weller S. (1962):

Tiicken der Marknagelung.

Chltrurg, 33, 10: 460 .

Koud1, F. (1977):

Die Behandlung der Mehrfachfrakturen am Femur.

Unfall hell kunde, $80: 89$. 
Rrompecher, S. (1956):

Die Reeinflussbarkeit der Gewebsdifferenzierung der granulierende knochenoberflächen insbesondere die der Callusblidung.

Langenbecks Arch Chit, 281: 472 .

Krompecher, S. (1958):

Die qualitative Adaptation der Gewebe.

Z Mikrosk Anat Forsch, 64: 59.

Kummer, B. (1959):

Bauprinzipien des Saugerskeletes.

Ed.: Georg Thieme Verlag, Stuttgart.

Kuntscher, G. (1957):

Das Callusproblem.

Arch Orthop Unfallchir, 49: $l$.

Küntscher, G. (1959):

Die Technik des Aufweitens der Markhöhle.

Chirurg $30,1: 28$.

Küntscher, G. (1967):

Practice of intramedullary nailing.

Ed. : Charles C. Thomas, Springfield.

Lambotte, A. (1913):

Chirurgie opératoires des fractures.

Ed.: Masson et Cie, Parijs.

Lambrinudi, C. (1940):

Intramedullary Kirschner wires in the treatment of fractures.

Proc Soc Med (Orthop), 33: 153.

Lane, W. (1914):

The operative treatment of fractures.

Ed.: The Medical Publishing Co. Itd., Londen.

Léctutier, M.; Smith, A. (1957):

Atr enbolism as a complication of medullary naling.

I Bone Joint Surg, vol. 39B, 3: 534 .

Leeman, R. (1957):

Die "Falzcerclage" al s technische Verbesserung der Drahtumsch11ngung bel.

Brüchen der langen Röhrenknochen.

Chyrurg, 28, 2: 60 .

Lermens, H. (1970):

Stabiele intramedullary osteosynthese.

Ned. Ver. tot bevordering van Chirurgische Wetenschappen, 22 e Congres: 39.

Lemenens, H. (1975):

Intramedullary naling of tiblal fractures.

In: General Surgery, Orthopaedles, Plastilc Surgery - Controversial.

opinions.

Ed.: Excerpta Medica, Amsterdam. 
Lemens, H. (1981):

Peroperative complicatlons of intramedullary nalling.

Voordracht Instructional course on intramedullary flxation of fractures, Matatricht.

Lindahl, $0 .(1962)$ :

Rigldity of immobllization of transverse fractures.

Acta Orthop Scand, $32: 237$.

Lindahl, O. (1964):

Migldity of imobilization of oblique fractures.

Acta orthop scand, 35: 39 .

Loon van, L. (1935):

Historisch overzicht van de fracturbehandeling der lange pijpbeenderen.

Ed." Zomex Keuning Uitg. Mij., Wageningen.

Lottes, J.; Key, J* (1953):

Complications and errors in technic in medullary nailing for fractures of

the femur.

cIin Orthop, 2: 38.

Manten, A.; KIingeren van, B. (1983):

De toepassing wan desinfectantia op de huid.

Geneesmiddelerbulletin, 17, 1: 1 .

Matter, P. (1975):

The effect of static compression and tension on internal remodelling of cortical bone.

Ed.: Schwabe \& Co. Verlag, Basel.

McCoy, S.; Fitzgerald, E.; Johmson, K. (1976):

Fractures conference - cast bracing of femoral fractures.

Minn Med, 1: 58.

McMaster, W.; Prietto C.; Rovner, R. (1980):

Closed treatment of femoral fractures with the fluted sampson

intrameduldary rod.

Orthop Clin North An, vol. 11, 3: 593.

Metz, L. (1904):

De behateling der schuine dijbeenbreuken.

Geneeskundige bladen 103: 217 .

MLller, H.; Dav1s, M.; MacClean, C.; Davis, J*; Smith, B.; Humphries, J. (1983):

Radiation exposure and associated risks to operating-room personnel during use of fluoroscople guldance for selected orthopaedic surgical procedures. J Bone Joint Surg, wol. 65A, 1: 1.

Miller, P.; Welch, M* (1978):

The hazards of tibial pin replacement in 90-90 skeletal traction. clin Orthop, 135: 97. 
Holster, A.; Gjerdet, N.; Alho, A.; Bang, G. (1983):

Fracture healing after rigld intramedullary nalling in rats. Acta Orthop Scand, 54: 366 .

Muiller, M.; Allgöwer, M.; Schneider, R.; Willenegger, H. (1977):

Manual der Osteosynthese - A. O. technik.

Ed.: Springer Verlag, Berlijn.

Nicolaysen, J. (1897):

Describing a mailing technique.

Nord Med Axkiv, 8: 1 .

Oberdalhoff, $\mathbb{H}$. (1947):

Zur frage der knochenbildung.

Chirurg, 17, 3: 123 .

O1sson, O. (1949):

Some cases of nectosis of the bone by encircling suture (cerclage) in oblique fractures.

Acta Chir Scand, 99: 85.

Pankovich, A. (1981):

Adjunctive fixation in flexible intramedullary nalling of femorad.

Eractures.

C1in Orthop, 157: 301.

Pauwels, F. (1951):

Ueber die bedeutung der Bauprinzipien des Stutz- und Bewegungsapparates für die Beanspruchung der Röhrenknochen.

Acta Anat, 12: 207.

Perkins, G. (1958):

Fractures of the shatt of the femur.

Ed.: The Athlone Press.

Perren, S.; Huggler, A.; Russenberger, M.; Allgöwer, 茫. (1969):

The reaction of cortical bone to compression.

In: Cortical bone healing *

Acta Orthop Scand (Supp1), 125: 19.

Pfister, U.; Rahn, B.; Perren, S.; We1ler, S. (1979):

Vaskularität und Knochenumbau nach Marknagelung langer Röhrenknocher.

Aktuel Traumatol, 9: 191.

Pricchard, I. (1972):

General histology of bone and the osteoblast.

In: The biochemistry and physiology of bone.

Ed.: G.H. Bourne, Academic Press, New York.

Rehm, J.; Uebing, D. (1963):

Die Behandlung von Frakturen langer Röhrenknochen mit dem Marknagel nach küntscher.

Arch Orthop Unfallchir, 55: 82. 
Bhimelander, $R \cdot(1968)$ :

The normal microcitculation of diaphyseal cortex and its response to fracture.

J Bone Jolnt Surg, vol. 50A, $4: 784$.

Rhinelander, F. (1973):

Effects of medullary natling on the normal blood supply of diaphyseal cortex.

In: Inatructional course lectures.

Am Ac Orthop Surg, vol. 12: 161.

Ruppstein, J. (1955):

Zux Bestimmung der Antetorsion des Schenkelhalses mittels zweler Röntgenbilder.

z Orthop, 86: 345 .

Riska, E. ; Bonsdorff von, H.; Hakkinen, S.; Jaroma, H.; KIviluoto, O.; Paawlainen, T. (1977):

Primary operative fixation of long bone fractures in patients with multiple 1 injuries.

J Trauma, vol. $17,2: 111$.

Roberts, J. (1977):

Management of fractures and fracture complications of the femoral shaft, usling the ASTF compression plate.

J Trauma, vol. 17, 1: 20 .

Roux, W. (1895):

Gesannelte Abhandlung uber entwicklungsmechanic der Organismen.

Ed.: Wilhelm Engelman, Leipzig, wol. I, II.

Roux, W. (1912):

Anpassung glehre, Histomechanik und Hilstochemie.

Berichtungen $z u$ R. Thomas glelchnamigen Aufsat $z$ mit bemerkungen über die

Entwicklung und Formgestaltung der Gelenke.

Virchaws Arch (Pathol Anat), 209, 168.

Rush, L.; Rush, H. (1939):

A technique for longltudinal pin fixation of certain fractures of the ulna and of the femur.

J Bone Jolnt Surg, vol. 21, 3: 619 .

Sarmtento, A.; Latta, L. (1981):

Closed functional treatment of fractures.

Ed. : Springer Verlag, Berlijnn.

Sauter, A.; Klopper, P. (1983):

Fat embolism after statc and dynamic load.

Acta Orthop Scand, 54:94.

Schatzker, J. (1980):

Open intramedullary nalling of the femur.

Orthop Clln North Am, wol. 11, 3: 623 . 
Schauwecker, $F .(1981)$ :

Osteosynthese praxis.

Ed.: Georg. Thieme Verlag, Stuttgart.

Schenk, R. (1977):

Histologie der Frakturhellung und der Pseudarthrosen. A.0.-Bulletin, 11 .

Schmitz, J." Ahnefeld, F.; Burri, C. (1983):

Nutritional support of the multiple trauma patient.

World J Surg, 7: 132.

Schweiberer, L.; Berg van den, P.; Dambe, L. (1970):

Das Verhalten der intraossären Gefässe nach Osteosynthesen der

frakturierten Tibia des Hundes.

Therapiewoche, $20: 1330$.

Semmlov, J.: Cone, R. (1976):

Utility of the Injury Severity score. A confirmation.

Health Serv Res, 11: 45.

Sevitt, S. (1981):

Bone repair and fracture healing in man.

Ed.: Churchill Livingstone, Edinburgh.

Sinith, H. (1950):

Intramedullary nailing.

$J$ Bone Joint Surg, vol. 32A, 2: 464.

Smith-Petersen, M.; Cave, E.; Vangorder, G. (1931):

Intracapsular fractures of the neck of the fenur.

Arch Surg, vol. 23, 5: 715.

Soeur, R. (1946):

Intramedullary pinning of diaphysial fractures.

$J$ Bome Jolint Surg, vo1. 28, 2: 309 .

Spirig, B. (1967):

Die Diagnose der Achsenfehler der unteren Extrentiat.

In: Mulder, M.: Posttraumatische Achsenfehlstellungen an den unteren

Extremitüten.

Ed.: Verlag Hans Huber, Bern.

Spoelstra, D* (1970):

Dr. Antonius Mathifsen, uitvinder van het gipsverband.

Ed.: Van Gorcum \& Comp. B.V., Assen.

Stapert, J. (1978):

Stabiele intramedullaire osteosynthese van het femur.

Ned Tijdschr Geneeskd, 122, 44: 1732.

Stapert, J.; Greep J. (1979):

Intramedullary compression nall developed by Kaessmann in femoral

fractures.

Woordracht International College of Surgeons, San Franclisco. 
Steinaran, F. (1907):

Elne reue extenston Methoide in der Erakturembehandiung.

Zentralb1 Chir, 34:938.

Stöhrer, M. : Preis, G.; Georg1, P.; Langhoff, J.; Franke, D. (1972): Untersuchungen iiber den Einfluss von Cerclagen auf die Durchblutungsverhall trisse an Hundeknochen.

Langenbecks Arch Chir (Supp1), Chir. Forum: 23.

Stratuen var, T. (1974):

De stablele intramedullaire osteosynthese van het onderbeen.

Een retrospectief onderzoek.

Dissertatie, Amsterdam.

Straten van, T.; Maier, C. (1981):

Blomechanics of Kaessmann nald in osteosynthesis of femur and tibla.

Voordracht Instructional course on intramedullatre flxation of fractures, Mastricht.

Stürmer, $\mathbb{K}$. ( 1980$)$ :

Die Schaftstibia als Tiermodel 1 für die Marknagelung.

Unfallheilkunde, $83: 341,433$.

Ta11lard, W. (1976):

1"Osteosynthése differée des fractures diaphysaires du femur chez

I'adulte.

Rev Chir Orthop, 62: 309.

Tonna, E.; Cronkite, E. (1962):

Changes in the skeletal cell prolfferatie response to trauma concomitant wh th agling.

J Bone Jo1nt Surg, vol. 44A, 8: 1557.

Tordoir, B.; Moeys, E. (1945):

The treatment of certain types of fractures with $V_{2}$ A steel nad1 in the medullary cavity. The Küntscher method.

JAMA, wa1. $128,11: 792$.

Trueta, J.; Cavad1as, A. (1955):

Vascular changes caused by the Kuntscher type of nailing.

An experimental study in the rabbit.

J Bone Jolnt Surg, vol. 37B, 3: 492.

Trueta, J. (1962):

A theory of bone formation.

Acta Orthop Scand, 32: 190.

Truetal , J.; Cavad1as, A. (1964):

A study of the blood supply of the long bones.

Surg Gynecol Obstet, vol. 118, 3: 485 .

Tscherne, $\mathrm{H} .(1977)$ :

Operationstechuik und Ergebnisse bel Mehrfragment und Trümerbruchen des Femurschaftes.

Unfall the 11kunde, $80: 221$. 
Tscherne, H.; Oestern, H.; Sturm, J. (1983):

Osteosynthesis of major fractures in polytrauma.

World J Surg, 7: 80.

Whthoff, H.; Einnegan, M. (1983):

The effects of metal plates on post-traumatic remodeling and bone mass. $J$ Bone Joint Surg, vol. 65B, 1: 66 .

Urist, M. (1965):

Bone: formation by autoinduction.

Science, 150: 893 .

Urist, M.; Strates, B. (1970):

Bone formation in implants of partially and wholly demineralized bone matrix. Including observations on acetone-fixed intra and extracellular protelins.

C1in Orthop, 71: 271 .

Urist, M*; Iwata, H.; Boyd, S.; Ceccott1, P. (1974):

Observations implicating an extracellular enzymic mechanism of control of bone morphogenesis.

J Histochem Cytochem, vol. 22, 2: 88 .

Vecse1, V. (1978):

Verrlegelungsnagel ung. Symposium, Wenen.

Ed.: W. Maudrich Verlag, Wenen.

Wang, G.; Dunstan, J.; Reger, S.; Hubbard, S.; Dillich, J.; Stamp, W. (1981):

Experimental femoral fracture immobllized by rigid and flexible rods (a rabbit model).

Clin Orthop, $154: 286$.

Watson-Jones, R. (1950):

Medullary nalling of fractures after fifty years.

J Bone Joint Surg, vol. 32B, 4: 694 .

Watson-Jones, R. (1976):

Fractures and joint injurles.

Ed.: Churchill Livingstone, Edinburgh.

Weber, B.; Cech, O. (1973):

Pseudarthrosen, Pathophysiologie, Blomechanik, Therapie, Ergebnisse.

Ed.: Verlag Hans Huber, Bern.

Weller, S.; Renné, J. (1973):

Grundsätzliche fehler und Komplikationsmöglichketten der Marknagelung.

Chiturg, 44, 12: 79 .

Weller, S.; Kuner, E.; Schweikert, C. (1979):

Medullary nalling according to Swiss study group princtples.

C1in orthop, 138: 45 . 
Weller, S. (1983):

Tatramedullary nalling of fetur and tibla.

In: Current problems in fracture treatment IV (from shaft to shaft).

Gi.: Dr. G.J. van Hoytema Stlchting, Enschede.

WLeser, C. (1963):

DLe primäre Knochenbruchhellung und thre Stärung im Röntgenbild.

Largenbecks Arch Chir, 308: 434.

W1 lenberg van den, (1982):

Free revascularized autologous periosteun transplantations.

Dissertatie, Mi jmegen.

Winant, E. (1949):

The use of skeletal traction in the treatment of fractures of the femur. J Bone Jolnt Surg, vol. 3lA, 1: 87 .

Winquist, R. ; Hansen, S. (1980):

Commuted fractures of the femoral shaft treated by intramedullary nalling.

Orthop Clin Worth Am, vol. 11, 3: 633 .

Whter, G.; Sperling, M.; Steinhäusser, M. (1978):

Erhennung und Behand lung traumatischer Gefassverletzungen im kniegelenksnahen Bereich.

Diseh Med Wochenschr, 103: 786. 


\section{Dankwoord}

Dit proefschrift is totstandgekomen door de lnzet van velen. Ledereen die hierbij behulpzaam is geweest, dank lik van harte.

Tijdens mifn opleiding tot algemeen chirurg was het Dr. F.J.M. Voorhuls, te Enschede, die mij met de grondbeginselen van de fracturbehandellng liet kenuis maken.

Prof. Dr. H.A.J. Lemmens maakte mij vertrouwd met de indicatiestelling en operatletechniek, warmee de patiënten beschreven in dit proefschrift, zifn behandeld. Als grondlegger wan de intramedullatre osteosynthese $\ln ^{\prime}$ Wederland en als co-promotor, leverde hil een belangrijke bljdrage aan het totstandkomen van deze studie.

Zeer veel dank ben $1 \mathrm{k}$ verschuldigd aan Prof. Dr. J.M. Greep, de drijvende kracht achter deze studie, die veel tijd besteed heeft aan het totstandkomen van dit werkstuk.

Het grote enthouslasme voor de tramatologie blijkt ook uit de bewonderenswardige inzet van Prof. Dr. R.J.A. Goris, die met het kritisch lezen van dit proefschrift een grote bijdrage heeft geleverd.

Dok Prof. Drs. B. Binnendijk en Prof. Dr. A.J. van der Linden, ben lk dankbaar voor hun commentaar als referenten.

De tijd die nodig was om deze studie op schrlft te stellen kor voor een belangrifk deel gevonden worden, doordat mijn collegae stafleden en artsassistenten een groot deel van mijn werk in de kliniek hebben verricht. Dit geldt in het bijzonder voor cees Rein van den Hoogenband en Koen Oosterhuis.

Er zijn zelden twee paranymfen geweest, die daadwerkelijk inhoudelifk zoveel aan een proefschrift hebben bijgedragen, Paul Jörning met zijn scherpe kritische commentaren warvan hij het gehele manuscript voorzlen heef en Hillem Stapert samen met Marijke Stapert-Eggen, die het manuscript zoveel mogelijk gezuiverd hebben van Nederlandse taalfouten.

Dok mijn vader, Harry Stapert, gaf met vele deskundige opwerkingen richting aan dit werkstuk.

Chris Voskamp maakte met zeer veel inzet en naukeurigheld de 11lustatles, die een speciale kleur aan het geheel hebben gegeven.

$B i j$ het oproepen en verwerken van de patlëntengegevens waren Ingrid Sti1le-Gielen, Gerda Haemers en Nicole Castermans-Biesmans van onschatbare waarde. Lilianne Erven-Amory verzamelde de literatuur.

Het medisch archief, onder leiding van Dhr. M. Marres, was behulpzaan bij het opzoeken wan de patiëntengegevens.

Het is echter Luuk Beckers-Jussen geweest die als steun en toeverlabt, corrigerend, opnieuw beginnend, uit stapels chaotioche papieren het manuscript heeft samengesteld. Zonder haar bijdrage zou dit proefschrift noolt voltooid zijn.

Niet onwermeld mag blijven dat Daphne, Sven, Mirjan en vooral Marfe-Anne een grote hoeveel held extra geduld getoond hebben in de laatate fase van de totstandkoming van dit werkstuk. 


\section{Curriculum vitae}

Jowwert Stapert merd geboxen op 19 jull 1941 te st. Odilienberg. In 1960 behalde hij het elndexamen HBS-b aan het Bernardinus College te: Heerlen. Hif studeerde geneeskunde aan de medische faculteit van de KathoIleke Universitelt te Nijmegen, war hig in 1969 zifn artsexamen behaalde. Van september 1970 tot november 1970 volgde hij de tropencursus aan het Koninkl1jk Institult voor de Tropen te Amsterdam. December 1970 vertrok hij naar Tanzania, war hij in het Chunya district tot 1973 functioneerde als district medical of 1 cer in het Mambani District Hospital.

Van 1973 tot 1979 volgde hij zijn opleiding tot chirurg aan de afdeling Algemene Heelkunde van Ziekenhuis St. Anmadal te Maastricht (Hoofd tot 1976: Prof. Dr. H.A.J. Lemmens, na 1976: Prof. Dr. J.M. Greep).

Van 1979 tot 1981 verwude hif de functie van chef de clinique en sinds 1 Januarl 1981 makt hij deel uit van de vaste staf van de capaciteitsgroep Algemene Heelkunde van Zlekenhuis St. Annadal te Mastricht, war hij special belast is met de medische zorg voor ongevalspatienten. 
Druk: Schrijen-Lippertz B.W., Voerendaa1.

Graflsche vormgeving en illustratie: Chris Voskamp

Het verschijnen van dit proefschrift werd mede mogelijk gemaakt door steun van:

Laméris Instrumenten B.V., Utrecht

Orthomed B.V. medische techniek, Schiedam

West Chyrurgische Instrumenten B.V., Bilthoven 